Diana Paola Gómez Mateus

QUANTO DURA O TERROR?

A NARRATIVA DA VIOLÊNCIA EM DOIS FILMES COLOMBIANOS

São Paulo

2012 
Universidade de São Paulo

Faculdade de Filosofia, Letras e Ciências Humanas

Departamento de Antropologia

Programa de Pós-Graduação em Antropologia Social

\section{Dissertação de Mestrado}

QUANTO DURA O TERROR?

A NARRATIVA DA VIOLÊNCIA EM DOIS FILMES COLOMBIANOS

Aluna: Diana Paola Gómez Mateus

No. USP: 7261745

Orientadora: Profa. Dra. Rose Satiko Gitirana Hikiji

Dissertação apresentada ao Programa de Pós-

Graduação em Antropologia Social do

Departamento de Antropologia da Faculdade de

Filosofia, Letras e Ciências Humanas da

Universidade de São Paulo, como requisito parcial para a obtenção do título de Mestre em

Antropologia.

São Paulo 


\section{Catalogação-na-publicação \\ Biblioteca Florestan Fernandes da FFLCH-USP}

GÓMEZ Mateus, Diana Paola

Quanto dura o terror? A narrativa da violência em dois filmes colombianos Orientação Profa. Dra. Rose Satiko Gitirana Hikiji. São Paulo, 2012 159f

Dissertação de Mestrado apresentada ao Programa de Pós-Graduação em Antropologia Social do Departamento de Antropologia da Faculdade de Filosofia, Letras e Ciências Humanas da Universidade de São Paulo.

1. Antropologia do cinema. 2. Cinema colombiano. 3.Experiência. 4. Narrativa do terror. 
Diana Paola Gómez Mateus

Quanto dura o terror? A narrativa da violência em dois filmes colombianos.

Dissertação de mestrado apresentada ao Programa de Pós-Graduação em Antropologia Social do Departamento de Antropologia da Faculdade de Filosofia, Letras e Ciências Humanas da Universidade de São Paulo, como requisito parcial para a obtenção do título de Mestre em Antropologia.

Aprovado em:

São Paulo,

Banca examinadora

Nome:

Instituição:

Julgamento:

Assinatura:

Nome:

Instituição:

Julgamento:

Assinatura:

Nome:

Instituição:

Julgamento:

Assinatura: 


\section{Agradecimentos}

A Rose Satiko Gitirana Hikiji, orientadora generosa, que com rigor e dedicação me animou neste projeto de vida e de pesquisa.

A CAPES, Coordenação de Aperfeiçoamento de Pessoal de Ensino Superior pelo financiamento desta pesquisa.

Ao Departamento de Antropologia e ao Programa de Pós-Graduação em Antropologia Social da USP.

Ao Prof. Dr. John C. Dawsey e Prof. Dr. Eduardo Morettin pelas excelentes contribuições no exame de qualificação.

Aos professores que com suas aulas inspiraram temas da pesquisa, Júlio Assis Simões, Renato Sztutman, Beatriz Perrone-Moisés, Ismail Xavier, Esther Imperio Hamburger e Sylvia Caiuby Novaes. Àqueles que leram o projeto e discutiram a proposta em diferentes momentos, César Augusto Ayala, Magdalena Peñuela Uricoechea e, especialmente a Myriam Jimeno que realizou uma leitura crítica do texto e orientou o desenvolvimento do mesmo.

Aos colegas do Grupo de Antropologia Visual (GRAVI), do Núcleo de Antropologia da Performance e do Drama (NAPEDRA), do Núcleo de Antropologia do Direito (NADIR) e do Núcleo de Antropologia Urbana (NAU) pelo apoio, leituras, debates e desvios.

Ao Grupo de Etnologia Indígena (GEU-NAU), José Agnello Andrade, Yuri Bassichetto Tambucci, Flávia Belletati e Ana Sertã e ao Professor Dr. José Guilherme Cantor Magnani pela experiência de produção do vídeo Memorial Indígena que me permitiu explorar o campo da realização audiovisual.

Aos colegas do grupo de orientados de Rose Satiko Gitirana Hikiji, pois suas leituras e comentários enriqueceram o trabalho de escrita.

Às Comissões Editoriais da Revista Cadernos de Campo, pelos excelentes anos de trabalho.

A Ciro Guerra e Vassilis Stathoulopoulos, pelos filmes! Pela atenção recebida durante as entrevistas.

A Bruna Triana que, perspicaz e carinhosa, leu e revisou cada uma das linhas desta pesquisa. A ela devo um agradecimento especial pela dedicação com este trabalho, pelas ideias inteligentes e pelas tardes de cinefilia.

A Camila Mainardi, Denise Pimenta e Ana Fiori, pela leitura crítica e atenciosa, os comentários e as sugestões instigantes e eloquentes.

A Enrico Spaggiari, Kelen Pessuto e Rosenilton Oliveira, sem cuja ajuda este texto seria ilegível. 
A Corporación Cultural El Barco, pelos anos de cinefilia na cidade de Bogotá.

A Marina Barbosa, Milena Estorniolo, Raphael Sabaini, Michele Escoura, Rodrigo Chiquetto, Leonardo Bertolossi, Ana Flávia Bádue, Claudia M. Quijano, Alejandra Rada, Jaime Orjuela, Enrique Ramírez e Anderson Borba, pela amizade e apoio, tão importante quando se está longe da terra natal.

A Tatiana Mendoza, Lorena Suárez, Adriana Marcela Gómez, amigas e irmã sem cuja presença, palavras, fotografias e conversações esta viagem não teria sido possível.

A Maia e sua família, Henry A. Cruz, Tatiana Meza, Juan Pablo Pinto M., Fernando López Vega e Héctor García Botero pelos filmes, os reclamos e as discussões. A Beto Villada e ao teatro Varasanta pelas perguntas instigantes, ainda sem resposta, e pelas as encenações de um país que sente e sofre, que dança e luta, que cria e resiste.

A Luz e Wolfram Krieger, pelo apoio e por me impulsionarem a caminhar neste caminho.

Aos meus pais, Belkyz Mateus e Fernando Gómez pelo carinho e apoio, sem cujos conselhos e amor este projeto não teria sido realizado.

A família, sempre presente, alegrando cada um dos meus dias.

E a quem embora não tenha sido citado nesta pequena lista, coloriu esta dissertação com perguntas, comentários, conversações, passeios, imagens, risos e companhia.

Diana Paola Gómez Mateus 


\section{Resumo}

O foco desta dissertação é a construção narrativa audiovisual da violência. A partir de discussões feitas na antropologia sobre narrativa, mimesis e violência se quer pensar a respeito de formas de narrar a experiência da violência política e o conflito armado colombiano. O objeto que será analisado são filmes colombianos, dois especificamente: $L a$ sombra del caminante (Ciro Guerra, 2004) e PVC-1 (Spiros Stathoulopoulos, 2007). Obras audiovisuais que se apropriam da tecnologia digital e fazem uso criativo dos recursos cinematográficos para se colocar diante das imagens sobre violência e discutir temas como a verdade e a memória, o tempo e o medo, o intimo e do cotidiano. São formas fílmicas que instigam uma discussão sobre as narrações que a sociedade colombiana constrói para contar o terror de décadas de violência política e conflito armado onde atores à margem da lei, sociedade civil e governo se encontram e se constroem.

O procedimento metodológico empregado nesta dissertação é, em um primeiro momento, o da análise fílmica, um modelo teórico definido no campo dos estudos de cinema, que propõe um estudo do filme nos seus múltiplos componentes e atendendo aos espaços e dinâmicas nas quais este se insere. Deste modo, em um segundo momento, indagarei a propósito das narrativas do terror, sendo o terror ato, espaço e cultura, uma situação que se torna estável pela instabilidade que o caracteriza: a experiência da violência, da perda (de parentes, de um lugar de origem, de um passado), do deslocamento forçado, da tortura. Esta é uma tentativa de pensar sobre a mediação do cinema para comunicar efetivamente tal experiência de terror, um fenômeno cuja narração se coloca nas margens do dizível. Neste sentido, o cinema articularia o inarticulável e narraria o inenarrável, incorporando experiências do terror na memória coletiva.

\section{Palavras chave}

Antropologia do cinema, cinema colombiano, experiência, narrativa do terror. 


\section{Resumen}

El objetivo de esta disertación es la construcción narrativa audiovisual de la violencia. A partir de las discusiones realizadas en la antropología sobre narrativa, mimesis y violencia se pretende pensar sobre las formas de narrar la experiencia de la violencia política y del conflicto armado colombiano. El objeto de estudio son filmes colombianos, dos específicamente: La sombra del caminante (Ciro Guerra, 2004) e PVC-1 (Spiros Stathoulopoulos, 2007). Audiovisuales que se apropian de la tecnología digital y utilizan creativamente los recursos cinematográficos para posicionarse frente a las imágenes de la violencia y discutir temas como la verdad y la memoria, el tiempo y el miedo, lo cotidiano y lo intimo. Son obras que instigan una discusión sobre las narraciones que la sociedad colombiana construye para contar el terror de décadas de violencia política y conflicto armado donde actores al margen de la ley, sociedad civil y gobierno se encuentran y se construyen.

El procedimiento metodológico empleado en esta disertación es en un primer momento, el del análisis fílmico. Un modelo teórico definido en el campo de los estudios de cine, que propone un estudio de los múltiplos componentes del filme, atendiendo a los espacios y dinámicas en los que este juega algún papel. En seguida, indagaré a propósito de las narrativas del terror, siendo el terror acto, espacio y cultura, una situación que se estabiliza gracias a la inestabilidad que lo caracteriza: la experiencia de la violencia, de la pérdida (de familiares, de un lugar de origen, de un pasado), del desplazamiento forzado, de la tortura.

Este es un intento de pensar sobre la mediación del cine para comunicar efectivamente tal experiencia de terror, un fenómeno cuya narración se encuentra en las márgenes del habla. En este sentido, el cine articularía lo inarticulable y narraría lo inenarrable, incorporando la experiencia del terror en la memoria colectiva.

\section{Palabras clave}

Antropología del cine, cine colombiano, experiencia, narrativas del terror. 


\begin{abstract}
This dissertation's main focus is the audiovisual narrative construction of violence. Taking account of the anthropological debates on narrative, mimesis and violence; I pretend to think about the ways in which the experience of the Colombian political violence and armed conflict is narrated. The object are Colombian films, two mainly, La sombra del caminante (Ciro Guerra, 2004) and PVC-1 (Spiros Stathoulopoulos, 2007). Films, which use digital technology and implement creatively cinematographic resources to take place before images of violence and discuss topics such as truth and memory, time and fear, the everyday and the intimate. These are oeuvres that instigate a debate about the narratives that the Colombian society elaborates to tell the terror of decades of political violence and armed conflict where actors at the margins of law, civil society and govern meet and build themselves.

The methodological procedure employed in this dissertation is in a first moment, film analysis. A theoretical model defined in the area of cinema studies which proposes a study of the film's multiple components and the many ways and places in which a film plays part. Thus, in a second moment, I'll inquire about narratives of terror, being that terror is an act, a space and a culture, a situation that stabilizes itself thanks to its instability: the experience of violence, of loss (of relatives, of a place of origin, of a past), of forced displacement, of torture.

This is a proposal to think about the mediation of cinema to communicate effectively such experiences of terror, a phenomenon whose narration is on the margins of the speakable. In this sense, cinema would articulate and narrate what is not; and would introduce the experiences of terror in the collective memory.
\end{abstract}

\title{
Keywords
}

Anthropology of cinema, Colombian cinema, experience, narratives of terror. 


\section{Sumário}

\section{Introdução}

Os materiais para a construção 12

1. Notas sobre cinema colombiano 26

2. Cinema quadro a quadro e com elipses 29

\section{Capítulo I}

Sombra do passado, sombra do presente

\section{Capítulo II}

Quanto dura o terror? 95

1. Plano-sequência

2. O espectador na tela

3. O conhecimento venenoso

Imagens da tortura e os limites do mostrável

4. Rewind

Reflexão sobre o tempo nervoso

\section{Considerações finais}

Aftermath

(balanço, ponderação, sequela...) 
Introdução

Os materiais da construção 
À noite, um homem bate à porta. Outro abre, surpreso, e olha para o homem que foi visitá-lo, um sujeito grave, de óculos redondos e pretos. O visitante que descobre seus sentimentos de amizade, sente-se obrigado a contar um segredo. No quarto do anfitrião, o visitante abre uma caixa preta, ela contém uma fita de VHS. Como não há um aparelho de televisão no quarto, vão no aposento da dona da pensão. Ali na escuridão e em silêncio, o dois assistem à única prova que existe do passado infame deste sujeito estranho (La sombra del caminante, Ciro Guerra, 2004).

Após a invasão, os xingamentos e os golpes, o silêncio invade a sala da casa. As crianças no chão, pés e mãos atados, silenciadas com um pano na boca. O homem ajoelhado, com as mãos atadas nas costas e a mulher com um artefato no pescoço que se parece com um colar feito de tubos de PVC. Pouco a pouco voltam a respirar e a falar, se abraçam e choram. O homem descobre uma fita cassete em um bolso preto, tenta reproduzi-la no aparelho de som, mas este não funciona, procura, então, o gravador portátil da filha. Escutam a ameaça dos invasores e tomam conhecimento de que o colar é uma bomba (PVC1, Spiros Stathoulopoulos, 2007)

Duas fitas, uma que libera o segredo de um passado silenciado e outra que agride o presente. Dois filmes e duas formas de contar e mostrar a dor, experiências de sofrimento e de medo. São mediações narrativas e audiovisuais do terror, um caminho possível para pensar a respeito da violência. Um caminho que é também um desvio, uma lente para observar o mundo ou, enfim, uma imagem que faz ver e conhecer a partir de um certo enfoque. Portanto, é distanciamento e exigência de encontrar ou redefinir palavras para estudar e escrever sobre o sofrimento causado pela violência.

As indagações pessoais em torno da violência na Colômbia, meu país, me levaram a estudar relatos de vítimas produzidos por um programa de televisão, durante a graduação na Universidad de los Andes (Bogotá). A preocupação me levou a estudar as questões ligadas à imagem, o visível e o invisível, as estratégias narrativas e a construção da memória do conflito. Com algumas questões na cabeça e uma mochila de $10 \mathrm{~kg}$ nas costas, cheguei em São Paulo no ano de 2009 com o propósito de realizar na Universidade de São Paulo o mestrado em Antropologia Social. E se entrar na Universidade foi um processo difícil, depois entendi que seria o começo de um trabalho complicado: me distanciar do meu país e de seus 
problemas para, precisamente, falar do país e de seus problemas. Um distanciamento físico e climático [das montanhas andinas e do frio às terras baixas e quentes do Brasil], linguístico e cultural: como falar sobre um assunto que não é conhecido nos seus detalhes e não utilizar o repertório de palavras e imagens do senso comum para facilitar o processo de comunicação? Como traduzir, do espanhol ao português, palavras e sentidos que me eram familiares e que começavam a revelar o quanto eu não sabia, o quanto eu tinha normalizado uma história que utilizava referências, metáforas e explicações já feitas óbvias pelo seu uso excessivo e sem reflexão? A partir desse momento, falar da violência na Colômbia, exigia mais do que estudar os textos históricos, sociológicos, antropológicos, ou mesmo, econômicos, pois o primeiro problema a resolver era de vocabulário, para poder realizar um trabalho de crítica e tradução, de estranhar o cotidiano, de questionar o familiar e de dês-objetivar a violência.

Estudar filmes no contexto do mestrado, a partir de elementos da análise fílmica e em diálogo com as teorias antropológicas, foi o caminho que escolhi para abordar questões que tinham surgido no meu trabalho anterior e enfrentar o desafio proposto. Uma estratégia inspirada no meu trabalho no Cineclube El Barco, na cidade de Bogotá, porque lá durante cinco anos de exibições e debates, vi como as pessoas que assistiam às sessões partiam dos filmes para falar sobre o país, a notícia do dia ou questões históricas e até íntimas relativas à violência. O mais interessante é que o filme, independente de sua nacionalidade, às vezes era uma metáfora, outras era uma premonição ou, inclusive, uma proposta de solução ao presente, que nos mostrava situações complexas, difíceis de entender e que, por vezes, nos entristeciam. Os filmes despertavam reações nas pessoas, isto me motivou a estudar seriamente a imagem e sua relação com narração e memória. Os filmes como caminhos e desvios, aproximações e distanciamentos necessários para que, como diria Taussig (1986), o terror não se volte contra nós.

O foco desta dissertação é a construção audiovisual e narrativa da violência. O objetivo é pensar a propósito de uma forma específica (a fílmica) de narrar uma experiência (a da violência política colombiana), para refletir sobre as consequências, elaborações, transformações e influências do conflito armado colombiano na elaboração de narrativas do terror, as formas de feitura da verdade e da cultura (Taussig, 1986). O trabalho se propõe a ser uma contribuição à pesquisa sobre o conflito colombiano, a partir de uma perspectiva que une 
antropologia e cinema, uma vez que o problema reclama a atenção de uma variedade de perspectivas para dar conta da interação da multiplicidade de agentes e eventos que decidem o presente e o desenvolvimento desse processo. É também um trabalho que dialoga com a discussão da antropologia visual, em particular no que toca à construção do cinema de ficção como objeto de pesquisa da antropologia e à discussão de categorias como experiência e memória na sua relação com a imagem.

A questão principal será abordada a partir da análise de dois filmes colombianos, a saber: La sombra del caminante do diretor Ciro Guerra, lançado em 2004, e o filme PVC-1, dirigido por Spiros Stathoulopoulos, lançado no ano de 2007 nos Estados Unidos e em 2008 na Colômbia ${ }^{1}$. Estes filmes, as primeiras obras dos diretores, foram produzidos de forma independente - sem apoio do estado nem da empresa privada - e circularam em importantes festivais internacionais, como o de La Habana em Cuba, San Sebastián na Espanha, Cannes ${ }^{2}$ na França e o de Tessalônica na Grécia. A despeito do entusiasmo manifestado pela crítica de cinema publicada em jornais, entre eles o de maior circulação no país, El Tiempo, os filmes tiveram um público muito pequeno (uma média de sete mil espectadores, segundo informações obtidas no site de Proimagenes ${ }^{3}$ ). A crítica especializada de cinema (textos publicados principalmente na Revista Kinetoscopio ${ }^{4}$ ) avaliou estes filmes como sendo obras de autor, caminhos possíveis para uma cinematografia colombiana ${ }^{5}$, e com propostas estéticas

1 Em entrevista com o produtor executivo do filme, Vassilis Stathoulopoulos, realizada na cidade de Bogotá no dia 20 de janeiro de 2011, foi discutido este assunto. O produtor afirmou que esta foi uma decisão comercial, para impedir a venda imediata do filme em circuitos piratas.

2 Os filmes colombianos tem tido uma pequena participação no Festival de Cannes desde 1964, ano da apresentação do curta-metragem de Francisco Norden, Las murallas de Cartagena. Depois, em 1984, o longa-metragem de Norden, Cóndores no entierran todos los dias, participou na seleção de Un certain regard. Em 1990, o longa-metragem Rodrigo D, no futuro participou da seleção de filmes em competição; em 1998, outro filme, La vendedora de Rosas, do mesmo diretor, participou na seleção de competição. Outros curtas-metragens e coproduções colombianas participaram do Festival. Ver web site oficial do Festival: http://www.festival-cannes.fr Acessado em 02/2012.

3 No web site Proimagenes, a entidade encarregada de lidar com o cinema na Colômbia, consta que no ano de 2005 foram produzidos 9 filmes com um total de 1.979.106 espectadores de cinema colombiano: La sombra del caminante teve 7.834 espectadores; Rosario Tijeras, do diretor Emilio Mallé, teve o maior número de espectadores, com 1.053.030. No ano de 2008, quando foi lançado o filme $P V C-1$, o qual teve 6.860 espectadores, foram lançados 14 filmes colombianos e houve um total de 2.217 .753 espectadores de cinema colombiano. Isto a partir de um levantamento feito nas principais cidades: Barranquilla, Bogotá, Cali e Medellín, sendo que a cidade de Bogotá é a que mais com bilheteria. Para mais informações ver: www.proimagenes.com.co. Acessado em 02/2012.

4 Kinetoscopio é uma revista editada pelo centro Colombo Americano de Medellín. É a publicação periódica atual mais importante da Colômbia em matéria de cinema.

5 O nascimento da "cinematografia colombiana" tem sido decretado toda vez que algum filme tem boa bilheteria, favorável acolhida em festivais ou é importante para a crítica. Mas é um momento que não tem continuidade. Muitos diretores afirmam que é tão difícil fazer o segundo filme quanto o primeiro, porque sempre se começa do zero. Assim, apesar de bons filmes serem lançados por vezes simultaneamente, não vemos uma produção consolidada. 
consistentes em meio aos filmes sobre drogas e corrupção, imagens típicas do cinema feito na Colômbia. Esta resposta ao filme de Ciro Guerra é importante de ressaltar, pois este foi um trabalho realizado quando o diretor ainda era estudante de cinema na Universidad Nacional de Bogotá. A equipe é composta pelos colegas de estudo do diretor; apenas os atores, que vêm do teatro, e o produtor, Jaime Osório, que participa da montagem final do filme, não pertencem ao mundo estudantil. Diferentemente, o filme de Spiros, foi realizado com um interesse de ser exibido e distribuído comercialmente e em importantes festivais de cinema.

Neste trabalho, os filmes não serão estudados a partir da perspectiva do consumo, da indústria do cinema, mas sim como produtos de uma cultura, uma sociedade e uma história. $\mathrm{O}$ que motiva tal posição é a ideia de que os filmes instigam uma discussão importante sobre as formas que a sociedade colombiana utiliza para se narrar, para contar o terror de mais de cinco décadas de violência política e conflito armado onde atores armados à margem da lei, sociedade civil e governo se encontram e se elaboram.

Primeiramente, a denominação "violência política", utilizada para identificar a situação colombiana, precisa ser esclarecida, ainda que brevemente. Segundo Melo (1998), essa violência não é o resultado de uma única força, mas sim produto de uma série muito complexa de elementos difíceis de identificar e isolar,

Ideologizações e justificações, de estratégias ou formas de se exercer, de instrumentações ou de organizações ad hoc para exercê-la [...] Um elevado número de manifestações: motins, greves, rebelião, insurreição, revolução, repressão, golpe de Estado, etc. Um elevado número de maneiras de se exercer: resistência, luta armada, guerrilha, terrorismo, ação de milícia urbana, controle social, perseguição policial, e para alguns ou vários teóricos pertencem a este mesmo gênero de fenômenos as guerras, os diversos tipos de guerras. Há múltiplas instrumentações: células, bandas, organizações guerrilheiras, seitas, organizações paramilitares de partido, corpos policiais, exércitos (Aróstegui 1994, p. 37, tradução minha ${ }^{6}$, grifos no original).

São muitos os nomes dados às ações violentas e aos diversos atores, porém nenhum deles resume a complexidade do fenômeno, ainda que assinale, para cada caso, algumas das suas características. As guerrilhas foram assim definidas por Palacios (2001):

A guerrilha colombiana combina uma ideologia marxista-leninista, uma

6 Todas as traduções deste trabalho são minhas. 
concepção jacobina da política (em duas versões, a versão estalinista e agrariana das FARC e a guevarista da pequena burguesia universitária do ELN) e uma concepção autoritária da sociedade e do Estado, com as tradições clientelistas próprias da cultura camponesa e as percepções subjetivas de exclusão social de jovens rurais e camponeses, reforçados recentemente pela sua capacidade de inserção nas economias da coca e da papoula (ibid., p. 34, tradução minha).

De acordo com o sociólogo francês Daniel Pécaut (1987), as FARC-EP configuram-se como um ator coletivo, não uma simples força criminosa. Um ator político que nasce no contexto das lutas campesinas e das demandas pela reforma agrária (Gott, 1970) e propõe discussões sobre a ordem do Estado colombiano; considera-se a si mesma uma força do povo colombiano que entende suas demandas e luta pela sua libertação.

São várias as análises sobre a guerrilha e suas transformações em mais de quatro décadas de existência (Pécaut, 2010). Ela teve suas origens em 1964, mas é em 1966 que se articula a um projeto político orientado à conquista do poder (Pizarro, 1989). A partir desse momento começa uma atuação típica de "guerra de guerrilhas", na qual violência e atos políticos são realizados de forma simultânea. O recurso ao financiamento do narcotráfico (Echandía, 2000) mudou o cenário do conflito e se intensificaram as operações violentas (Rabasa e Chalk, 2001). Hoje em dia, após uma violenta campanha militar liderada pelo presidente Uribe Vélez, as guerrilhas encontram-se diminuídas (Pizarro, 2005), porém sua existência não está em questão, e ainda sob a premissa da luta agrária se fazem visíveis no campo político por meio de comunicados ${ }^{8}$, sequestros e ataques a povoados e infraestrutura. Vale a pena mencionar que no ano de 2012, o atual presidente colombiano Juan Manuel Santos, graças à intervenção de vários setores da população e organizações de direitos humanos e com a participação de Cuba e Venezuela, retoma o processo de negociação.

À estratégia insurgente se opõe uma contrainsurgente ${ }^{9}$, liderada pelos grupos paramilitares ${ }^{10}$. Estes estão organizados à margem das forças militares com o objetivo de guardar a ordem e a segurança das elites econômicas e políticas (Franco, 2009). Surgem, em

7 Uma descrição detalhada desta forma de operação encontra-se no livro "La guerra de guerrillas", de Ernesto Che Guevara, publicado em Cuba no ano de 1960. Em geral, baseia-se em uma organização de grupos pequenos, comandados por uma estrutura central, com o uso técnicas móveis (invasão, ambushes, etc.) e de surpresa. Cria-se um estado de incerteza no inimigo e precisa de uma estrutura de base que apoie os combatentes, tanto em simpatia como em materiais para a guerra (armas, roupas, etc) e abrigo (Guevara, 1960).

8 Os comunicados, assim como a história e material audiovisuais, fotográfico e sonoro das FARC, estão disponíveis no web site oficial da guerrilha: www.farc-ep.co. Acessado em 08/2012.

9 Existe um arquivo com um grande número de referências bibliográficas sobre a teoria contrainsurgente no site: http://wikileaks.org/wiki/Counterinsurgency. Acessado em 08/2012.

10 Para uma caracterização das forças paramilitares colombianas ver, Quijano (2010). 
parte, como uma forma de preencher os vazios estratégicos que as forças militares não conseguiam atender para atacar as guerrilhas e se fortalecem durante os processos de negociação de paz que começam durante o governo do presidente Virgilio Barco (1986-1990) e se estendem até o governo do presidente Andrés Pastrana (1998-2002), como uma forma de protesto contra tais processos (Gonzáles et al, 2002). Os paramilitares, organizados sob o nome AUC (Autodefensas Unidas de Colombia), se estabilizaram em 1997 após a separação desta facção das ACCU (Autodefensas Campesinas de Córdoba y Urabá), mas esse tipo de estrutura existia no país desde a década de 1980, com os grupos MAS (Muerte a Secuestradores), com algumas diferenças. Os paramilitares são "grupos armados organizados para realizar operações de limpeza política e consolidação militar, anteriores ao domínio de uma área" (Romero, 2003, p. 38); enquanto as estruturas que os precederam eram denominadas autodefesas: "agrupações organizadas para se defender de um agressor e manter o controle de um território, sem pretensões de expansão" (Loc, cit.). Hoje em dia se tem demonstrado que as AUC têm vínculos com estruturas de governo, configurando assim o que se chama de "parapolítica" (ibid.).

Por vezes esta violência parece datar de tempos muito antigos, como se cada nova configuração fosse só uma atualização de um tipo de violência original; esta visão pessimista contrasta com outra, que afirma a existência de violências cada uma com condições específicas; o que não exclui a questão de ser um conflito muito antigo e alimentado por motivos políticos (Camacho, 1990). Uma primeira manifestação de violência organizada é a chamada La Violencia, entre os anos 1945 e 1965, caracterizada por ser um enfrentamento entre as elites em nome de partidos políticos e que em algumas regiões teve expressões ligadas ao vandalismo e ao banditismo de grupos adstritos a setores sociais que operaram ações para efetuar a exclusão dos outros (Sánchez, 2004). Esta oposição binária fechou as portas a manifestações políticas alternativas e expressões de "tolerância política pensados a partir do poder" (Ayala, 1996, p. 46) o que impediu ao Estado de reconhecer as diferenças e estabeleceu uma situação de conflito permanente (Op. cit.).

A violência contemporânea, identificada já na década de $1960^{11}$, pode ser entendida como a de uma guerra irregular (Franco, 2009) que é descrita em cinco pontos principais

11 Nesta década o líder camponês de esquerda, Manuel Marulanda Vélez (Tirofijo), organiza um grupo de pessoas sob o nome de FARC (Fuerzas Armadas Revolucionarias de Colombia) e define como modo de operação o de guerrilha, configurando assim a forma contemporânea da violência no país (Gott 1970, Gonzáles et. al 2002). 
(Thompson apud Franco, 2009, p. 500): 1) não envolve unicamente o uso da força; 2) as operações de combate não são a característica principal; 3) o objetivo das partes é ganhar a simpatia da população civil; 4) cada conflito é diferente e requer um conjunto de procedimentos operacionais; e 5) as atividades paramilitares estão ligadas às considerações políticas, sendo as forças militares menos importantes. Para além desta descrição, o sociólogo francês Pécaut (1987, 1997 e 2010) afirma que esta lógica de violência é a forma pela qual o Estado colombiano tem se construído, sendo a outra cara da ordem - e não a sua contraposição.

Esta breve descrição e análise sobre o contexto da violência política colombiana não poderia deixar de lado a questão do narcotráfico, cujo papel central para a economia colombiana faz deste negócio uma atividade que marcou o desenvolvimento de políticas de governo nos últimos anos, assim como definiu a natureza da relação da Colômbia com os Estados Unidos, a União Europeia e os países vizinhos. Thoumi (2002) identifica três momentos no desenvolvimento do narcotráfico. O primeiro começou na metade da década de 1960 com a produção e venda de maconha; uma estrutura relativamente simples que na década de 1970 decaiu para dar lugar à produção de cocaína, um negócio mais rentável do que o da maconha. Foi nesta época que se desenvolveram e fortaleceram os grandes cartéis da droga e que o lucro atingiu a economia do país, elevando-a. A partir de 1986 o cultivo da coca partilhou território com o da papoula, sem que o último atingisse negativamente o primeiro. A economia do narcotráfico gerou tantos ganhos como perdas e hoje vemos as consequências disto no âmbito social: pobreza, violência e criminalidade nas cidades; e na política: financiamento de campanhas presidenciais, assassinato de líderes políticos.

Diversas perspectivas e análises concordam com a ideia de que a longa duração desse conflito e as diversas manifestações que têm tido ao longo do seu desenvolvimento contribuíram à construção de uma narrativa nacional onde prevalece a presença da violência não só como pano de fundo de outras questões, mas como a própria narrativa (Jaramillo, 2007). Geoffrey Kantaris (2008) faz uma periodização do cinema colombiano, segundo a qual os filmes produzidos nessas etapas acompanham, ressaltam, ecoam e até criticam o momento histórico - sublinhando a violência - no qual estes estariam sendo produzidos. Michael Taussig (1986) afirma que as sessões de yagé no Putumayo colombiano são, em vários sentidos, formas de se apropriar da memória do terror produzido pelos distintos momentos de violência (a colônia, a economia da borracha, o conflito armado) na região, e de inseri-la em 
uma estrutura por meio da qual as pessoas construiriam formas de viver no presente. Esta elaboração de narrativas para explicar as irrupções da violência na vida cotidiana, utilizam elementos de diversas origens muitas vezes verdadeiros exemplos de montagem, como mostra o trabalho de Alejandro Castillejo (2005) sobre o deslocamento forçado. O antropólogo argumenta que as testemunhas das vítimas da violência de deslocamento forçado na Colômbia marcam o "antes" e o "depois" do evento, estabelecendo uma relação de "passado bom", "presente ruim" através da organização dos distintos momentos do deslocamento e o uso de "metáforas do mal" para qualificar os agentes da violência e identificar os motivos desses atos.

No desenvolvimento do trabalho, a questão da elaboração fílmica da violência será pensada a partir da ideia de narrativa, entendida aqui como uma construção possível da realidade, ou seja, o filme é pensado como uma proposta de realidade, que ilumina espaços, permite leituras e abordagens, e que desembocaria em visões renovadas do cotidiano. Tal aproximação será explorada em duas partes: a primeira, a partir do filme La sombra del caminante e a segunda a partir do filme $P V C$-1. O primeiro filme conta uma história de pessoas que, por causa da violência, são obrigadas a se deslocar do campo à cidade e lá se tornam seres marginais que deambulam pelas ruas de Bogotá. O filme faz um convite a repensar o que se tem por certo sobre o tema do deslocamento forçado e a pobreza na Colômbia, por meio de procedimentos estéticos e narrativos que permitem rever as ruas da cidade e seus habitantes, e, sobretudo, apresenta personagens complexos e absurdos, impossíveis, mas verossímeis.

La sombra del caminante apresenta duas personagens que se encontram na capital colombiana e criam uma relação de ajuda e amizade, marcada pelo silêncio e por um passado que não é possível esquecer nem ignorar, mas que não pode ser dito se não em momentos e espaços especiais. Filmado na cidade de Bogotá no ano de 2002, mostra uma cidade fria e agressiva, porém poética e lugar de chegada e encontro de tantas pessoas e histórias diferentes.

A segunda parte tratará do filme $P V C$-1, que coloca a questão do tempo em perspectiva. 
Partindo da ideia de que um filme é uma elaboração possível da realidade, este pode não só mostrar personagens ou paisagens, mas elaborar o tempo. A montagem é a forma pela qual o tempo fílmico é produzido, muitas vezes com o intuito de fazer dele uma imitação do tempo real. Já $P V C-1$ é um filme feito em um único plano-sequência (ou seja, sem cortes), que aqui elabora o tempo íntimo. A discussão que o filme propõe é sobre a narração do tempo nervoso, aquele que é desconhecido, irrepresentável, a duração do terror. Se o filme não é um convite à reflexão, é uma obra que obriga o espectador a sentir o medo alheio.

PVC-1 narra a história de extorsão que sofre a família de Ofelia, uma mulher do campo, esposa de Simón e mãe de duas filhas e um filho. Para forçar o pagamento de uma soma exorbitante de dinheiro, a família é ameaçada com um colar bomba que é colocado no pescoço de Ofelia. A intervenção do Estado é inútil e a bomba explode. Com este filme em plano-sequência (sem cortes), Spiros Stathoulopoulos apresenta uma elaboração dramática do tempo e se propõe um desafio técnico importante. O longa põe em cena um fato real, bem conhecido na Colômbia graças às imagens de jornalistas que foram publicadas em jornais e revistas no ano de 2002. Porém, a análise não irá debater a questão da verossimilhança desta representação ${ }^{12}$; o foco é a construção narrativa e audiovisual do filme de um evento dramático.

Este é um trabalho que se propõe a pensar com o filme, deixar o filme ocupar o lugar principal e não o lugar de ilustração, comentário ou representação, de permitir que o filme seja entendido de forma complexa e não reduzido a uma história. Não será abordado o tema da recepção, ou seja, a compreensão do que acontece depois da projeção do filme, com o tempo, na sua circulação e exibição. $O$ foco do trabalho é a experiência que o filme oferece e a atenção é sobre os filmes em si. Portanto, no procedimento metodológico serão utilizadas algumas das ferramentas de análise discutidas por pesquisadoras e pesquisadores, teóricos e diretores de cinema. Principalmente na linha de Jacques Aumont (1983, 1988, 1996, 1998), um estudioso francês de cinema que tem se perguntado como, porquê e qual o objetivo da análise fílmica, produzindo assim uma proposta coerente que atende as questões estéticas e interpretativas dos filmes.

Aumont (1988) defende uma posição segundo a qual analisar um filme é dissociar a

12 Este é um termo problemático. Eu o utilizarei no sentido mais amplo de formas de reprodução, sendo privilegiados os termos de elaboração ou construção no sentido de processos criativos que dão lugar a uma imagem. Na maioria das citações que trago à discussão aparece a palavra representação, de forma ambígua, algumas vezes como reprodução, outras como elaboração criativa. 
forma fílmica ${ }^{13}$ da história contada; um processo sistemático, crítico e cinéfilo que tem como objetivo mostrar os elementos fundamentais da construção do filme e aproximá-los dos discursos sobre cinema. Desta forma, a análise parte da solução a certo problema fílmico que oferece a imagem, sendo que a imagem é entendida como algo que "diz", que "significa" por ela mesma e não como um lugar onde os sinais de uma enciclopédia qualquer podem ser identificados (Aumont, 1996). De modo que a reflexão sobre a experiência que o filme oferece seguirá estes aspectos: a elaboração de uma situação que pode ser qualificada como inenarrável, a desfiguração para pensar a expressão de uma verdade, a tatilidade do olhar, o rosto, a identificação e a interpelação do espectador pela imagem na tela, a questão do tempo sensível e a elaboração do medo pelo filme.

Outro componente digno de atenção é a diegese, ou seja, tudo que diz respeito ao filme, o mundo real do filme. $\mathrm{O}$ termo indica que existe uma espacialidade e uma temporalidade próprias ao filme, que permite uma variedade (limitada e virtual) de posturas, posições, atitudes, comportamentos e relações entre as personagens e destas com o ambiente (Aumont, 1988). É um mundo que "faz sentido" em si mesmo, um tipo de realidade elaborada com materiais fílmicos. É um termo que serve para pensar o lugar que o espectador pode ocupar dentro do filme e se colocar em relação a ele. Por outro lado, a diegese pode ser pensada como a história que o espectador conta depois de assistir o filme, aquilo que permaneceu na memória, unido ao que poderia ser chamado de uma primeira interpretação dessas imagens. Isto porque quem narra situa-se diante das imagens, organiza-as, comenta-as. $\mathrm{Ou}$, em outras palavras, é a descrição do filme, o que, segundo Aumont, é o passo inicial da análise fílmica. Pode-se dizer que é o mundo do filme na tela e na cabeça do espectador. Aquele mundo das linhas em cursiva deste trabalho. Trata-se da posição de antropóloga-espectadora que ocuparei nesta pesquisa, uma forma específica de reescrever e explicar os elementos dos filmes, como afirma Hikiji (1998).

Neste mundo diegético o espectador é inserido, suas emoções são atingidas e modeladas. Aumont (1983) pesquisador-espectador, afirma que a forma de encenação dos objetos é um convite à reflexão sobre o imaginário da realidade e a realidade da imagem, pensar sobre a presença vivida (diante a tela) e a ausência real (do que está na tela). O interesse é, sobretudo, pelos espaços que a imagem constrói para interpelar o intelecto e as

13 Por forma fílmica entende-se o elemento estruturante da forma cinematográfica, de sua gramática de base. Pode ser uma operação técnica ou plástica, sempre está acompanhada de determinações e significações. O close- up, o travelling, a voz off, são formas fílmicas. É o que dá forma à matéria-prima do cinema, a luz. 
emoções do espectador, como, por exemplo, o uso dos olhares, dos rostos e do tempo articulados e elaborados por meio de um tipo de montagem. Elementos que modelam uma série de associações para a plateia. Ou, segundo Ismail Xavier ([1983] 2003), um tipo de experiência que o cinema oferece: atraente pela imagem e o som, a imagem mobiliza afetos e é "instância de celebração de valores e reconhecimentos ideológicos mais talvez do que manifestação de consciência crítica" (ibid., p. 10). Surgem duas perguntas: que tipo de associações podemos nos permitir diante de um filme? Que tipo de experiência La sombra del caminante oferece? Qual é a proposta de experiência de $P V C-1$ ?

Em outro plano, a análise pode refletir sobre o contexto que produziu o filme e as condições materiais e psicológicas que este modela e que são aceitas socialmente. Um trabalho que tem por objetivo formar o público, a crítica, a cinefilia e aproximar a análise dos discursos sobre cinema (Aumont, 1988). Neste sentido, a leitura de crítica de cinema em livros e revistas, assim como de reflexões sobre cinema colombiano, é fundamental para estabelecer um panorama diante do qual posso me posicionar como pesquisadora e entender os filmes que são o objeto de estudo. Não se trata de estabelecer uma "história do cinema colombiano" ou uma "análise da crítica cinematográfica colombiana". É um ponto de partida - que elaborarei em breve - para me aproximar dos filmes e uma referência permanente para não perder de vista o campo no qual se inserem os filmes aqui analisados. Os demais assuntos referentes à produção do filme, como mercado, custos de produção ou bilheteria, não serão abordados, se não tangencialmente.

Além disso, a análise ainda apresenta algumas ferramentas para considerar a capacidade de invenção da imagem, sua força de significar, de criar, de expressar, fazer pensar e conceber o valor da imagem no processo pelo qual ela volta ao mundo e o reflete de forma distinta, o multiplica ou até o imagina. Imagem que não é natural e nem espelho; é resultado de uma elaboração intelectual e plástica que tem a capacidade de devolver olhares diferentes sobre o real. Enfim, uma forma de se apropriar do visível que impõe uma resposta sensorial e intelectual (Aumont, 1996) e que, concomitantemente, é uma forma cuja organização da imagem/som diz respeito a objetivos socioculturais do momento em que é produzido um filme (Xavier, 2005). Desta forma podemos já repensar o cinema colombiano, qualificado por alguns críticos (ver Osório, 2010) como essencialmente violento ou que só mostra a violência, porque o país é violento. 
Cada análise fílmica responde a todos ou a alguns destes objetivos, e seus resultados dependem inteiramente do filme, já que é o ponto de partida e o horizonte. De modo que não existe uma metodologia definida e sim caminhos possíveis para desenvolver tal análise. Sendo também uma forma de escrita ou de transcrição, de deslocamento - no sentido de que é uma passagem do visual para o escrito - este trabalho permite pensar no problema da escrita na antropologia, das possíveis soluções para dar conta de uma dimensão alheia ao texto: a multiplicidade plástica do filme. É também um desafio de produção de interpretações pertinentes e pontos de vista renovadores e instigantes sobre a obra sem, portanto, impor sentidos, nem reduzir o filme à história narrada ou tentar um exercício de transcrição literal. Trata-se de observar, decompor e recompor o filme de forma que os problemas que a obra coloca e os interesses da pesquisa se encontrem no texto (Vanoye e Goliot-Leté [1992] 1994).

Apesar da análise fílmica poder ser um fim em si mesmo, neste trabalho ela é o procedimento pelo qual indagarei a propósito das narrativas do terror. O terror, no sentido descrito por Michael Taussig (1986), é um estado social e fisiológico que serve para mediar as relações entre diferentes grupos sociais na modernidade. É a maneira pela qual objetivos práticos (por exemplo, a organização da mão de obra) são realizados e é uma forma de dominação que mantém a hegemonia. Ato, espaço, cultura; o terror se refere a uma situação que se torna estável pela própria instabilidade que o caracteriza, pois ao não ser unicamente uma coisa material (armas, corpos) nem uma situação específica (guerra, tortura), só é reconhecido em certos instantes nas suas manifestações e consequências e pelas palavras de quem o experimentou (ou, pela apropriação/circulação estratégica destas palavras), criando desta maneira ordem e dominação pelo medo. Ruptura e excesso de significado que se esconde nas aproximações que o imitam (certo tipo de jornalismo) tanto quanto naquelas que pretendem racionalizá-lo (estatística ou análises normativas). De modo que o autor chama a atenção sobre a mediação do terror pela narrativa, ou, em outras palavras, a elaboração do terror em narrativas (literatura, fotografia, filmes ou jornais) a partir das palavras e imagens de quem tem tido a experiência do terror e decide contá-la. Narrativa que organiza, articula, circula e faz conhecer o terror.

Os dois filmes que aqui interessam elaboram um tipo particular de narrativa do terror na Colômbia. Dois elementos elaboram esta questão: narrativa e mimesis. O primeiro se relaciona com as formas de comunicar e intercambiar experiências e construir histórias coletivas, o segundo com o tipo de conhecimento que surge da imitação e do contato. Os dois 
estão vinculados ao campo audiovisual, no sentido de que a narrativa pode ser considerada como a organização particular dos recursos fílmicos e literários que é um filme, e a qualidade mimética se relaciona com a natureza de registro do real da imagem fílmica, cuja visualização põe em contato o aquém (espectador na sala de cinema ou na sala de casa) com o além (as imagens na tela, desconhecidas, novas, longínquas no tempo e no espaço). Então, o propósito de entender o tipo de experiência que o filme oferece vai em direção ao conhecimento de algumas das narrativas do terror que estão sendo elaboradas pelo cinema colombiano contemporâneo para pensar as formas de narrar, os limites da narração e os problemas que coloca a experiência dramática tanto à expressão como à descrição e à análise.

A questão da narrativa é um tema complexo e muito discutido pelas disciplinas sociais e humanas. Assim sendo, especificarei o uso do termo no trabalho. Walter Benjamin ([1936] 2010) considera que a narrativa é uma forma de comunicar que tem a faculdade de intercambiar experiências e construir narrações coletivas; uma forma que se diferencia da informação porque não lida com dados e fatos, pelo contrário, a narrativa não explica, é livre para interpretar a história e com isso, atingir amplitude e atualidade. O narrador, ao narrar, arranca o ouvinte do seu lugar, faz com que ele se esqueça de si mesmo, entre em contato com o narrado e adquira o dom de narrar. Em termos específicos ao audiovisual, podemos pensar em diegese, elaboração do mundo real que surge do exercício de articular elementos próprios ao relato e ao fílmico. E que permite pensar, como afirma Arias (2010), que a dimensão política do cinema se encontra na elaboração do espaço do possível e não apenas na representação de fatos, personagens ou eventos políticos. A narrativa fílmica como uma elaboração de uma realidade possível onde o contato com o outro e a experiência do desconhecido (o terror) é viável (é proposta, desencadeada, animada, alimentada).

Vale a pena insistir na questão do contato, ou, antes, da mimesis. A faculdade mimética é explorada por Michael Taussig (1993) para refletir a propósito da nossa capacidade de imitar e criar modelos, fundamental ao conhecimento e à naturalização das identidades. A cópia mimética tem o poder e o caráter do original, uma imitação que é compulsão por tornar-se outro. União que sutura a natureza e o palpável, e executa a conexão do corpo de quem percebe com aquilo que é percebido para distanciar e liberar. A capacidade mimética envolve o processo histórico de justapor o antigo e o novo que dá poder sobre o que é copiado e leva dentro a alteridade, graças à tarefa de possessão assim efetuada. Este fenômeno é interessante hoje devido ao interesse no conhecimento sensível, um tipo de aprendizagem que, pela 
aderência à pele das coisas por meio da copia realista, desconcerta.

A faculdade mimética é uma forma de organizar o mundo, de se relacionar com ele, darlhe sentido. As câmeras, aparelhos miméticos modernos, renovam e radicalizam esta faculdade. $\mathrm{O}$ uso da câmera (o cinematógrafo) a favor do narrativo (cinema), entendido a partir desta perspectiva, indica a apropriação do visível e sua organização segundo as leis da montagem. Para o filósofo alemão Walter Benjamin ([1935/1936] 2010) este processo poderia chegar a liberar o olhar dos limites do espaço de vida humano, porque the apresentaria dimensões desconhecidas do mundo cotidiano e exercitaria o espectador nas novas formas de percepção. Como as personagens de Ciro, que são verossímeis e absurdos, ou o tempo "irreal" de Stathoulopoulos, que mostra o sentimento no momento de crise. Neste sentido, a câmera transforma o exterior em seu objeto e o oferece ao olhar para ser incorporado nessa nova forma de percepção e na qual o cinema educa a visão humana. A agência da câmera e do cinema para tal liberação e renovação não será tema de discussão no presente trabalho, o que interessa explorar aqui é a organização do visível e do invisível pelo cinema.

A imagem é cópia do original, forma radical de mimesis, efetuada por aparelhos miméticos, que como tal detém o poder e o caráter do original - não porque seja idêntica de fato, mas porque ela é produto de um processo entendido como reprodutor de cópias fiéis. Oferece-se ao olhar e satisfaz desejos de observação e apropriação, não da sua matéria (a fotografia), mas daquilo de que é uma imagem. Não sendo suficiente, a imagem em movimento não só oferece uma imagem de alguma coisa, oferece seu movimento (uma mimesis do seu movimento), oferece o poder sobre a vida do objeto da imagem ao mesmo tempo em que se propõe a atingir a percepção do espectador. Se aceitarmos esta ideia de cópia e contato para pensar a imagem em movimento do cinema, podemos começar a indagar a propósito dos filmes que serão objeto deste trabalho em relação às questões da experiência que eles oferecem no sentido específico da narrativa do terror. $\mathrm{O}$ que acontece quando a imagem nos põe em contato com o terror? E quando ela propõe um contato com esse desconhecido e quase ausente universo da dor?

Taussig convida a pensar nas narrativas do terror como agentes na construção do próprio terror. Nós conhecemos o terror por meio da narração (todo tipo de narração) e o cinema nos dá imagens para pensar no terror; nos fornece rostos, lugares, nomes que identificam e participam do processo mais amplo de construção do discurso e da história do 
terror $^{14}$. A tarefa é revisar as formas de produção de verdade e do medo, sendo que o problema não é o que é permitido dizer, mas as formas de discurso e contradiscurso adotadas. Taussig (1999) chama a atenção para a necessidade de adotar uma nova poética da destruição e da revelação, porque o problema não é simplesmente de desconstrução (no sentido de demolir para criar de novo). O projeto que o antropólogo propõe é o de escrever contra o terror; procurar um discurso que não continue o trabalho da cultura do terror.

\section{Notas Sobre o Cinema Colombiano}

Não querendo relatar aqui os detalhes da história do cinema colombiano ${ }^{15}$ apresentarei alguns momentos importantes para entender seu desenvolvimento. Principalmente com o objetivo de estabelecer um quadro onde possam ser localizados os filmes que serão analisados neste trabalho. Pretendo estabelecer alguns pontos para entender o filme em relação, e não como uma obra isolada cujo valor provém unicamente do aspecto técnico ou formal. Para pôr em perspectiva as obras fílmicas de 2004 e 2007 que analisarei, estas se apreciam por serem independentes na produção, encenação e na própria narrativa escolhida. Uma independência que, para os dois diretores, decorre da produção sem o apoio dos fundos estatais e/ou privados para a produção cinematográfica ${ }^{16}$ (o que significa fundos pessoais e prêmios concedidos por festivais e fundos internacionais). Esta posição está vinculada ao desenvolvimento da tecnologia digital e à relação destes diretores com a arte cinematográfica e do cinema colombiano: diretores jovens, apenas entrando no disputado campo da produção audiovisual, com desejo de realizar suas ideias e estórias em imagens, produção com equipes compostas de

14 Xavier (2005) afirma que cada estética, cada teoria de cinema, é uma idealização sobre o que o cinema deve ser em cada época. Este dever-ser do cinema muda de acordo com a história. A essência e a natureza do cinema são pensadas em termos das ideias predominantes em cada momento. Imagens nem são produzidas autonomamente pela mente criativa do autor nem são postas em circulação de formas inusitadas que modifiquem radicalmente o que se pensa. Trata-se melhor de processos que acontecem simultaneamente, modificando-se perpetuamente.

15 O debate sobre a ausência de "História de cine colombiano" data da década de 1970. Naquela época a crescente preocupação pela produção foi acompanhada pela publicação de algumas obras e artigos, porém esta história escrita é marcada por vazios. Esta pesquisa adere à ideia de pesquisar nosso cinema a partir de pontos de vista múltiplos e tomando como sua particularidade aquilo que é tido como seu próprio obstáculo, como indica Martínez (1978).

16 Proimágenes en Movimiento é a parte do Ministério de Cultura Colombiano que se encarrega de administrar os fundos destinados à produção cinematográfica no país. Para mais informações sobre este órgão, acessar o site: http://www.mincultura.gov.co/index.phpidcategoria=1154?. Acessado em 08/ 2010. 
amigos e outros estudantes de cinema e com o uso dos aparelhos disponíveis.

O jornalista Oswaldo Osório ${ }^{17}$, que tem escrito sobre cinema colombiano, afirma que na historiografia deste cinema há muitos vazios, porque esta não tem acompanhado o ritmo de produção de filmes e que se baseia na crítica publicada em jornais e revistas ${ }^{18}$. Martínez (1978) estabelece uma cronologia e descreve os estilos de cada crítico de cinema até os anos 1980. Segundo Martínez, a primeira crítica era inspirada na literatura e no teatro, ressaltava elementos de argumento, atuação e decoração e ignorava os elementos propriamente cinematográficos (Luis David Peña, Jorge Bernal e Lupecar). O grupo que continuou com esta tarefa observou os elementos técnicos (publicaram sob o pseudônimo de Olimac, Ulises), e paulatinamente o crítico foi aperfeiçoando seu trabalho (Andrés Caicedo, Luis Ospina, Augusto Bernal). Hoje contamos com alguns estudos sobre cinema produzidos no marco de eventos como a VII cátedra Anual de Historia Ernesto Restrepo Tirado, realizada no ano de 2007 ou como resultados de estudos de pós-graduação (Suarez, 2009; Arias, 2010) e ainda, reflexões publicadas com ajuda do Ministério de Cultura colombiano (Arboleda e Osório D., 2003; López, 2006), ou com ajuda de Universidades (Calle, 2002; Osório, 2005 e 2010) graças a editais de publicação de ensaios críticos. Nota-se um crescente interesse no cinema, tanto por pessoas que estudam e produzem cinema como por pessoas de outras disciplinas, como a história, a antropologia e a filosofia. Além do apoio das universidades que agora estes estudos recebem, é notável que o XIV Congreso de Antropología, Proceso de construcción de la nación colombiana, realizado em 2012, tenha se interessado pelo assunto, dedicando o grupo de trabalho Interpretando la nación: Colombia a través del cine ao encontro e discussão do cinema na sua relação com a construção da nação colombiana.

Arte e nação, uma relação antiga tanto harmoniosa como conflituosa. Sergei Einsestein, Leni Riefenstahl, D. W. Griffith são nomes chaves para pensar nos vínculos, causas e consequências da produção de formas fílmicas em concordância com ideologias nacionais. No Brasil, Glauber Rocha é um dos diretores que procurou ajustar produção de cinema e discussão crítica sobre o país, uma produção em película e em texto, não só para apoiar ideias, mas com o intuito de subverter e repensar as que já existiam. Na Colômbia, Carlos Mayolo e Luis Ospina produziram filmes que misturavam elementos da cultura popular e do

17 Autor do web site cinefagos, o jornalista publica críticas, artigos e entrevistas sobre cinema nacional e internacional, e mantém um acervo de documentos sobre cinema colombiano. É uma das referências para pensar a crítica colombiana de cinema hoje. Ver: www.cinefagos.net.

18 Para uma lista completa dos periódicos sobre cinema colombiano (ver Ministério de Cultura et al, 2007). 
documentário crítico para refletir sobre a imagem que se produz sobre a Colômbia e propor olhares divergentes. Em todos os casos, existe uma preocupação pela produção de cinema e o que pode/deve ser mostrado sobre a nação: assim, ideias de "identidade coletiva", "história e geografia comum", “cultura cinematográfica", são articuladas na formação de uma cinematografia que construa a nação pela promoção das paisagens e pela reflexão crítica sobre dinâmicas, processos e problemas.

Neste contexto ressalto a exposição ;Acción! Cine en Colombia, realizada no Museu Nacional de Colombia, com sede em Bogotá, entre outubro de 2007 e janeiro de 2008. Foi um esforço para reunir uma série de objetos, nomes e imagens da cinematografia colombiana e mostrá-los a um público diverso. A exposição foi enquadrada pela ideia de que a "cinematografia contribui ao fortalecimento dos elementos de uma identidade coletiva. As imagens constituem, portanto, um componente de transição da sociedade do conhecimento a uma sociedade das experiências. [...] O cinema é um mecanismo privilegiado que nos sensibiliza acerca da realidade, sobretudo quando requeremos mais solidariedade e de consciência acerca do impacto dos processos sociais, políticos e econômicos que vivemos todos os dias" (Ministerio de Cultura et. al, 2007, p. ix, tradução minha, grifos meus). O que leva a pensar na forma em que segmentos do Estado estão entendendo o cinema, as ações administrativas empreendidas e os espaços abertos para o encontro de pessoas relacionadas com a produção e crítica de cinema e destes e suas obras com um público amplo. Sugere também que as pessoas, estudantes de cinema ou não, estão se expressando na linguagem audiovisual, e mostra que existe um crescimento de pesquisadores e cineclubes que fazem circular obras e ideias sobre cinema, principalmente nas cidades.

Este panorama mostra que existe uma certa atividade no campo do cinema, o que não quer dizer que seja um campo constituído por regras e dinâmicas estabelecidas ou sedimentadas fortemente na história. É um campo recente e exige aproximações que deem conta deste movimento e que o vinculem a outros saberes para olhar a riqueza de propostas e de formas críticas de fazer cinema, pensar na própria produção de imagens hoje na Colômbia e refletir sobre o lugar do cinema diante e inserido no contexto de um país complexo, com dinâmicas de guerra, pobreza e exclusão, com processos culturais, sociais e políticos multiformes e com uma grande necessidade de olhar para si e rever suas histórias para contálas. 


\section{Cinema quadro a quadro e com elipses}

Três obras reúnem artigos e resenhas publicadas entre 1920 e 1980 em volumes: Historia del cine colombiano de Hernando Martínez Pardo, publicada em 1978; Reportaje crítico al cine colombiano, escrito por Umberto Valverde em 1978; e Crónicas de cine colombiano, uma coleção de ensaios de Hernando Valencia Goelkel, publicada em 1974. Nas décadas seguintes há uma explosão de revistas e coletâneas de artigos. Notáveis são Páginas de cine de Luis Alberto Álvarez (1988), e Ojo al cine de Andrés Caicedo (2009). O livro Crónicas del cine colombiano 1897- 1950, de Hernando Salcedo Silva (1981), é uma coleção de 9 entrevistas com realizadores de cinema importantes nos primeiros anos desta indústria no país. A obra de Carlos Alvarez (1989), Sobre cine colombiano y latinoamericano, é um esforço admirável de comparação das cinematografias dos países da América Latina realizada a partir de 1955 até 1980. Uma visão ampla que lhe permite identificar e entender as propostas e caminhos da cinematografia colombiana em relação à brasileira, à argentina e à mexicana.

Hoje, a melhor referência em crítica de cinema é a revista Kinetoscopio editada pelo Centro Colombo Americano de Medellín. Esta maneira de estudar e de escrever sobre cinema pode ser lida como um tipo de relação entre o público e o cinema (diretores, equipe técnica, indústria no geral e, claro, os filmes) que vai mudando com o tempo, as condições sociais e políticas. Assim, estas obras e artigos constituirão um corpus de referências para descrever o panorama de cinema colombiano e dar alguns guias de leitura para entender melhor o lugar que La sombra del caminante e PVC-1 ocupam. Este lugar foi também alimentado por duas entrevistas realizadas no ano de 2011 na cidade de Bogotá: a primeira junto ao diretor Ciro Guerra e a segunda com o produtor Vassilis Stathoulopoulos ${ }^{19}$. Nas duas entrevistas perguntei sobre a origem da ideia e do processo de produção, o porquê da estética elaborada e como os dois veem suas obras em relação ao cinema e ao público colombiano. E, finalmente, li o roteiro do filme La sombra del caminante, como um exercício para chamar a atenção aos detalhes da encenação, muitos dos quais teriam passado desapercebidos. Não tive acesso ao

19 As entrevistas e declarações dos diretores não são tidas como a verdade do filme, do seu objetivo ou propósito. O filme tem suas próprias significações, jogos de sentido e formas de se relacionar com o espectador, assim como formas que independem do diretor de circular e de ser recebido. Porém, o enunciado pelos diretores ilumina a própria percepção do filme, a informa e lhe dá um ponto de referência que pode ser aceito ou não, criticado ou até contraditado. 
roteiro de $P V C-1$, em parte porque segundo o produtor este não existia, pois a filmagem foi planejada em mapas de deslocamentos e posições de câmera, desenhos que ele não possuía.

Martínez Pardo, em sua obra de 1978, descreve a história do cinema colombiano a partir de 1900 até 1976. O historiador estabelece que "dado que o que acontece com o cinema não é independente do que acontece ao nível social, na análise estabeleço a relação entre o mundo do nosso cinema e a dinâmica ou organização que está se apresentando na sociedade, entre o que precisa o cinema para se desenvolver como indústria e para cumprir sua função social como arte e o que as circunstâncias e condições do país oferecem" (Martínez, 1978, p. 16, tradução minha). Ele propõe um tipo de análise a partir das distintas afirmações que têm sido feitas para explicá-lo: a ausência de leis, a questão econômica, o afastamento do cinema da realidade local colombiana, os obstáculos impostos pela indústria da distribuição e da exibição de filmes, a dominação comercial e ideológica do cinema estrangeiro, em paralelo com os filmes, empresas e demais agentes que na história marcaram seu percurso. Esta proposta de entender o cinema em relação aos assuntos sociais e políticos faz desta uma obra fundamental para se aproximar da produção colombiana, dos seus trajetos e desvios.

Martínez estabelece uma historiografia que começa vinculada ao sobrenome Di Domenico, dois irmãos italianos que chegaram a Bogotá em 1908 ou 1909 - não há certeza da data - com alguns filmes e uma filmadora Pathé. Algum tempo depois, em 1920, os Acevedo criariam a primeira empresa produtora de filmes e de noticiários que funcionou até 1955, data do último filme produzido. Em 1912, o Teatro Olympia, primeiro dedicado totalmente à exibição de filmes, abria suas portas a um público curioso pelas imagens em movimento. Situado no centro da cidade de Bogotá, tinha capacidade para 5 mil pessoas, que pagavam um ou outro preço dependendo do lugar que ocupavam na sala: diante ou atrás da tela. Em 1920, a projeção de cinema ocupava um lugar importante entre as atividades de lazer na capital colombiana e foi nesta época que começaram as discussões sobre investimento e apoio do governo à produção de cinema. Dentre as repostas e propostas oferecidas abriu-se o debate sobre a moralidade do cinema e as consequências de uma ou outra produção no comportamento das pessoas, o que fez com que o apoio e a censura fossem realizados simultaneamente.

Surgem novas produtoras (Calvo Films, Ducrane, Patria Films, Cofilma), filmes são 
feitos, novos equipamentos chegam ao país e o interesse pelo cinema nacional cresce até que novas desilusões apagam as luzes do estúdio para que, tempo depois, a película comece a rodar outra vez. Sua história está marcada pelo desenvolvimento do cinema sonoro, invenção tecnológica que afetou o curso do cinema no mundo ${ }^{20}$. Em 1937, a produtora Colombia Films, criada com o ideal de produzir filmes de qualidade europeia e sonoros, realizou uma série de noticiários e documentários no marco do projeto de "Cultura popular" do Ministério de Educação do Ministro Jorge Eliécer Gaitán ${ }^{21}$, demonstrando assim uma colaboração frutífera entre o governo e as empresas produtoras de filmes. O partido liberal esteve sempre a favor da produção cinematográfica nacional por motivos políticos e impulsionado por uma vontade de educação e cultura popular. Tal foi o apoio que durante a Segunda Guerra mundial, apesar das dificuldades desta empresa, foi aprovada a ley $9^{\text {a }}$ de 1942 para o fomento da indústria cinematográfica pelo presidente Alfonso López Pumarejo (Martínez, 1978, p. 84). Este é um precedente importante para as próximas tentativas de criar formas de apoio do Estado à produção de cinema: a lei do sobrepreço, FOCINE e o atual Fondo Mixto para la Promoción Cinematográfica - Proimagenes Colombia criado pela lei de 2003 de cinema.

A produção dos anos 1950 é uma cinematografia de comédias, adaptações de obras literárias, encenação de eventos históricos, crônicas sociais e políticas, e paisagens, que ressaltava a qualidade da produção industrial nacional e do espaço turístico que ofereciam as distintas regiões do país. Recebeu graves críticas: além da falta de qualidade técnica, estes filmes estavam longe do país, das suas crises políticas e problemas que transtornavam o campo e a cidade, o que segundo Martínez afastou o público de cinema e foi o maior desafio que o cinema colombiano enfrentou. As formas de financiamento seguintes teriam efeitos variados e se relacionaram de formas diversas com o público, a questão nacional e a indústria: a lei do sobrepreço de 1972 permitiu que as salas de cinema cobrassem um preço maior no

20 A passagem do cinema mudo para o cinema sonoro é um momento que está muito bem encenado no filme Singing in the rain dos diretores Stanley Donen e Gene Kelly (1952).

21 Jorge Eliécer Gaitán foi um importante líder popular que participou dos debates políticos nacionais em um momento de transformações ligadas ao processo de modernização capitalista. Sua ativa participação política se conjugou ao trabalho no campo da cultura e no campo do direito. Foi reconhecido como um grande jurista e a partir desse lugar liderou mobilizações como a de 8 de junho de 1929 contra a hegemonia conservadora e denunciou graves atos de violência como o massacre dos trabalhadores da United Fruit Company em 1928. Sempre do lado dos trabalhadores, Gaitán ocupou um lugar importante entre os liberais e na esquerda. Nos anos 30 cria o partido UNIR (União Nacional de Esquerda Revolucionária). Em 1936 foi prefeito de Bogotá, saindo antes de terminar o período eleito por causa de desconfortos com as suas transformações. Em 1940 se torna Ministro de Educação onde tentou levar adiante uma reforma à educação sem sucesso. Outras propostas de transformações fomentaram o desgosto entre as elites e classes dirigentes. Sua vida acabou cedo, assassinado no dia 9 de abril de 1948 (ver Marín em, http://www.banrepcultural.org/blaavirtual/biografias/gaitjorg.htm. Acessado em 07/2012). 
ingresso para que o excedente fosse depositado em um fundo destinado à realização. Foram assim realizados muitos curtas-metragens que promoveram a formação de um conhecimento na prática que trariam resultados anos depois.

Entre 1978 e 1993 a Compañía de Fomento Cinematográfico (FOCINE) permitiu aos artistas formados durante os anos anteriores realizarem obras com orçamentos maiores, media-metragens e curtas-metragens, e se deu um importante debate sobre a relação entre apoio, produção, distribuição e exibição (Restrepo, 1980). Os temas do narcotráfico, da marginalidade e da violência começam a ser abordados pelas câmaras, e se abriu um espaço importante ao documentário, que teve sua melhor exposição com a antropóloga Marta Rodríguez e o fotógrafo Jorge Silva (Ministério de Cultura et al, 2007). A atual lei de cinema cria um Fundo misto que permite o aprimoramento da técnica, mas, sobretudo, permite que os jovens que haviam estudado cinema e praticado nos anos anteriores, alguns com mais experiência que outros, possam chegar a produzir filmes, explorar a linguagem e oferecer variadas e renovadas respostas à pergunta sobre como mostrar a Colômbia sua cultura seus problemas e seus futuros (Suárez, 2009).

Depois da Segunda Guerra Mundial, Bogotá contava com 33 salas de cinema, cuja programação era ocupada por filmes estadunidenses, argentinos e mexicanos, assim se estabeleceu a continuidade na projeção de filmes e o aumento do público de cinema ${ }^{22}$, constituindo-se nesse ano como o espetáculo de maior importância e frequência de funcionamento, sendo os filmes estadunidenses os preferidos pelo público bogotano ${ }^{23}$. Nesta época a produção de filmes colombianos era reduzida (uma média de um filme de longametragem por ano) e de baixa qualidade técnica principalmente no que se refere ao som. $\mathrm{E}$ distribuidoras como Cine Colombia, a mais importante até hoje, rejeitaram a exibição de qualquer produção nacional, apresentando somente filmes estrangeiros. O que manteve alguns no ofício foi o cinema de publicidade e particularmente aquele realizado por Marco Tulio Lizarazo, que se dedicou a fazer filmes sobre e para políticos e empresas. Lizarazo introduziu no país o cinema em cores e o uso do procedimento de cinemaScope ${ }^{24}$.

22 No ano de 1944, para uma população de quinhentos mil habitantes na cidade de Bogotá, houve 3.149.058 espectadores e 16.211 apresentações (Martínez, 1978, p. 132).

23 Uma estratégia de exportação, construção de salas de cinema e de dublagem que caracteriza as empresas produtoras de cinema dos Estados Unidos e desenvolvida na maioria dos países que, ao promover suas obras, desencorajam a produção nacional. Mas que têm a vantagem de fazer do cinema uma atividade de importância nas cidades.

24 O primeiro filme a ser realizado com esta lente é The Robe, um filme dirigido por Henry Koster em 1953. Este procedimento permite a ampliação da imagem original que pode ser feita com uma película de $35 \mathrm{~mm}$ ou 
Porém, alguns diretores continuaram realizando filmes, exploraram o país e inseriram novas personagens, outras histórias: o camponês e sua relação com a violência política (Esta fue mi vereda (1959) de Gonzalo Canal Ramírez) e o mineiro e seus problemas no trabalho (El Milagro de la Sal (1958) de Luis Moya). E novas estruturas narrativas e estéticas alinhadas com o surrealismo (La langosta Azul (1954) de Álvaro Cepeda Samudio, Enrique Grau, Luis Vicens e Gabriel García Márquez). No caso, interessa o filme de Canal, já que descreve a chegada e o ataque de um grupo de guerrilheiros a um povoado. No Jornal $E l$ Tiempo aparece a seguinte resenha:

Gonzalo Canal Ramírez fez um filme de 21 minutos, com um impressionante e por vezes cruel testemunho contra a violência, talvez mais denso do que toda a literatura vertida no país sobre um tema tão arraigado na vida nacional. "Esta fue mi vereda" é muito mais do que isso: é um testemunho de grande qualidade cinematográfica e estética. [...] Simplesmente narra com a ajuda de uma câmera e de um excelente grupo de artistas nacionais, como aconteceu a trágica mutação de uma tranquila aldeia na antessala do inferno (Andrade, 1960, Apud Martínez, 1978, p. 201, tradução minha).

A partir dos anos 1960, Martínez identifica uma modernização do cinema, especialmente graças à realização de filmes que aproximavam o espectador das obras e que aproveitam a experiência adquirida pelo trabalho com outras mídias, muitas das quais tinham crescido ao lado da indústria da publicidade. As obras citadas acima constituem a base de um cinema que vai "analisar a realidade" e desenvolver a linguagem fílmica, assim como formará um público mais exigente. Porém, este movimento não dialogou com os demais processos na América Latina de renovação e transformação da prática e da teoria que se manifestaram tanto na realização como na publicação de textos e manifestos (Suárez, 2009, p. 61). Por outro lado, o país vivia uma série de transformações políticas importantes, a aliança entre o partido liberal e o partido conservador chamado "Frente Nacional" impediu outras manifestações políticas de se fazerem presentes e gerou desconforto entre os jovens e grupos de esquerda. A urbanização, a abertura do país a correntes de pensamento estrangeiras, secularização, aumento do acesso à educação, transformação social do papel da mulher. O mundo passava por uma época de efervescência cultural, social, econômica e política que teve repercussões na Colômbia. Durante a década de 1970 no país começam a aparecer as estruturas do narcotráfico, as guerrilhas se transformam para se radicalizar rapidamente e surgem os grupos

de $16 \mathrm{~mm}$. Além disto, o procedimento permite a inclusão da banda de som ótico. 
de autodefesa de extrema direita como uma estratégia de contrainsurgência. Todos estes acontecimentos fazem com que o regime político sofra uma crescente deslegitimação (Gonzáles et al., 2002, p. 44) e outras vozes políticas e atores sociais comecem a aparecer no cenário público. A produção de cinema simplesmente não podia continuar a ignorar as transformações do país nem desligada do seu público.

A crítica de cinema nestes anos se limitava a descrever e elogiar os filmes, sem analisar nenhum dos aspectos propriamente cinematográficos, como a iluminação, os planos, a composição; sem "oferecer elementos para a reflexão e a crítica sobre a função narrativa deste legado de imagens dentro da complexa engrenagem de conceitos como 'o nacional' (o colombiano no caso) e a 'indústria cinematográfica', é impossível ignorar que a constante da violência tem se tornado um elemento penetrante na mesma definição da nação colombiana", como adverte Juana Suárez (2009, p. 11). A observação de Suárez é válida no passado e no presente, por conseguinte é de ressaltar o trabalho de Hernando Valencia Gloekel, o primeiro crítico a estudar sistematicamente o cinema, publicando nas revistas Mito ${ }^{25}$, Cromos e Eco e no jornal El Tiempo. Valencia e um grupo de intelectuais bogotanos fundam a revista Mito, que segundo o escritor, jornalista, poeta e crítico Juan Gustavo Cobo Borda (Cobo, 2009) é fundamental no estabelecimento da crítica de cinema, porque esta era feita por pessoas que estudavam cinema em cidades como Paris e Roma, cuja visão cosmopolita levou-os a traduzir textos de Brecht e Fellini, escrever sobre o cinema contemporâneo e a se perguntar pela especificidade da linguagem do cinema (signos e convenções, estrutura de significados, arte criativa e não da reprodução, ator como elemento funcional dentro da obra) pela relação entre cinema e história, o desenvolvimento do gênero, a relação entre imagem e som, e pela adaptação cinematográfica da literatura e do teatro.

Ou seja, o mundo do cinema começava a definir os termos e as categorias para pensar a produção nacional, suas particularidades e sua dimensão política, assim como a estabelecer vínculos com outros campos do conhecimento; uma atividade que agora passava a ser atendida pelos intelectuais e que propunha criar vínculos, além do divertimento, com a sociedade. Isto em uma época de graves censuras promovidas pelo presidente conservador

25 “A revista Mito fundada por Jorge Gaitán Durán e Hernando Valencia Goelkel [...] foi sem dúvida a publicação cultural mais importante do século XX. É conhecida sua posição de esquerda, de verdadeira liberdade, mesmo que alguns dos colaboradores estivessem afiliados ao partido conservador [...]. A principal característica de Mito é haver estado em contato com o mais novo do seu tempo, e refleti-lo na Colômbia [...]'(Cobo, 2009). 
Laureano Gómez, que deu início a uma série de políticas que desfaziam o que foi feito pelo presidente anterior, Pumarejo, em matéria de apoio à produção de cinema.

Outros críticos, como o reconhecido escritor Gabriel García Márquez, os diretores de cinema Álvaro González Moreno, Guillermo Angulo e Francisco Norden, aportariam formas de pensar a relação entre cinema, arte e sociedade. Pontos de vista que servem de referência para pensar o cinema colombiano feito nessa década. Em 1949, Luis Vincens, Hernando Tellez, Bernardo Romero Lozano, Gloria Valencia de Castaño, Carlos Martínez e Jorge Valdivieso criaram um importante cineclube: o Cine Club de Colombia, que se propôs o objetivo de "melhorar o gosto público, chamar a atenção sobre as obras perduráveis da cinematografia e impedir que certos filmes fossem esquecidos. [...] é nessa função de relembrar o velho que pode ser valorado com exatidão o novo" (Martínez, 1978, p. 221). O que indica a aproximação e participação do público no cinema, pela visualização e discussão de obras fílmicas. Tal é o sucesso desta empresa que em 1966 o grupo abre as portas da Cinemateca Colombiana, e em 1972 é criada por decreto a Cinemateca Distrital ${ }^{26}$, ambas com sede em Bogotá.

O cine club de Colombia é o principal, mas não o único cineclube que exibiu e discutiu cinema no país (cineclube e cinemateca La Tertulia, cine club de Cali, Nueva Generación, de la casa de la amistad de los pueblos, de la Universidad del Valle em Cali, cine club de Medellín, cinemateca El Subterráneo, mundo universitário, em Medellín, cine foro estudiantil, de la universidad Jorge Tadeo Lozano, cine club de Bogotá, la Linterna Mágica, de la Universidad Central, de la Universidad Pedagógica, em Bogotá, de la Universidad de Cartagena, em Cartagena, para ressaltar alguns) estes e a Cinemateca cumprem uma função importante na formação de públicos e na gestação de perguntas e desafios à produção nacional. Desde então proliferam cineclubes nas cidades colombianas, alguns dos quais permanecem funcionando até hoje e que estudam não só os grandes nomes da cinematografia mundial como também os fenômenos comerciais e as produções nacionais. Além disto, e graças à tecnologia digital, muitos destes cineclubes se dedicam ao ensino e produção de curtas-metragens junto a jovens, crianças, comunidades das periferias e estudantes de cinema. Também estes lugares são importantes na distribuição e exibição de obras que muitas vezes não chegam às salas de cinema comercial e que se perdem nas redes da indústria. Ressalto este movimento de cineclubes, pois algumas das perguntas e orientações teóricas assim como

26 Website da cinemateca distrital de Bogotá é www.cinemateca.com.co 
a metodologia desta dissertação nasceram durante a minha participação na Corporación Cultural El Barco, criada no ano de 2004, na Biblioteca Pública Virgilo Barco de Bogotá como cineclube, vigente até hoje. Se as linhas escritas sobre cinema, assim como a própria produção estão em concordância com os momentos sociais, políticos e culturais das sociedades, não podemos deixar de pensar na ação dos cineclubes para refletir sobre o cinema colombiano e, como pretendo, nas seguintes páginas, discutir a relação destas imagens e as narrações da violência do conflito armado colombiano.

A "construção de um discurso fílmico sobre a violência" é um dos assuntos que Suárez (2009) aborda para pensar se o "cinema colombiano tem contribuído com alguma coisa diferente ao corpus de discussão sobre La Violencia ${ }^{27}$ " (ibid., 59). A partir de uma comparação entre os cenários rurais e urbanos, a pesquisadora chega à pergunta de porquê "La Violencia e as outras violências são o discurso mais amplo, mas não o mais político" (Loc. cit). Para a pesquisadora, o cinema não teria sido político porque os filmes "não conseguem conformar uma narrativa nacional cinematográfica e, salvo algumas exceções, não conseguem oferecer um conjunto cinematográfico que desafie o status quo" (ibid., p. 87). As obras são avaliadas como não sendo politizadas na posição ideológica e simplesmente ilustrativas. É com o filme Rodirigo D no futuro (Victor Gaviria, 1990) que se marca uma ruptura com a época anterior e se começa uma época de novas expressões fílmicas, esta mais na linha da "denúncia social" propriamente dita.

Começa, pois, um interesse pelas margens: desplazados ${ }^{28}$, exclusão e pobreza se tornam temas recorrentes dos filmes dos anos 1970 e 1980. Embora em 1915 a criminalidade tenha sido objeto de um filme, El drama del 15 de octubre, realizado por Vicenzo Di Domenico, e a população marginal tema de outro filme de 1925, Bajo el cielo antioqueño de Arturo Acevedo Vallarino, estes não são temas que preocupam os cinegrafistas deste momento. Teria que chegar o ano de 1968 para que Marta Rodríguez e Jorge Silva mostrassem à sociedade colombiana este mundo em vários documentários. O mais importante deles, Chircales (1968), conta a história da vida de uma família que trabalha na produção de tijolos em uma fábrica localizada na periferia de Bogotá. Anos depois, são as crianças de rua nas grandes cidades as

27 A expressão La Violencia é utilizada para nomear o confronto entre os dois partidos políticos tradicionais: Liberal e Conservador durante os anos 1950 (c.f. Guzmán et al., 1968). Esta década marcou a história colombiana e permanece como referência fundamental para pensar a violência contemporânea no país.

$28 \mathrm{O}$ tema dos desplazados será desenvolvido com mais detalhe no primeiro capítulo desta dissertação. Referese às pessoas que são obrigadas a abandonar seu lugar de residência como resultado do conflito armado (Granada, 2008). 
personagens que interessam aos documentaristas e com isto surge uma das melhores críticas à representação da pobreza, pois a vontade de mostrar e denunciar é vista por Carlos Mayolo e Luis Ospina como uma vontade quase pornográfica de mostrar o sofrimento do outro; estes dois diretores inventaram o termo de pornomiseria para qualificar este tipo de estética.

Finalmente, como já disse, é Victor Gaviria quem afina discurso e linguagem fílmica, produzindo um documentário de ficção que mostra a vida na periferia de Medellín a partir da própria visão, desejos e histórias dos moradores desta região: vidas atravessadas (e organizadas) pelas dinâmicas do narcotráfico, pelas formas por meio das quais este negócio ditou o modo das relações familiares e sociais, criou cultura, linguagem e estabeleceu um lugar específico para os indivíduos relacionados com a compra e venda de drogas se posicionarem diante do país. Gaviria mostra um "enfoque estético de como olhar, escutar, narrar e representar a urbe" (ibid., p. 99) que, segundo Suárez, "é um cinema que aproxima demais da realidade e nos impede de evadi-la, [um] excesso de realidade [que] não se dá sem gerar certo desconforto no espectador, muitas vezes traduzido em rejeição" (ibid., p. 100, tradução minha). Tal desconforto pode ser experimentado como uma crítica à representação da violência pensada a partir da experiência do diretor com os atores e suas histórias ${ }^{29}$.

A crítica que Mayolo e Ospina fazem ao cinema de denúncia funciona no sentido de inspirar um tipo de cinema que, ao invés de simplesmente mostrar a dor alheia e pretender com isto uma certa sensibilização do público para com as formas de vida marginais, inventa linguagens que dialoguem com as personagens, que permitam a sua participação na construção das imagens e que apresentem filmes que não se limitem a mostrar/exibir o outro, mas que elaborem olhares e desloquem discursos. La sombra del caminante é um filme que participa desta discussão, pois se interessa precisamente pelas pessoas que, embora habitem o centro da cidade, são marginais, não só porque são pobres ou porque vêm de lugares longínquos, mas porque sua condição de vida é resultado dos processos de exclusão e de violência. Por isto, Guerra se propõe a quebrar o limite da narrativa que mostra e explica para elaborar um filme que vai além e pensa na experiência, no silêncio, nos fragmentos de vida

29 Uma das características mais importantes do cinema de Gaviria é o trabalho com não-atores; pessoas com as quais ele convive e a partir da qual escreve o roteiro e elabora toda a proposta estética do filme. Este procedimento é tanto uma posição artística quando política, pois coloca a questão de mostrar na tela o rosto cotidiano das pessoas. Uma sorte de desvio dos rostos clássicos do cinema de Hollywood que povoa nossas telas. Também é uma forma de colocar a questão da representação da realidade, pois estas pessoas ao se representarem a si mesmas, estão também construindo uma persona, uma personagem. Ver Pessuto (2011) para uma discussão detalhada sobre a questão do "não" ator, como propõe a pesquisadora, no cinema iraniano. 
que estas pessoas conservam e organizam para recompor uma biografia que deve lidar permanentemente com o passado e o sofrimento.

O enfoque da narrativa será, então, o da possibilidade ou impossibilidade de um diálogo, da reconciliação e do reconhecimento. O formato em branco e preto, o percurso pela cidade, o tempo pausado da narrativa e a reflexão profunda sobre a nação em crise [...] La sombra mostra outra dimensão da tragédia, reunindo frentes e histórias distintas [...] continua sendo um filme sobre a violência na Colômbia, mas esquiva os lugares comuns. A partir dos primeiros minutos adverte-se que se trata de um filme com outro enfoque estético e com uma reflexão teórica, até certo ponto ausente na vertigem da produção comercial sobre o tema (Suárez, 2009, p. 192, tradução minha).

Suárez examina as periodizações estabelecidas para o cinema colombiano, dentre as quais duas em especial são de interesse: ambas partem dos períodos dos historiadores da violência para identificar os diferentes momentos da produção fílmica. Assim, às categorias de "primeira violência", "segunda violência" e terceira violência" se sobrepõem as de "primeiro cinema", "segundo cinema" e "terceiro cinema" (Pulecio, 1999 e Kantaris, 2008), de modo que imagens e acontecimentos estariam relacionados no tempo (imagens como um tipo de resposta aos acontecimentos) e no entendimento (chaves de análise dos eventos sendo utilizados para criar e avaliar as imagens). Para Kantaris (2008), a periodização é útil para entender a multiplicidade de violências e seus entrelaçamentos, mas não para entender o que Martín-Barbero chamou do "espessor cultural destas violências, tanto da sua origem como da sua trama" (apud. Kantaris, 2008, p. 111). De modo que o exame de filmes traria à discussão "algumas das estratégias que são adotadas para representar os efeitos da violência [...] mas também, e muitas vezes de forma radical, a imbricação da violência com os sistemas de representação" (Loc, cit.).

A relação parece simples: existe nação na medida em que é definida uma identidade nacional. Porém, é precisamente a maneira como se define essa identidade o que deve ser posto em evidência. Não é suficiente afirmar que a identidade nacional é uma construção como também deve ser apontada sua utilidade, assim como os procedimentos através dos quais esta ficção se faz necessária (Arias, 2008, p. 148, tradução minha).

O cinema participa desta construção do nacional e da identidade coletiva se 
relacionando com os processos de monumentalização, recuperação de memória e memórias, escritura da história e as manifestações que desafiam e transformam as definições hegemônicas sobre o que seriam esses conceitos. Na Colômbia, a relação entre apoio do estado e marginalidade, assim como a produção descontínua de filmes e a obrigação dos diretores de procurarem meios alternativos para finalizar suas produções, fazem com que este seja um lugar onde se perguntar pelos fragmentos, os ruídos e as dissonâncias dos processos de construção nacional e dos discursos sobre a violência e suas consequências. É também o lugar onde se deve procurar maneiras distintas de mostrar e expressar a violência, como Cortés (2009) indica na sua análise sobre arte, pois seria uma forma que transforma temporalidades, constrói lugares e abre espaços para falar, inserir problemas, criar personagens, e deslocar o discurso oficial, normativo e acadêmico sobre a violência em todas suas dimensões.

Poderemos estar assistindo, como se pergunta Juana Suárez, a uma "mudança no enquadramento" das formas de representação da violência? Filmes como La primera noche (Luis Alberto Restrepo, 2003), El colombian dream (Felipe Aljure, 2006), Perro come perro (Carlos Moreno, 2008), La sombra del caminante (Ciro Guerra, 2004) e PVC-1 (Spiros Sthatoulopoulos, 2007) emocionam o público e o levam a dar uma reposta afirmativa. A própria existência da Lei de Cinema de 2003 e a criação do Fondo Mixto de Promoción Cinematográfica - Proimagenes Colombia, o aumento da produção nacional (no ano de 2011 foram produzidos 18 filmes com apoio do fundo) ${ }^{30}$, a participação dos filmes colombianos em festivais internacionais, o interesse que estes têm despertado em críticos estrangeiros ${ }^{31}$ e uma crescente atenção de críticos e estudantes colombianos, desenham um panorama otimista. Mas ainda não será respondida a pergunta formulada por Suárez, pelo menos não definitivamente; e por isto o melhor é pensar nas formas que existem de mostrar a violência, observar em detalhe as propostas, pensar sobre as relações entre cinema e sociedade e os processos

30 Segundo estatísticas publicadas no site Proimágenes, a produção com apoio do Fundo tem aumentado: no ano de 2000 foram lançados 4 filmes; em 2001, 7 filmes; em 2002, 4 filmes; em 2003, 5 filmes; em 2004, 4 filmes; em 2005, 8 filmes; em 2006, 8 filmes; em 2007, 12 filmes; em 2008, 13 filmes; em 2009, 12 filmes; em 2010, 10 filmes e em 2011, 18 filmes. Disponível em: http://www.proimagenescolombia.com/secciones/cine_colombiano/estadisticas/cine colombiano.php.

Acessado em 07/2012. Não conto os filmes produzidos de forma independente que circulam em festivais locais ou pelas salas de cineclubes. Embora os dois filmes que me interessam tenham sido produzidos à margem da lei, sem recursos do Estado, são dois filmes que pelo seu sucesso internacional têm um impacto importante na lei e na discussão sobre a mesma, mais do que talvez o teriam para pensar a produção independente.

31 Já tive a oportunidade de conhecer pesquisadoras brasileiras que se interessam pelo cinema colombiano e levam em consideração La sombra del caminante. (para um exemplo, ver Fusco, 2012). 
culturais e políticos dos quais o cinema participa. Desta forma poderemos visualizar esta renovação e, também continuar o processo de construir novas imagens que lidem com o desejo de contar nossas histórias, de desarticular os discursos oficiais, de nos vermos renovados na tela e nos pensarmos criativamente através das imagens em movimento. 
Capítulo 1

Sombra do passado, sombra do presente 
"Pour savoir il faut imaginer [...] N'invoquons pas l'inimaginable. Ne nous protégeons pas em disant qu'imaginer cela, de toutes les façons - car c'est vrai -, nous ne le pouvons, nous ne le pourrons pas jusqu'au bout. Mas nous le devons, ce très lourd imaginable. Comme une réponse à offrir, une dette contractée envers les paroles et les images que certains déportés ont arrachés pour nous au réel effroyable de leur expérience. Donc, n'invoquons pas l'inimaginable. [...] Ces lambeaux nous sont plus précieux et moins apaisants que toutes les oeuvres d'art possibles, arrachés qu'ils furent à un monde qui les voulait impossibles. [...] Images malgré tout: malgré notre propre incapacité à savoir les regarder comme elles le méritaient, malgré notre propre monde repu, presque étouffé, de marchandise imaginaire" (Didi-Huberman, 2003, p. 11)

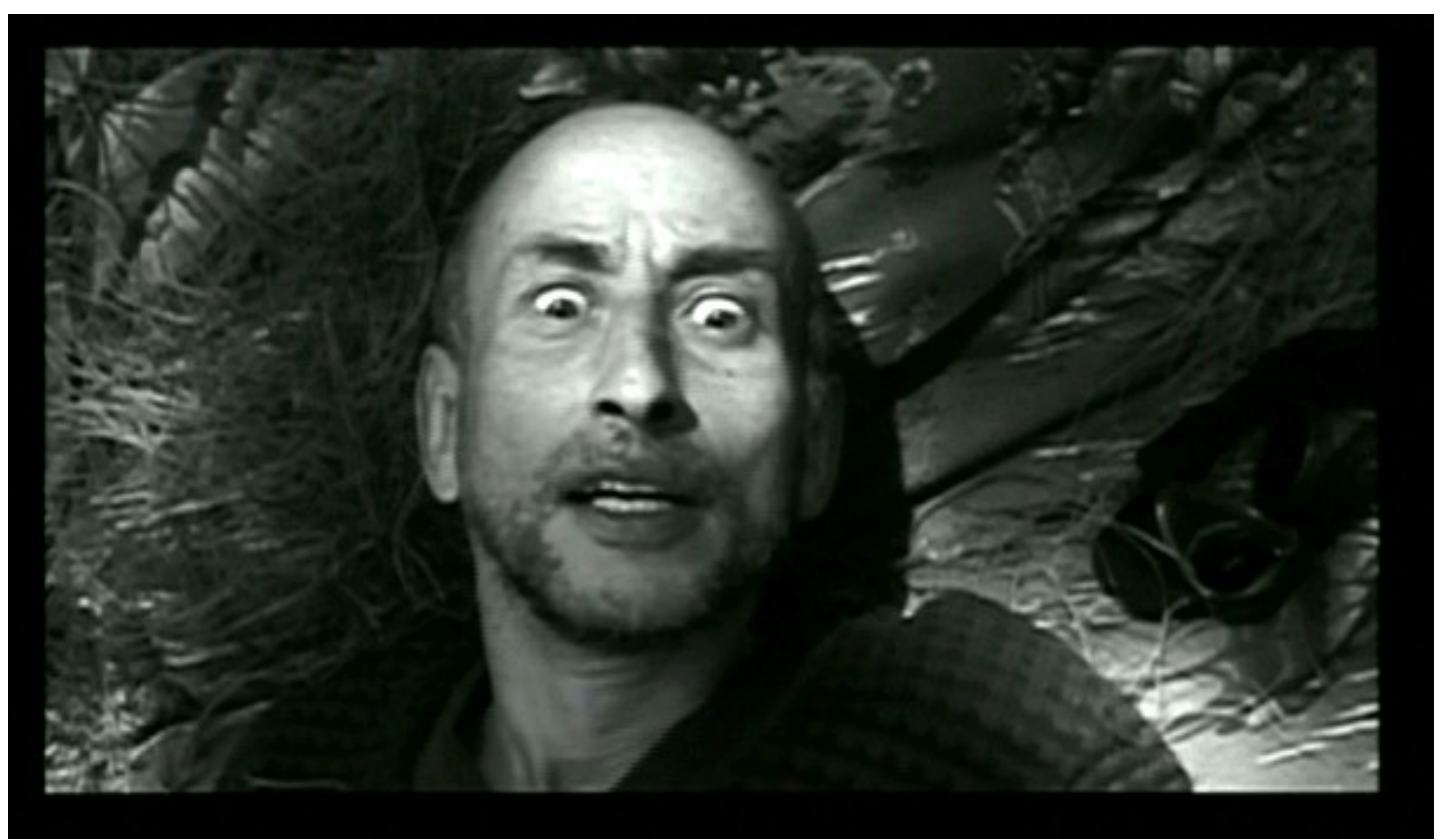

Frame. La Sombra del caminante. (Ciro Guerra, 2004) 

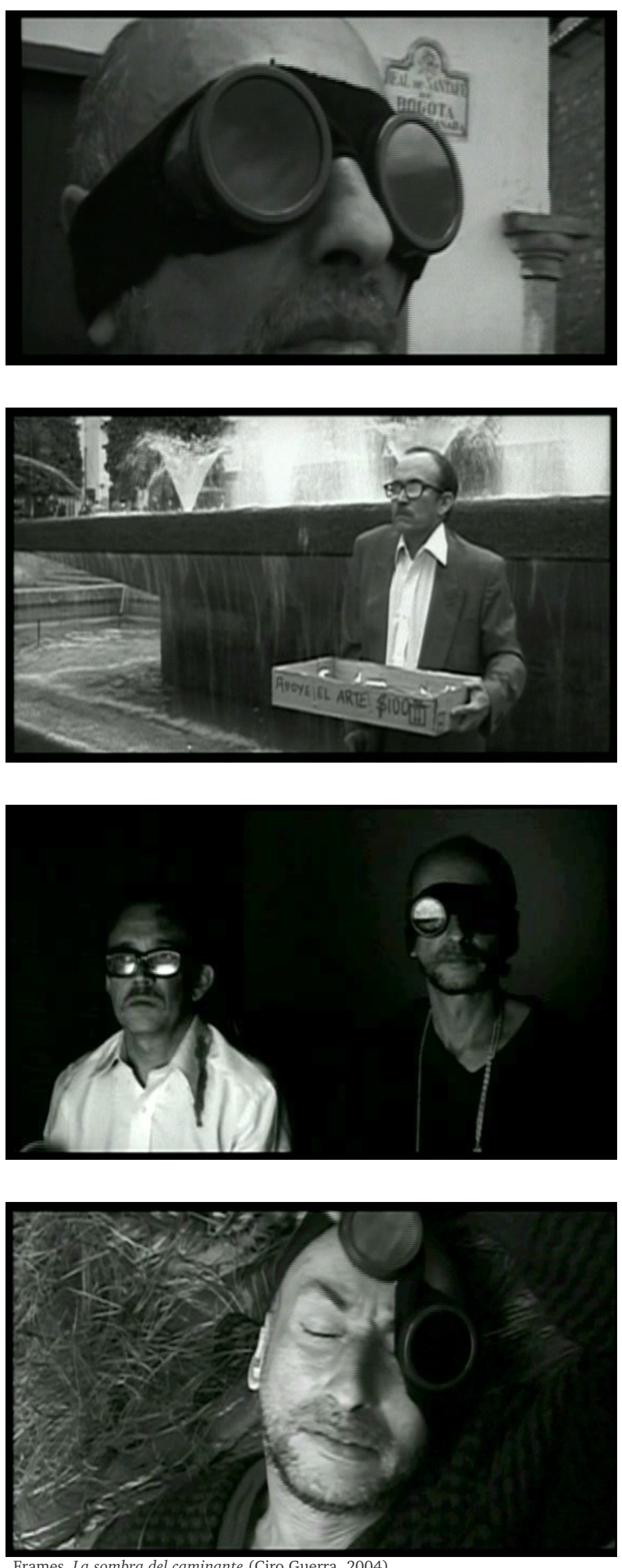
Mañe (César Badillo) é um deficiente físico, não tem a perna direita, ele mora em um quarto de aluguel na casa de Doña Marelvis (Inés Prieto Saravia) e do irmão dela, o Sargento Osvaldo Jaimes (Lowin Allende) e enfrenta sérios problemas de dinheiro. Mañe é um sujeito desiludido que todo dia é atacado por alguns jovens (Julián Díaz, Andrés Gaitán e Diego Manzano), cruel evento, que leva um homem (Ignacio Prieto) a ajudá-lo. Este, para ganhar algumas moedas no dia a dia, carrega pessoas em uma cadeira que leva nas costas, um "silletero". Ele mora em uma barraca construída com plástico nas colinas da cidade de Bogotá, cobre seus olhos com um óculos como os de aviador, protege-se do sol com uma sombrinha preta e reiteradamente bebe um chá que prepara com as folhas de uma planta que carrega. Os dois homens são as personagens principais de uma história de ajuda e silêncio, de um encontro que acordará um violento passado do qual ambos fogem. O centro de Bogotá os recebe e os reúne com outras pessoas que chegam na cidade procurando meios de subsistência. Dívidas, desemprego, trabalho informal, controle policial e solidão, são assuntos que atravessam esta relação e constroem a história do filme La sombra del caminante.

A pergunta pelo tipo de experiência que o filme oferece será abordada a partir de três eixos de descrição ${ }^{32}$ : em primeiro lugar, as diferentes estratégias por meio das quais o filme interpela o espectador; em segundo lugar, o olhar como vetor, forma de vincular e desvincular personagens, ações e situações, e de colocar o espectador em um lugar difícil a partir do qual observar o filme; e em terceiro lugar, a construção de duas personagens improváveis e plausíveis que constroem uma intimidade muda, o que lhes permite ter simultaneamente, atitudes solidárias e estranhas - como a de ajuda sem motivo - e agressivas - a não resposta às perguntas feitas -, e revelar fragmentos de verdades, passados, culpas. Uma relação de solidariedade que surge da oposição entre as partes. Por meio desta descrição do filme, pretendo me posicionar diante das imagens de La sombra del caminante e tentar apreciar o

32 Estes eixos de descrição surgiram da visualização do filme e de sua posterior textualização. Utilizo essa estratégia para me aproximar deste objeto de pesquisa que é o filme e me localizar na posição de espectadorapesquisadora, sem recorrer a explicações sobre a recepção do filme. Esta é uma posição que Hikiji (1998) afirma na sua dissertação de mestrado: o antropólogo- espectador "vê no cinema não meio, mas objeto da pesquisa. Diante da imagem, dedica-se à decifração. Identifico-me com este, que toma o cinema como “campo", passível de observação e interpretação antropológica” (ibid., p. 9). 
grau de contribuição que a obra traz para a discussão do problema da construção fílmica da violência no interior do pensamento antropológico, que se relaciona com a narração da experiência; pretendo, ainda, construir vínculos entre a análise fílmica e a reflexão sobre formas de narrar a realidade, especialmente quando esta está relacionada a situações de violência. Tal linha de pensamento se interessa não pelo cinema como representação - ao avaliar a aproximação ou distanciamento do real das imagens -, mas pelas estratégias que o filme utiliza para configurar uma experiência e, quiçá, propor olhares divergentes. Antes, vale a pena dizer que esta não é a única forma de entender o filme,

A questão é que o cinema consegue, em ocasiões, mais do que nos representar o real, fazer uma realidade particular, não pelo simples fato de mostrar uma invenção totalmente subjetiva, mas porque consegue dar voz a uma parte do real que inclusive ainda não considerávamos como real. Assim como mostra Rancière, não é necessário que o cinema deixe de contar histórias para ser político [como o afirmavam as vanguardas russas]; no entanto, sua dimensão política também não se encontra simplesmente nas histórias que conta, mas provavelmente na realidade que revela - constrói - nestas ficções narrativas (Arias, 2010, p.143, tradução minha).

Juan Carlos Arias, autor da citação acima, realizador de cinema e pesquisador de arte, questiona neste livro a relação entre crítica, teoria e prática de cinema e reflete especificamente sobre a relação entre cinema e política. $\mathrm{O}$ autor discute se o político no cinema se relaciona com o tipo de conteúdos que este pode mostrar (representação), ou se se refere à capacidade de mostrar, própria da imagem ${ }^{33}$. Posicionando-se à favor da última opção, afirma que haveria uma definição de cinema além da representação e da política, além da organização do Estado, como a "possibilidade de configuração de formas de vida" (ibid., p.31), de experiência. Neste sentido, o cinema se relaciona com o alargamento das possibilidades de vida, com mostrar o que não é mostrável; nesse sentido, "que a imagem se oponha ao inimaginável não quer dizer que o torne imaginável, quer dizer que mostra o acontecimento enquanto inimaginável" (ibid., p.37 cursiva no original).

O filme constrói, a partir de uma variedade de estratégias, diversas maneiras de interpelar o espectador. Isto se relaciona com a modelagem de uma série de associações que são oferecidas ao espectador pela variação de planos e o fluxo de imagens (Aumont, 1983).

33 Didi-Huberman (2003) afirma que a imagem é uma forma de resistência porque tem um tipo de conteúdo visível que nos aproxima de uma realidade desconhecida. Mostrar o desconhecido, mas sobretudo mostrar o impossível não como possibilidade, mas enquanto impossível. 
No início do filme, na apresentação das personagens, seus espaços e objetos, os planos abertos são utilizados para enquadrar o homem da cadeira e os fechados são reservados para Mañe. Haveria aqui uma vontade de criar empatia por Mañe - e não pelo homem da cadeira -, pois seu mundo e gestos são mostrados de perto, durante um tempo maior. Em outro momento, nas cenas em que o homem da cadeira carrega Mañe pelas ruas do centro de Bogotá, são enquadrados os olhares que pedestres dirigem às personagens, as atitudes de estranhamento indicam a esquisitice da aparência de cada um e a particularidade do conjunto, da maneira deles se deslocarem pela cidade. Afinal, alguém carregando uma pessoa que vai sentada em uma cadeira levada nas costas pelas ruas da cidade, é raro e se torna uma imagem violenta, como afirmou o diretor do filme ${ }^{34}$. A empatia, que antes havia sido privilégio de Mañe, tornase difícil, pois tudo indica que ele é diferente, estranho. Da mesma forma, a cidade aparece como um lugar desconhecido, o preto e branco (p\&b) cria um distanciamento. As imagens cotidianas da cidade, em planos de detalhe, mostram pessoas, coisas, pequenos espaços que passam despercebidos quando caminhamos pelas ruas; as vozes e gritos cotidianos que já havíamos esquecido são escutadas em relevo. A configuração do espaço não cria uma mimesis da cidade real; a cidade do longa não respeita a organização urbana: nomes são irrelevantes, ruas aparecem em desordem, lugares separados por vários quarteirões, de repente, estão próximos. O sentimento de estranheza impera ao longo do filme. As relações com as personagens e a formação do espaço configuram como que um obstáculo ao observador, estes elementos não abrem uma janela de percepção, contudo, o problema não é de verossimilhança.

Retomando a ideia do diretor, de que carregar uma pessoa em uma cadeira levada nas costas é uma imagem violenta, as personagens do filme não poderiam ser classificadas como tipos ou inclusive estereótipos dos "desplazados", pois, tudo indica que estamos no registro da alegoria. Ciro afirma que o filme queria tratar do que estava acontecendo nos anos de 2000, 2001 na Colômbia, particularmente da chegada massiva de desplazados em Bogotá e a ida destas pessoas à rua para trabalhar vendendo objetos, desenhando, cantando, fazendo malabares, etc., a partir de um enfoque que se distanciasse do formato da comédia e da notícia. Deste modo, o diretor traz uma personagem de um lugar rural, afastado - cuja atividade foi típica da colônia e que hoje sobrevive em pouquíssimos lugares do país - ao contexto urbano e para atuar no meio desse mundo do trabalho informal. Com este

34 Entrevista com Ciro Guerra, realizada em janeiro de 2011 na cidade de Bogotá pela pesquisadora. 
personagem, Ciro expressa a dificuldade de inserção das pessoas na cidade, o seu status liminar, pois saem do seu lugar de moradia para ir a um lugar que não os recebe e que carece de espaços e estratégias para inserir estas pessoas nas dinâmicas da cidade. Nesse processo, de morar na cidade e constantemente esbarrar com dificuldades, essas pessoas abrem brechas, espaços, trajetos até inventam atividades para habitar o novo lugar. Ademais, o diretor comenta sobre a violência e sua ambiguidade, uma vez que na situação do "homem que carrega homens", como diz Guerra, não é claro quem tem o poder, se quem carrega ou se quem é carregado, mas sempre é uma relação de dominação porque só um deles poderá decidir qual é o trajeto, o ritmo, as paradas e os desvios, o outro deverá calar e obedecer.

Devagar distingue-se a forma de um caixão que está em pé, sustentado pela parede branca do quarto, é feito de madeira e não ostenta o trabalho cuidadoso do carpinteiro, é um ataúde qualquer destinado a guardar a morte de qualquer um. Um homem magro, vestido com roupas escuras, indiferente, pega com as mãos o ataúde, coloca-o sobre uma mesa do quarto e o transforma habilidosamente em uma cadeira estranha: sem os dois pés dianteiros, com os dois pés traseiros curtos formam um ângulo de 90 graus com o assento da cadeira. A parte de baixo das costas está coberta com espuma, amarrada com uma corda de sisal branca e na parte de cima dois cintos velhos, envolvidos com espuma atada no mesmo estilo daquela das costas, estão atados para servir de alça. Os movimentos deste homem são mecânicos, é um carpinteiro que já repetiu tais movimentos e golpes de martelo muitas vezes na vida.

A sequência de apresentação dos créditos é construída por uma série de planos curtos e fechados, que vão se abrindo até a apresentação do título do filme. A primeira cena é construída de primeiros planos das mãos trabalhando, cortando a madeira com um serrote, polindo com lixa os pedaços de madeira ou batendo o martelo sobre uma pontilha; os planos são rápidos e acompanham, passo a passo, o trabalho do homem até que, no final, a câmera recua e enquadra a cadeira. O detalhe no enquadramento da construção do objeto e sua aparição no início do filme indica sua centralidade. Os nomes da equipe de produção aparecem sutilmente em letras brancas e pequenas nas esquinas do quadro, não interferindo na imagem do homem. O único som é o da madeira sendo cortada, lixada e martelada. 
Apresentam-se os elementos de tom e ritmo que serão desenvolvidos ao longo do filme: preto e branco, elaboração de cenas de trabalho manual em planos rápidos e fechados, cenas da cidade e suas ruas em planos amplos e demorados, os habitantes e sua relação com os protagonistas do filme. O som está presente em certos momentos e direciona o olhar sobre detalhes da vida na cidade e da moradia das personagens. Estes elementos oferecem uma chave de leitura do filme que, neste momento inicial, serve para localizá-lo em um espaço cinematográfico que ultrapassa o próprio filme e o cinema produzido na Colômbia, possibilitando o estabelecimento de relações e comparações úteis para pensá-lo.

O neorrealismo italiano, o filme Los olvidados de Luis Buñuel e os cineastas colombianos Victor Gaviria e a dupla composta por Luis Ospina e Carlos Mayolo compõem o campo no qual pretendo situar a obra em questão. No neorrealismo italiano ${ }^{35}$ temos um tipo de câmera que permanece sempre próxima às personagens, não necessariamente pelo uso de planos fechados e sim pela duração dos planos nas personagens, falas fragmentadas e silêncios cabem no filme. Isto se dá graças a um interesse sobre as experiências difíceis da vida, as situações que nem sempre podem ser contadas de forma linear, lógica, pois estão atravessadas por dores, memórias e, desejos; em suma, por elementos desestabilizadores da narrativa biográfica conexa e coesa, explicativa do presente.

O surrealismo do diretor espanhol Luis Buñuel, construído no filme Los Olvidados (1950), é ponto de referência e comparação pela inserção de elementos, objetos e situações estranhas em contextos familiares e, ao contrário, elementos cotidianos em contextos estranhos: como os óculos de aviador cobrindo os olhos do homem da cadeira, ou uma planta qualquer na posição de objeto de amizade. O longa-metragem de Buñuel também é relevante pela maneira de deslocar a imagem da miséria pela encenação das formas de imaginação das crianças de rua. É uma visão cujo enquadramento privilegia as alucinações e as narrações, não as estatísticas e as histórias oficiais. No filme de Guerra não temos uma análise da violência, do deslocamento forçado ou das condições de vida em Bogotá; este quadro explicativo é deixado de lado para enquadrar flashbacks misteriosos que narram a ausência de sentido dos

35 Em Vanoye e Goliot-Leté ([1992]1994) estão enumeradas outras características: com origem na Europa de pós-guerra, em uma época de ausência de recursos financeiros, de crise política e ideológica, trata-se de ser testemunho desse mundo e vincula-se ao documentário (ibid., p. 34). O neorrealismo italiano é um dos que dá lugar ao cinema moderno: apresenta narrativa frouxa, menos dramática, com momentos de vazio e lacunas; os personagens são desenhados com menos nitidez, em crise; as fronteiras entre o subjetivo e o objetivo, os distintos formatos e a temporalidade são ambíguas; há forte presença do autor e propensão à reflexividade. (ibid., p.35-36) 
eventos do passado, as perguntas sem resposta, a dúvida da presença, a certeza das marcas da violência no corpo.

Em relação às últimas duas referências citadas; o colombiano Victor Gaviria, no filme Rodrigo D no futuro (1990) apresenta um filme de ficção que narra as histórias de vida de um grupo de jovens moradores do bairro el Diamante localizado na comuna Noroccidental ${ }^{36}$ de Medellín (Antioquia). O diretor faz um trabalho criativo com não atores, moradores do bairro, para criar o argumento do filme e as personagens; as pessoas encenam suas histórias e mostram os lugares que lhes são familiares, as casas, bares, espaços de lazer. De modo que um espaço que é reiteradamente nomeado, representado e delimitado pelos grandes veículos de comunicação, é mostrado através dos caminhos desconhecidos e contando histórias que não tinham sido contadas ${ }^{37}$. Novamente, vemos o interesse de mostrar o marginal sem mostrálo de formas óbvias, estereotipadas, para construir uma presença a partir da subjetividade daquele que é categoria jurídica, social ou econômica. "Enfim, algo que, a seu modo, o documentário tem estado a buscar apoiado na performance diante da câmera assumida como ação na esfera do contingente, do que ocorre e pode desafiar uma rede de noções e saberes" como diz Xavier (2003, p.55), a respeito do cinema de Eduardo Coutinho.

Já a dupla Ospina-Mayolo é responsável pela crítica à imagem da miséria produzida por documentários e pela mídia ${ }^{38}$. Assim, será especial para esta análise o filme Agarrando pueblo (1978). Trata-se de um (falso) documentário que aborda a realização de um documentário sobre as crianças de rua, mostrando o caráter vampiresco dos diretores que exploram as realidades dolorosas para (comercializar) sensibilizar um público (bilheteria). Imagens que alimentam as redes do mercado e esvaziam toda possibilidade de pensar o problema. Mañe e o homem da cadeira pertencem ao mesmo universo, o da marginalidade, e Guerra apresenta uma tentativa não só de humanizar estas vidas (dar-lhes corpo e essência),

36 Comuna é o nome dado aos bairros da periferia da cidade de Medellín. São bairros onde a violência criminal é amplamente praticada, assim como o comércio de drogas, armas e a prostituição. As pessoas que ali moram são marginalizadas em função das imagens de violência, discursos, estereótipos, etc., utilizadas para falar sobre este espaço.

37 Um excelente exemplo do trabalho com não atores no trabalho criativo é o filme Cidade de Deus (2002) dirigido por Fernando Meirelles. Apesar de todas as críticas ao filme sobre estetização da violência, eu resgato a produção e o trabalho com os jovens porque foi a partir da preparação dos não atores e das discussões em grupo que o roteiro foi se modificando, tanto assim que ele foi reescrito várias vezes para se ajustar ao que estava acontecendo nos momentos preliminares da produção.

38 Luis Ospina define esta produção de imagens da pobreza e da marginalidade nas grandes cidades colombianas de pornomiséria, pois o que caracteriza tais imagens é o grotesco, tem-se o mostrar por mostrar e, diria eu, a partir do olho clínico e patologizador. 
como de mostrá-las complexas, resultados não apenas da exclusão econômica. Em geral, podemos pensar que se tratam também de propostas estéticas para contar histórias locais, uma prática de pensar a sociedade através do cinema e apresentar figuras, imagens e situações contraditórias, opostas e até constrangedoras, com o objetivo de despertar, ver as mesmas coisas de modo diferente para instigar o pensamento.

O homem coloca a cadeira nas costas com as alças como se fosse uma mochila, vira à esquerda e pega os óculos que estão sobre a mesa. Aqueles semelhantes aos de um aviador que impede as pessoas de verem seus olhos. O óculos está construído com duas lentes pretas e redondas fixadas em uma base redonda e também preta, como dois pequenos tubos, ambos incrustados em uma faixa de tela preta que cobre suas orelhas. O rosto do homem da cadeira permanece um mistério. Apenas no momento em que ele pega os óculos, a câmera enquadra por um instante seu rosto que aparece desfocado, refletido nos óculos.

No cinema clássico de ficção ${ }^{39}$, o enquadramento do rosto humano cria a ideia de "espelho da alma", o espelho da ação que se realiza no campo ${ }^{40}$, o meio que expressa a fábrica, as revoluções, a guerra: o rosto é paisagem (Morin, 1956, p.61). Este rosto assim enquadrado e o uso de certa música e iluminação propicia a identificação do espectador com a imagem da tela, o que dá início ao processo de participação no filme descrito como o processo que completa e "dá vida” às imagens (ibid., p.78). Béla Balázs (apud. Xavier [1983] 2003) crítico húngaro de cinema, afirmou, em $1923^{41}$, que a transmissão de significado feita pela expressão facial é central no cinema porque assim consegue comunicar sem palavras. $\mathrm{O}$

39 O cinema norte-americano consolidou-se como a narrativa fílmica clássica. Ismail Xavier ([1983] 2003) descreve esta narrativa como o tipo de ficção cinematográfica, produto da indústria, que tem mudado pouco, adaptando-se às novas demandas, às possibilidades técnicas e às limitações impostas pela censura. Este modelo de filme tem como base retórica a "impressão de realidade" (p. 11). Este cinema ergue-se como referência: filmes o contradizem, criticam, fundamentam, posições teóricas de pesquisadores e realizadores procuram alternativas e públicos exigem novas narrativas e alternativas de argumentos e personagens. Isto graças à sua esmagadora presença nas salas de cinema e ao desafio que impõe em termos econômicos, pela disputa de financiamento (editais públicos e privados) e de públicos (bilheteria) e ao fato de que é uma narrativa que consolidou as regras do "bom cinema".

40 Campo é a parte do espaço fillmico que é enquadrado e é visível na tela. O fora de campo é aquela parte do espaço que não é visível porque está além do campo. A questão de se o campo coincide com o quadro ou não é amplamente debatida, sendo que as relações entre visível, invisível e quadro foram se complexificando com o uso estratégico do som e de inserts, flashbacks, flashforwards, etc; elementos que quebram a sequência audiovisual e o argumento linear.

41 Nesta época eram produzidos filmes silenciosos. O primeiro filme sonoro, The jazz singer, do diretor Alan Crosland, estreou em 1927. 
homem interior ${ }^{42}$ é agora visível e as coisas tornam-se expressivas pelo enquadramento da face do homem. Jacques Aumont (1998) assevera que as imagens do rosto manifestam o mundo íntimo ou a afirmação da pertença a um grupo, por conseguinte são utilizadas no cinema com grande eficácia como signo que articula o individual e o coletivo, o personagem e o espectador. O rosto no cinema impede a percepção do personagem como uma figura fragmentada, a despeito do trabalho de enquadramento da câmera, e serve para produzir sentido e coerência pelo uso do olhar como vetor, ou seja, como direcionador das associações entre uma imagem e outra, no sentido e no significado.

$\mathrm{Na}$ cena inicial do filme, os planos do homem desmembram as mãos do corpo e impedem que seu corpo seja captado na totalidade. O corpo inteiro só é visto um instante, depois do zoom out sobre o ataúde, em um plano amplo e curto onde o homem entra, toma o ataúde com as mãos e fica escondido atrás - ou dentro - deste. O rosto é desfigurado pela ausência dos olhos, ocultos pelos óculos pretos. Escolha que contradiz a narrativa clássica, segundo a qual o enquadramento do ator, planos e movimentos de câmera que compõem sua ação e lugar, deve ser realizado de tal forma que consiga a identificação do espectador com a personalidade e o mundo do personagem. Isto, para que a linha entre ficção (da tela) e realidade (da sala de cinema) seja quebrada e o espectador participe do filme (ou do mundo fílmico, da diegese), completando seu sentido e seja afetado ${ }^{43}$ pela obra.

Neste sentido, a composição da intimidade da personagem de cinema seria feita pelo enquadramento detalhado e profuso do rosto. Assim, as regras do bom cinema seriam seguidas ao pé da letra e o filme seria um "bom filme". Mas a discussão não acaba aqui e a ideia da mimesis pode ser conjurada para complicar as coisas: "[...] Pela descrição detalhada ganha-se poder sobre a coisa descrita" afirma Taussig (1993); logo, a tela não seria mais uma janela aberta à realidade, seria o espaço que contém o poder da mimesis. O enquadramento do

42 O realizador russo Sergei Einsestein, desenvolveu reflexões sobre o monólogo interior e o close up neste sentido. Duas formas fílmicas que permitiriam ter acesso ao mundo interior, sensível, do personagem. O público poderia se aproximar da experiência do protagonista e assim sentir o choque emocional produzido pela imagem (apud. Xavier [1983]2003).

43 A questão da participação do espectador no filme, não será discutida neste trabalho, pois foge do tema central e exige um corpus de leituras e procedimentos metodológicos diferente daqueles aqui mobilizados. Mas, antes uma precisão sobre o tema: Edgar Morin (1956) desenvolve este assunto a partir das noções de presença objetiva da imagem (esta imagem é imagem de uma coisa real) e mobilização dos afetos do cinema (localização do espectador no lugar privilegiado, alvo e fonte de desejo). O antropólogo baseia sua reflexão no cinema de Hollywood, aquele de narrativa clássica (aristotélica), montagem linear (mimesis do espaço e do tempo real) e cujo ideal é produzir um cinema transparente, representação fiel da realidade, um cinema que não opõe posições contra esta afirmação. 
rosto significaria mais do que a construção da intimidade, porque o que estaria fazendo é construir a presença desse personagem. O problema aqui é que, apesar do rosto ser enquadrado, não nos é mostrado nada além do rosto-óculos e uma intimidade sem passado. $\mathrm{O}$ poder da mimesis de que fala Taussig, é um poder que a cópia rouba ao original porque esta parece ser igual sem ser o mesmo, tem todos os traços característicos e se oferece sem reservas à apropriação. É o poder da cópia que nos impele a acreditar na sua autenticidade e a fazê-la nossa. A imagem do Outro é uma forma de dominá-lo, mas também é uma forma de fazê-lo presente. O tipo de presença que o homem sem rosto expressa é a impossibilidade de estar presente, a invisibilidade que resulta do medo que inspira um ser que viola as regras.

Esta afirmação merece um breve exame. La sombra del caminante é um filme sobre o deslocamento forçado na Colômbia, sobre as pessoas que são obrigadas a se deslocar do campo à cidade por causa, principalmente, de ataques paramilitares, los desplazados. O antropólogo colombiano Alejandro Castillejo (2000) afirma que o desplazado é um outro não simplesmente porque é pobre e vive em condições difíceis nas cidades, diferente da população urbana, é um outro porque ele ocupa um lugar ambíguo nas cidades, presente e ausente, está lá, ocupa um espaço mas não há possibilidade de contato, nós (da cidade) o vemos, o ouvimos, sentimos seu cheiro, mas não o localizamos em um horizonte onde haja possibilidade de construção conjunta do mundo. São invisíveis, não porque fisicamente não estão, mas porque estando fisicamente presentes estão socialmente distantes (ibid., p. 124).

A Colômbia vive há várias décadas um estado de guerra interna na qual guerrilhas (extrema esquerda), paramilitares (extrema direita) e Estado disputam o poder sobre a terra e o controle da população civil e do governo, com o intuito de instalar um regime "mais justo", segundo cada uma dessas perspectivas (González et. al., 2002). Dado que as estratégias dos paramilitares seguem a lógica de contra-insurgência, desenvolvidas durante a guerra fria, o alvo de todas as ações é a população: a tese do "peixe na água" (guerrilha entre o povo) serve para justificar o deslocamento de pessoas para "tirar a água do peixe" (tirar a base social, o povo, do espaço de controle das guerrilhas) e enfraquecer o opositor, ou seja, a insurgência, as guerrilhas (Romero, 2003). O deslocamento forçado é hoje uma das consequências mais graves do conflito armado interno na Colômbia (Forero, 2003; Granada, 2008). O país ostenta as piores estatísticas em relação ao deslocamento forçado: hoje podemos contar uns 4 milhões 
de desplazados (em um país de 46.639.537 habitantes ${ }^{44}$ ), uma cifra maior do que as de países como Iraque, Afeganistão e Congo (Estadísticas..., 2012) ${ }^{45}$.

A ACNUR (Alto Comisionado das Nações Unidas para Refugiados) é a agência da ONU (Organização das Nações Unidas) para refugiados, criada em 1951, para “ajudar a reassentar os refugiados europeus que ainda estavam sem lar, como consequência da Segunda Guerra Mundial", e que desde então trabalha pelas necessidades das pessoas "deslocadas no mundo" 46 . Na Colômbia esta agência protege e ajuda "desplazados internos" (IDP pela sigla em inglês, Internally Displaced Persons) que "como uma reação natural ante as ameaças, fogem das zonas de conflitos ou das persecuções civis, como os refugiados" ${ }^{\prime 7}$. Esta agência não só define a categoria desplazado como indica o tipo de tratamento que deve ser oferecido a estas pessoas (menciono-a com intenção explicativa, ainda que superficial). A discussão sobre a definição desses sujeitos políticos excede o limite deste trabalho, podendo ser objeto de pesquisa posterior: as formas fazer ver e fazer entender a experiência do outro.

Para Castillejo (2000) a invisibilidade do desplazado, decorre da uma presença massiva em meios de comunicação e nos discursos de políticos e outros líderes que terminam por naturalizar a pessoa e sua situação. Mas, também é resultado do silêncio e das palavras utilizadas para se referir a estas pessoas, o que é uma forma de criar distância. Assim o outro se faz visível por meio de imagens ou representações inscritas em discursos e dispositivos, de modo que o conhecimento se torna a administração dessa distância (ibid., p. 112).

Mas também a invisibilidade resulta do lugar que a cidade e os agentes do estado têm disponibilizado para receber os desplazados: abrigos, lugar de refúgio. Castillejo chama a atenção para estes espaços de transição que se caracterizam pela ruptura de categorias de relação, identidade e história. É um espaço que dá tratamento policial aos desplazados que são, a partir desde momento, entendidos como problemas que questionam a ordem. É um espaço que se quer de ajuda, mas que segrega ou, melhor dizendo, coloca o desplazado em um lugar liminar, incerto e muitas vezes ininteligível para quem está fora, a sociedade que o recebe e que não tem outros espaços para essas pessoas.

44 Dados retirados de: http://www.dane.gov.co. Acessado em 08/2012.

45 Para mais informações e detalhes ver: http://www.verdadabierta.com/component/content/article/173estadisticas/3829-estadisticas-de-desplazamiento. Acessado em 07/2012.

46 ACNUR. Informação geral disponível em: http://www.acnur.org/t3/portugues/informacao-geral/ Acessado em 04/2012.

47 ACNUR. Desplazados Internos, disponível em: http://www.acnur.org/t3/a-quien-ayuda/desplazados-internos/ Acessado em 04/2012. Tradução minha. 
A opção de utilizar a palavra desplazado e não a tradução ao português, deslocado, indica uma proposta de pensar a palavra como marca de uma realidade. No caso argentino, o uso da palavra desaparecidos caracteriza as pessoas que desapareceram durante a ditadura e não outras, não as pessoas que, por exemplo, se perderam por crimes urbanos ou violência doméstica. Lembro aquela frase do informe "Nunca Mas": "[...] categoria tétrica e fantasmal: os Desaparecidos. [...] triste privilégio argentino! [...]" (CONADEP, 1984, p. 9, tradução minha). Desplazado não é só uma pessoa que sai do seu lugar de origem para se instalar em outro. É uma pessoa que abandona uma vida para inventar outra em meio ao desconhecido; é um problema social, uma categoria jurídica, alvo de ajudas e de múltiplas representações, uma imagem-pessoa que resulta do conflito armado interno. É alguém que carrega no corpo as marcas da violência colombiana: o corpo como texto, o lugar de inscrição da história, que pelo massacre perde sua subjetividade e se torna em um instrumento que carrega um símbolo (Castillejo, 2000, p. 24). É uma palavra que define um sujeito social, que apropriada pelas pessoas se torna uma forma política de agir, como mostra uma das entrevistadas pelo antropólogo Castillejo,

[...] Estamos lutando para manter essa identidade como pessoas e mostrar nossas regiões e nossos costumes. Estamos lutando para não nos deixarmos submergir nesse joguinho turbulento que se opera ao redor da população desplazada pela violência

Não será, que de repente essa palavra fosse inventada como quando se trada do tema da psicologia que são inventadas tabelas, que de repente viram que a palavra desplazado era abrangente, lhe cabia muita coisa e falaram vamos utilizar esta e vamos marchar com esta... (...).

[...] Desplazado é o que não vai parar, continua se deslocando de um lugar a outro até a última hora ou até cansar e tenha que voltar ao seu lugar de origem e ver o que aconteça (ibid., p. 144, tradução minha, grifos meus).

Com a cadeira nas costas e os óculos no rosto, o homem desce por uma rua estreita. Um close-up dos óculos que cobrem e exibem os olhos deste homem, cujo nome e voz não sabemos, faz um convite agressivo a olhar para ele ao mesmo tempo em que ameaça o lugar do espectador e seu poder de voyeur ${ }^{48}$. O fora de campo [o público] é observado e

48 Ismail Xavier (2003b) afirma que o protagonista do filme Rear Window (Hitchcock, 1954) é a ilustração da posição de voyeur: imóvel, grande investimento no olhar (tecnologia para olhar) e poder de ver (sem ser visto). Slavoj Žižek (2009) comenta o caso do olhar ausente em uma crítica feita ao cinema de Hitchcock. Este olhar é uma entidade impossível de encontrar na realidade cotidiana (o objeto ameaçador devolve o olhar), é fantasmático, mas dá corpo a essa impossibilidade. O que atrai o fascínio é esse olhar imaginado/inexistente que observa a partir de um lugar de subjetividade impossível. 
permanece ignorante desse ato. O homem chega ao centro da cidade e se detém perto de um letreiro que diz "carrera 7" - aquele que fica do lado da Catedral Primada de Bogotá, um lugar central na geografia urbana e na história da cidade ${ }^{49}$.

O homem imóvel e desorientado olha para as pessoas que andam pela rua ${ }^{50}$. O plano geral enquadra durante alguns segundos o corpo do homem com a cadeira nas costas e os óculos no rosto, ao que segue um plano subjetivo que mostra o objeto do olhar do homem. $\mathrm{O}$ corpo do homem não só adquire unidade e sua figura se torna concreta para o espectador, como sua visão é revelada, o espectador assiste à declaração da mais íntima individualidade, o objeto e a intenção do olhar. Assim, exibido e objetivado pela imagem, este olhar se torna acessível e dá conta de uma dimensão muito mais profunda do que o nome ou a história de vida antes reclamadas para descrever este homem. De modo que, pensar o olhar como vetor neste filme não significa pensar nos usos estratégicos de direção e continuidade (raccord ${ }^{51}$ ), antes, sugere que há uma construção do personagem por meio das suas visões das pessoas e da cidade que agora habita. Sugere também que o espectador é obrigado a se identificar com o personagem pela sobreposição dos pontos de vista executados pelo plano subjetivo, pouco tempo depois do começo do filme, quando ainda o personagem é uma imagem, sem nome, sem história e sem desejos. E mais, o plano subjetivo do homem parece impossível já que é um plano de um olhar coberto, mostra disto é a imagem sem foco, lenta, pesada, cujo fluxo parece dificultoso e acompanhado por um som denso, que descreve este olhar.

Um primeiro e curto plano deixa ver uma mulher que se detém a observá-lo. Outro plano mostra duas moças que passam e olham para ele, o homem continua imóvel. Em seguida, em câmera lenta imagens altamente contrastadas, planos de pessoas que atravessam a rua em um sentido e carros no outro. O som é estranho, um barulho inidentificável e uma

49 Construída entre 1807 e 1823, a Catedral é o centro religioso mais importante na Colômbia, está localizada na Plaza de Bolívar, ponto de encontro de festas (a abertura do Festival Iberoamericano de Teatro, o final da Marcha del Orgullo Gay), manifestações políticas (discursos de Jorge Eliécer Gaitán na década dos anos 1940, dos partidos políticos liberales, conservadores, de esquerda, de movimentos sociais, ponto final das marchas políticas), ataques guerrilheiros (Toma del Palacio de Justicia no dia 6 de novembro de 1985 pelo M-19) e "cartão postal" de Bogotá.

50 Ele está em frente à Casa del Florero (lugar onde, segundo os historiadores, ocorreu o começo do processo de Independência) ao lado da avenida séptima, eixo viário da cidade e cenário principal do filme.

51 Encanamento entre plano e plano. Técnica de montagem que apaga mudanças de planos, existem três tipos: eixo (espaço), movimento (estético) e olhar (diegético), cada um dos quais se preocupa com a manutenção da continuidade. (c.f. Verbete raccord em: Aumont e Marie, [2001] 2003). 
batida curta que se repete e sobressai dentre os outros sons, parece uma vibração que termina com um eco e recomeça. No roteiro o som desta cena, está descrito assim: "o barulho da cidade é baixo, como o de um monstro dormindo" ${ }^{52}$. Finalmente, vemos pessoas que vendem balas e cigarros na rua. Ele observa em silêncio, sério, sem emoção e coloca no pescoço uma pequena bolsa branca, tecida a mão, colada a ela um letreiro de papelão que diz, em uma letra quase infantil: “passagem \$50”.

O rosto é público e serve para se posicionar diante dos outros e de si mesmo, ele organiza e informa os distintos tipos de relação social. O olhar do homem da cadeira é um que não pode encontrar o de ninguém, é ausente e ao mesmo tempo é uma fonte de poder, vê sem ser visto. Nos planos que se seguem, irão se alternar imagens subjetivas, estilisticamente iguais à primeira, e imagens do homem caminhando. Esta sequência tem o caráter de apresentação das relações do homem com seu entorno. As pessoas o olham com estranhamento e se afastam (até um cachorro evita seu encontro), e ele parece desinteressado pelo mundo ao seu redor. O som da voz das pessoas que vendem mercadorias na rua, bem como do barulho de ônibus e carros, destacam estas imagens de outras similares. A sensação é a da marginalidade deste homem, sua diferença em relação ao resto da população da capital. Existe alguma coisa que impede este personagem de se aproximar dos outros. Vemos que seu contato com as pessoas tem algo de heterodoxo e habitual: a cadeira que foi construída na sequência anterior serve para transportar pessoas de um lado para outro. É um tipo de trabalho informal que se desenvolve nas ruas; neste sentido, é cotidiano em uma cidade com altos índices de desemprego ${ }^{53}$, que recebe imigrantes - desplazados, pessoas à procura de trabalho, educação, mas em qualquer caso, imigrantes internos, se deslocam dentro do país diariamente sem conseguir mudar, a curto prazo, sua estrutura para incluir estas pessoas. Os óculos estabelecem uma barreira intransponível, é um objeto que causa estranhamento e propõe o contato pela negação, o intercâmbio de serviços sem encontro. É como se o homem

52 No roteiro: "el ruido de la ciudad es leve, como un monstruo dormido". (Guerra, 2001 cena 2 ).

53 Segundo o DANE (Departamento Administrativo Nacional de Estadística- www.dane.gov.co) o desemprego em maio de 2011 era de 11,3\%. Na cidade de Bogotá a porcentagem de desemprego é de 9,9\%. ("Los sectores comercio, hospitalidad y servicios comunales y sociales cuentan com el mayor número de empleados" em: www.noticias.elempleo.com Acessado em 08/2011). Desta porcentagem, uma grande parte é emprego informal, assim no mês de março de $2011,50,9 \%$ da população empregada tem um trabalho informal. Na cidade de Bogotá o 45,5\% da população com emprego, tem um trabalho informal. ("El DANE reveló nuevas cifras del panorama laboral, em el que se refleja que la mitad de los empleos del país son informales." Em: http://noticias.elempleo.com/colombia/noticias laborales/la-informalidad-sigue-subiendoen-colombia- 9315140. Acessado em 08/2011. 
existisse para os outros enquanto alguém que serve (meio de transporte) ao mesmo tempo em que viola as regras de comportamento, por isto, tem sua inserção na dinâmica da cidade pelas margens, como um ser invisível. No entanto, parece ainda a estratégia que o próprio homem desenha para estar nessa cidade: ele construiu a cadeira e ele vestiu os óculos, nada disso lhe foi imposto.

Por outro lado, este primeiro trajeto pela avenida séptima tem também o caráter de apresentação do lugar, o espaço onde a história acontece. Sabemos que a história do filme se desenrola no tempo presente e em uma cidade altamente urbanizada. A sequência, construída por distintos planos do homem e planos subjetivos, expressa o tipo de relação que o homem tem com a cidade e particularmente com o centro histórico de Bogotá (os trajetos habituais são pela rua séptima entre ruas $7^{\mathrm{a}}$ e 26). Uma relação distante e silenciosa, na qual o serviço que oferece o homem da cadeira e a necessidade de se deslocar dos pedestres cansados, preguiçosos ou com problemas de locomoção, entrarão em contato. Estes são planos que apresentam Bogotá, seus habitantes, o tipo de transporte público, a estética da rua, o desemprego e as soluções criativas para este problema, a música, os vendedores de rua. Seu ritmo e seu sentir localizam o espectador em um lugar real, reconhecível; embora não haja planos de endereços ou de letreiros - vemos um único plano, "carrera 7" - que confirmem a existência desse lugar e o percurso nele, as imagens têm a qualidade de guiar o espectador pela cidade, descobri-la e configurá-la ao mesmo tempo em que o faz o homem da cadeira.

Esta parte da cidade é um local em que outras vezes foram encenados filmes. Certos usos da cidade podem ser comparados ao uso que faz Ciro Guerra. Uma comparação pode ser estabelecida com o filme de Jaime Osorio Gómez ${ }^{54}$, Confesión a Laura (1991), que se desenvolve nos dias seguintes ao "Bogotazo" "55. As imagens do início do filme são citações do noticiário filmado pelos irmãos Acevedo nestes dias, o som é construído a partir de uma coleção de fragmentos de um famoso discurso pronunciado pelo líder político Jorge Éliecer Gaitán na Plaza de Toros la Santamaría no ano de 1946. A Bogotá apresentada nos primeiros minutos do filme de Osório é a de um lugar escuro, destruído, onde pessoas vestidas de gabão

54 Jaime Osorio Gómez entrou ao final da produção e montagem do filme, quando, segundo Ciro Guerra, este se encontrava em um momento de "confusão narrativa", segundo disse ele em entrevista realizada em Bogotá no mês de fevereiro de 2011.

55 O "Bogotazo" ocorreu no dia 9 de abril de 1948, por conta do assassinato o líder político Jorge Éliecer Gaitán. Tal acontecimento desencadeou uma série de eventos violentos, como o assassinato de conservadores e liberales (pessoas associadas ao partido), saque de lojas, incêndio de carros e vandalismo na cidade de Bogotá, daí o nome. 
e chapéu escuro correm de um lado para outro em uma grande confusão pelo centro da cidade. No decorrer do filme, a cidade desaparece para dar lugar à história íntima que se desenvolve no apartamento da personagem feminina. No apartamento, Bogotá e o caos que reinava entram graças ao som da rádio ${ }^{56}$, que é ligado só nos momentos de angústia para escutar as notícias, se informar sobre o a situação presente, e para tomar decisões sobre seu futuro imediato. Uma encenação que cria um ambiente pesado, onde a cidade é um lugar que ameaça e o apartamento não protege de tal perigo, embora para os protagonistas fechar a porta e as janelas seja uma garantia de segurança. A cidade de Confesión a Laura e a cidade que Ciro Guerra apresenta compartilham ${ }^{57}$ a característica de ser um lugar difícil, no qual as pessoas correm de um lado para outro para sobreviver, ora para escapar da violência, ora para trabalhar informalmente e fugir dos policiais. Bogotá ${ }^{58}$ assim se torna mais do que uma locação, um cenário: é um elemento que define as características das personagens e seus trajetos.

Esta relação dominada pelo silêncio e pelo desencontro é sutilmente alterada quando o homem da cadeira, ao se aproximar de uma venda se detém, para ver a mercadoria, ao lado de uma pessoa com muletas que, surpreendida, olha para o rosto deste personagem, em seguida para o preço no papelão e pede seu serviço com um gesto. O homem da cadeira carrega o primeiro passageiro, seus pés são enquadrados por um close-up, seus passos rápidos e seguros são marcados pelo som do caminhar que se distingue dos outros barulhos da rua. Um enquadramento amplo do homem trabalhando na calçada e um fade out $t^{59}$ pontuam o final desta sequência que termina com o título do filme.

Aos poucos a tela clareia, um travelling ${ }^{60}$ da direita para esquerda mostra alguns

56 Estes anúncios de rádio são os mesmos que foram transmitidos na época, narrados por Arturo Álape, importante jornalista, historiador e pesquisador colombiano.

57 A aproximação que proponho entre os dois filmes não quer indicar que o resultado do filme de Guerra se deva à intervenção de Jaime Osório. Este colabora com algumas soluções narrativas e de montagem que foram importantes para terminar o filme. $\mathrm{O}$ interessante é notar a forma como a cidade aparece nestas duas obras.

58 O jornal el Tiempo, publicou no dia 8 de abril de 2005, um artigo onde se afirma que: "O cinema tem uma grande dívida com Bogotá. A cidade tem os elementos da Paris de maio de 68; da Roma de pós-guerra; da Cidade de México de Buñuel, afirma Ciro. Muitas pessoas, ao redor do mundo, depois de assistir o filme têm me dito: Bogotá é uma cidade muito interessante, e isso, porque não existe nada parecido, e porque não se lhe tem feito justiça. É um convite a filmar a e na cidade, a descobrir seus lugares cotidianos e extraordinários” (Bogotá..., 2005 )

59 Escurecimento gradual da imagem partindo de uma intensidade normal de luz.

60 Câmera em movimento. Qualquer deslocamento horizontal da câmera que acompanha, por exemplo, o andar das personagens. 
objetos sobre uma mesinha: óculos, um cachorro de cerâmica, atrás um rádio, ao lado figuras de papel, uma caneca com marcadores e ao lado um círio, no fundo o contorno da janela aberta que deixa ver um muro de tijolo. De repente, uma sombra que precede um braço coloca a estátua de uma virgem sobre a mesa e mãos acendem uma vela com um fósforo. Agora vemos um homem magro ajoelhando-se com dificuldade. Ele veste uma blusa branca e um colar de pequenas imagens de santos, os poucos cabelos que lhe restam são pretos, o rosto sério, marcado por rugas, boca fina, olhar grave e triste. Com voz baixa, o homem diz: "Bom dia, pequena virgem!”, faz o sinal da cruz e olhando seriamente em direção a virgem, reza: "Me ilumine hoje, porque talvez amanhã a gente não esteja mais" ${ }^{\text {" }}$. A resposta, um contra-plano do olhar da virgem e do filho Jesus, inexpressivos, frios como o material do qual foram construídos. Um close-up mostra a mão do homem pegando os óculos que tínhamos visto antes e os vestindo. A câmera segue o movimento e se afasta para enquadrar o homem de costas agora pensativo. Este gesto é perturbado por alguém que bate em sua porta, o homem se apoia em um bastão e caminha com dificuldade até a porta do quarto.

Trata-se de uma mulher de uns quarenta anos, gorda, de cabelo até os ombros, o rosto cansado, sério e expressivo, de olhos, nariz e boca grandes. Ela veste uma blusa branca com gola em forma de V enfeitada com um tipo de renda e uma blusa de lã. é Doña Marelvis, dona da casa onde Mañe ${ }^{62}$ mora. Ela, em tom de voz cansado de repetir o mesmo pedido, cobra o dinheiro do aluguel. Escuta com um gesto também cansado de ouvir a mesma resposta: hoje eu procuro o dinheiro, hoje eu consigo trabalho, palavras pronunciadas sem esperança, como um pedido para não ser mais cobrado, como uma promessa de alguma coisa impossível. Enfim, cansaço na repetição da solução do Sargento, o irmão de Doña Marelvis: vai para o abrigo onde será acolhido e cuidado, porque é lá onde as pessoas como

61 Todas as traduções dos diálogos são minhas, as versões originais em espanhol são transcrições do áudio do filme.

62 Os atores que encarnam Mañe e Doña Marelvis são dois grandes artistas cujas biografias incluem atuações em teatro, televisão e cinema. César Badillo (Biografia no site www.proimagenes.com.co) é Mañe, ator do Teatro la Candelaria (fundado em 1966, por pessoas que vieram do teatro experimental e do movimento cultura. Mais informações em www.teatrolacandelaria.org). Em 1985 começou a trabalhar no cinema, em curtas e longas metragens de diretores como Felipe Aljure, Luis Ospina e Lisandro Duque e em 1989 ingressou no mundo da televisão. Inés Prieto, foi atriz do Teatro La Mama [fundado por Kepa Amuchastegui na década do anos 1970, com afinidade da linha experimental do La MaMa Experimental Theatre Club de New York], e participa do grupo do Teatro La Candelaria. Esta atriz participou da reconhecida série de televisão Los victorinos e de filmes como Cóndores no entierran todos los dias (1984) de Francisco Norden. Estes dois atores que já tinham se encontrado em montagens de teatro, trazem para o filme rostos familiares e dão ao filme um peso importante na atuação. 
ele-deficientes físicos, pobres, desempregados e sem família - vão.

Óculos para enxergar melhor, óculos para ocultar os olhos, olhares graves, olhares tristes, olhares cansados e olhares inexpressivos. A ênfase dada nas duas sequências de apresentação das personagens aos olhos e os artefatos utilizados para melhorar ou ocultar a visão indica que um dos eixos do filme é o olhar e, justifica a opção de descrever o filme atentando a este ponto, as formas de olhar, olhares projetados sobre pessoas, situações e lugares, olhares desfocados ou ausentes. E se o olhar é tão presente, a identidade e a personalidade das personagens parece difícil de caracterizar. O homem da cadeira não tem nome, somente diz seu apelido perto do final do filme durante uma conversa com Mañe. Porém, ao ser um nome que deve ser esquecido, não é uma forma de identificar o personagem. Ele nem sequer tem um título que possa colocá-lo em um oficio: secretário, funcionário, policial, vendedor, condutor. Em oposição, é um personagem que tem uma forma clara de se pôr em cena, tanto nas falas, quanto no vestuário e na decoração que o acompanha. Da outra personagem conhecemos o sobrenome, "Mañe", mas não seu nome, e apesar disso sabemos detalhes sobre seus problemas e possibilidades. O Sargento Osvaldo Jaimes é apenas mencionado e Doña Marelvis mostra-se inquieta como querendo fugir da presença de Mañe. Assim, neste ambiente vazio, as relações entre as personagens é implícita nos jogos de montagem - como no caso do homem da cadeira que carrega pela rua um homem coxo de óculos - e o mundo subjetivo de cada um é profusamente apresentado por meio dos planos de olhares e dos planos subjetivos.

O rosto, conforme Taussig, é a "[...] aparência da aparência, figura da figuração [...] em si mesma é uma contingência no cruzamento mágico de máscara e janela à alma, um dos segredos públicos melhor guardados e essenciais à vida cotidiana" (1999, p. 3). Com o cinema, o rosto se tornou uma forma-paisagem que expressa o mundo íntimo e o estado das coisas no ambiente e que, como adverte Aumont (1998), vem sendo destruído pelo cinema que se interessa pelos limites da comunicação e da expressão, e que ao mesmo tempo deixa de enquadrar o rosto como tipo, amostra de uma coletividade, e começa a mostrar as particularidades do indivíduo. É interessante perceber que este indivíduo, ao não se configurar como um representante de um coletivo nem expor qualidades morais, é o indivíduo marginal, aquele cujo rosto e cujas paisagens ainda não podem ser imagens de cinema. 
A conversa entre Mañe e Doña Marelvis apresenta temas que constituem o pano de fundo do filme: o desemprego, as dívidas, as criativas soluções à situação precária e o sempre presente discurso para ir à um abrigo. Uma música triste acompanha Mañe na rua, seu olhar para frente. O terno cinza e gravata listrada e o esforço para andar pela rua apresentam uma pessoa solitária e forte, independente. Seu caminhar é interrompido por três jovens que antes conversavam animadamente e que ao encontra-lo fazem piadas sobre sua perna artificial. Eles, diante da ameaça raivosa de Mañe, que empunha o bastão e olha diretamente para eles, atacam-no. A agressão é surpreendida pelo homem da cadeira. Planos curtos, médios e primeiros, vinculam os olhares e os espaços que cada um ocupa, até ressaltar o olhar assustado de Mañe, finalmente um plano profundo do homem que, indiferente, continua seu caminho. Os jovens intimidados tentam ajudar sua vítima, ato que é suspendido pelos gritos e maldições de Doña Marelvis contra estas pessoas. Ela tenta ajudálo, mas este se nega, querendo se mostrar forte e autossuficiente, um traço particular da pessoalidade deste personagem.

Um close- up de uma nota de \$10.000 (R\$10,oo) é agressivamente recebida e guardada em uma gaveta. Mañe está em um escritório de uma agência de emprego, desconfiado paga a taxa, faz algumas perguntas sobre as possibilidades para uma pessoa na sua condição ser empregada, sobre o exame médico e o currículo. Seu nervosismo encontra a ironia da atendente que se limita a responder: "Nós lhe conseguiremos trabalho mesmo se você é coxo, manco, surdo, mudo e feio". Na cena seguinte, um pastor orienta as preces do grupo que desesperadamente se aproxima de todas as possibilidades de conseguir um emprego, mesmo que elas sejam fúteis, como Mañe, irritado, descobre. Desanimado, Mañe para em um ponto no Parque de Santander ${ }^{63}$, onde ele tenta vender figuras de origami. A mercadoria está disposta em uma caixa de papelão com um letreiro: "apoie a arte $R \$ 0.10 ”$. Em oposição à situação de Mañe, o homem da cadeira trabalha durante todo o dia, leva pelo centro

63 Este lugar, antes chamado "plaza de las hierbas", está localizado no cruzamento da carrera 7 com a calle 16 , atualmente, ali se encontram o Museo del Oro, e o Edificio Avianca. Prédios famosos, um pela coleção de peças pré-colombinas em ouro e o outro pelo incêndio de 1973 que acabou com um dos prédios mais altos da cidade naquela época. Nesta praça encontra-se também a estátua de Francisco de Paula Santander, general que participou das lutas pela independência e liderou a criação da República e outros monumentos como as igrejas de San Francisco, de Veracruz e de La Tercera (Instituto Distrital de Patrimonio Cutural, 2008). Além disso, neste lugar se encontra o símbolo da modernização do país, o prédio do Banco de la República; instituição criada em 1923 (história do banco disponível em: http://www.banrep.gov.co/el-banco/hs_1.htm. Acessado em 04/2012). 
estudantes, fumantes e gordos, à tarde se protege do sol com uma sombrinha e às 6:15h ele vira o letreiro onde está escrito o preço da passagem que agora contém a seguinte mensagem: "fora de serviço".

Chama a atenção o tempo dedicado à apresentação do caminhante (quase quatro minutos) em contraste com o tempo em que a câmera foca Mañe (quase oito minutos). Os planos que enquadram o homem da cadeira são gerais e, na sua maioria, pouco profundos, de modo que ele aparece como sendo parte da cidade e do seu movimento, como colado a ela; os planos fechados mostram seu rosto, seu caminhar, seu cansaço, seus passageiros e as atitudes deles. Ao mesmo tempo é um marginal porque seu silêncio e sua aparência o distanciam, e porque a única relação que estabelece com as pessoas é curta e mediada pelo dinheiro ${ }^{64}$. Em contraste, Mañe é construído por meio de planos abertos e distantes, que fazem dele um pequeno elemento dentro daquela cidade. Nos dois casos a situação presente é construída a partir das relações com as pessoas mais próximas e com o mundo do trabalho. $\mathrm{O}$ mundo das personagens é apresentado e se torna evidente que o homem da cadeira tem pouco tempo na cidade, enquanto Mañe mora há algum tempo, já é conhecido por outros moradores, tem uma rotina no bairro e trajetos pela cidade, tem dívidas e tenta pagá-las. O tempo na cidade os diferencia, mas, é claro que eles não são de lá e que não estão morando ali por vontade própria.

Desta forma, é construída uma relação por oposição entre estas duas personagens, o que cria um vínculo de complementaridade e não de disjunção. Um traço específico os une: o tipo de trabalho que fazem não existe; se bem que, em uma cidade como Bogotá, com altos níveis de desemprego, é comum ver pessoas na rua vendendo todo tipo de mercadorias ou fazendo todo tipo de atividades. Transportar pessoas em uma cadeira portada nas costas ou vender figuras de origami não são, de fato, formas de ganhar alguns centavos dia após dia. "É um

64 A mediação pelo dinheiro na sociedade colombiana é levada ao paroxismo por Felipe Aljure nos seus dois filmes: La gente de la Universal (1994) e El Colombian Dream (2006). No primeiro filme, a troca de notas por favores é o que permite as personagens continuarem seu trabalho e esconder dos colegas/familiares as faltas e os erros de forma que as relações amicais não se firam. No segundo filme, a circulação de LSD (ácido lisérgico) amarelo, azul e vermelho (as cores da bandeira colombiana) é permitida em todos os lugares porque sua presença é automaticamente traduzida em ganhos econômicos. As cores da droga são uma forma irônica do diretor evidenciar a "cultura nacional" que permite certa liberação das relações com o narcotráfico, no caso do filme, porque estas estão mediadas e justificadas pelo dinheiro. Este tipo de usos dos ícones nacionais é caro a alguns diretores que pretendem criticar situações cotidianas e aceitadas pela familiaridade que as cobre. 
filme absurdo mas as pessoas acreditam nele", como chegou a afirmar o diretor na ocasião de uma entrevista feita para a revista Kinetoscopio, mas, sobretudo, continua o diretor, "as pessoas veem o seu cotidiano transformado, como algo mais do que um registro e exatamente um registro do presente da carrera 7 e de seus transeuntes" (Figueroa, 2004, p. 62).

Sendo este um filme que elabora uma questão sensível como o deslocamento forçado e se preocupa em mostrar as condições desta existência, como é possível afirmar que é um filme absurdo? Existe um cuidado na construção da personagem do homem da cadeira: usa óculos escuros, leva pessoas em uma cadeira de madeira que carrega nas costas - uma cadeira que foi o resultado da transformação de um ataúde -, é misterioso (não revela nem seu nome nem seu passado), realiza um trabalho por um preço irrisório (Rs 0,05 ) e que aumenta só depois de carregar um homem gordo, mas que continua sendo um ganho insignificante (Rs 0,50), carrega uma planta que serve para fazer um chá que tem um gosto desagradável e mora em uma barraca construída de plástico preto em uma colina de Bogotá. Absurdo é a palavra que utiliza o diretor para descrever o filme, ou seja, seria uma obra que é "contrária ao bom senso, à razão, ao costume ou a qualquer tipo de verdade ou modelo estabelecido", se seguimos a definição do dicionário da língua portuguesa (Aurélio, 2004). Mas isto continua sem resolver a interrogação.

A personagem do homem é "contrária ao bom senso", mas é real, não é um tipo de existência que não possa chegar a ser, se as condições assim o exigirem. O valor que ele põe ao seu trabalho autorizaria uma leitura moral da ação: expiar a culpa pelo sacrifício, a redenção final. No filme não é possível o perdão nem o esquecimento. A relação entre Mañe e o homem da cadeira é de solidariedade e de silêncio, eles só estão presentes - e esta é a condição para o encontro se tornar troca e amizade. Esta personagem do homem da cadeira pode ser pensada como uma alegoria de um problema existencial, ela torna visível não uma coisa física e sim uma experiência que não é palpável (é mostrada graças a/pela linguagem fílmica, no caso). O absurdo da imagem, não estaria na ausência de razão, e sim em um tipo de razão capaz de conceitualizar a situação como absurda, para então chamar a atenção sobre ela. Sem ser explicação, o filme pode chegar a constituir uma pausa e um deslocamento das formas de pensar sobre os desplazados e seu mundo.

As conceituações sobre cinema compreendem posições que vão do uso da câmera como instrumento para observar detidamente a realidade até a configuração do imaginário. Ismail 
Xavier afirma que as diversas posições dizem "respeito ao modo de organizar a imagem/som, tendo em vista a realização de certo objetivo sócio-cultural tomado como tarefa legítima do cinema" (2005, p. 14). Desta forma, observam-se duas formas que o cinema tem desenvolvido para se adequar ao que lhe é proposto: o registro fiel da realidade e a construção crítica de uma imagem da realidade. Xavier (ibid.) observa que estas propostas não são exclusivas e cada uma é, sobretudo, um discurso sobre a opacidade ou a transparência da imagem. Transparência é a estratégia de ocultar o dispositivo, a opção pela continuidade, a naturalização dos diálogos e dos gestos, a mimesis do tempo e do movimento, uma organização dos elementos que manipula o interesse do espectador e mantém a integridade do fato representado para ocultar a montagem, busca "montar um sistema de representação que procura anular a sua presença como trabalho de representação" (ibid., p. 41). Opacidade seria então, a opção por mostrar o dispositivo, o corte, a declaração da descontinuidade, sem preocupação pela unidade temporal, espacial ou mesmo da estória, que tenta "liberar o objeto da nossa visão utilitária" (ibid., p. 108), propor "formas de organizar a experiência fora dos quadros naturais" (ibid., p. 117) e debate a questão do cinema como discurso ou como ponto de vista, sempre ressaltando a sua capacidade de produzir conhecimento.

O problema não é de mais ou menos realidade da imagem e sim dos discursos que a validam como mais ou menos verdadeiro, como mais ou menos expressiva do mundo social. É esta última afirmação que me interessa, pois a imagem é liberada das condições do registro fiel para que possa se tornar uma forma expressiva que pode imaginar, deslocar, reestruturar o original e, como diria Walter Benjamin, se tornar uma iluminação profana, que mostre desvios perturbadores, a inscrição de analogias impossíveis, a abertura de espaços inconfortáveis que coloque o espectador em lugares extraordinários para obrigá-lo a pensar (Benjamin, [1941] 2010). De modo que o interesse, como ressalta Morin (1956), pela imagem de cinema que mostra o cotidiano para um público que se maravilha ante uma imagem de si mesmo, desloca-se para a imagem que mostra um cotidiano marginal, a cotidianidade de um outro, uma narrativa não oficial da história. E mais, é uma imagem que ao expressar este cotidiano-marginal desloca-o e perturba o olhar que se tem sobre o mundo do outro. É o que acontece com as imagens de trabalho que Guerra apresenta no filme, ele não só mostra formas de trabalho informal, ele mostra formas impossíveis (carregar pessoas pelas ruas de Bogotá em uma cadeira nas costas) e até radicais (vender figuras de origami), diferentes do trabalho informal que consideramos convencional, como malabaristas, vendedores de livros, de 
artefatos de uso doméstico ou de filmes.

O cinema é uma forma da sociedade narrar a si mesma (Hikiji, 1998). A elaboração de um filme exige reduzir a fragmentos para melhor controlá-los e organizá-los. É um processo de elaboração que mistura elementos narrativos (herói, assunto, tema, conflito, etc.) e nãonarrativos (fade, superexposição, sobreposição, close-up, inserts, etc.). Esta construção de mundo pela filmagem e montagem de sequências de imagens e sons, diz respeito à apropriação do outro pela cópia de que fala Taussig (1993). Seria a forma moderna de "prender algo pela sua semelhança" (ibid., p. 21), e que desencadeia um processo no qual se envolve o percebido e quem percebe segundo as leis de cópia e contato que dão lugar a um conhecimento corpóreo do outro. É a extração do desconhecido para ser apreendido e inserido no nosso mundo.

Diante de uma realidade que se mostrava perigosa, cruel e desmoralizante, Benjamin ([1936] 2010) encontra na narrativa oral a forma ideal para comunicar experiências de extrema violência, em oposição ao romance e à informação, formas de comunicar que careciam da capacidade de criar uma experiência coletiva, porque se fundavam, a primeira, no indivíduo isolado, e a segunda, na novidade. A narrativa se mantém vigente graças a sua forma oral e à ausência de explicações, e assim tem a faculdade de fazer o ouvinte se esquecer de si mesmo e de espantá-lo, levá-lo à reflexão. O esquecimento assegura a rememoração e a surpresa, grava as histórias na memória para que sejam apreendidas e contadas outras vezes. Em resumo, a narrativa tem a faculdade de intercambiar experiências. Nesse sentido, a narrativa teria a possibilidade de estabelecer um espaço onde as definições do comum seriam constantemente discutidas, reformuladas, recriadas.

A afirmação de Taussig (1986) de que a maioria de nós conhece o terror pela narração coloca o problema da mediação e da escritura empregadas para comunicar efetivamente tal experiência. Sendo que o interesse não é fornecer dados, números e explicações, mas de fazer existir a intimidade do terror na experiência coletiva. O objetivo seria então construir histórias que surpreendam, que não permitam nos acostumarmos ao terror, suas formas e consequências. A questão que coloca o antropólogo é a de como escrever efetivamente contra o terror, comunicar sua dimensão incomunicável, sua parte da experiência do vivido e elaborado dia a dia, boca a boca, sem expandir suas vitórias: o silêncio, o medo, a aceitação passiva. Deste modo, a narrativa se pensa neste trabalho como forma que articula o 
inarticulável, o dessemelhante; cuja faculdade de intercambiar experiências nos leva a pensar nas formas de comunicar o terror.

A narrativa incorpora a experiência, a própria ou a que conhece por meio do que é narrado por outros, o terror é aquilo a ser narrado para retirá-lo das redes de informação rápida e superficial. $\mathrm{O}$ cinema como narrador moderno subtrai o espectador da cadeira para pô-lo em contado com o desconhecido, com a morte, com o impossível, mas também com os desplazados, os desempregados, os deficientes físicos, os miseráveis que deambulam pelas ruas. A narrativa fílmica tem se desenvolvido a partir de grande liberdade criativa, com formas que não respondem aos cânones da informação plausível, que quebram o ideal do realismo da ficção clássica e que, simplesmente, logram reunir elementos diversos ou até divergentes. Um filme, como não está comprometido à tarefa de dar conta da realidade, do modo como um noticiário, um jornal ou até um romance, constrói imagens do sensível, do inefável. Assim, diante de um filme como este, posso começar a estranhar as ruas da minha cidade de natal, a repensar sua geografia e sua população atual, e sou obrigada, sobretudo, a rever os conceitos que tenho sobre o deslocamento, as vítimas, o desemprego, as formas de sobreviver, de alucinar, de rezar e de ter esperança.

Um plano aberto da cidade à noite, prédios e casas iluminam a paisagem com luzes que tilintam. No primeiro plano, uma pequena árvore e no fundo a escuridão, uma lamparina é acesa e a luz tênue aclara o interior de uma pequena barraca construída nas colinas que circundam a cidade. Em planos fechados vemos a preparação de um chá, feito com as folhas de uma planta desconhecida, que o homem bebe antes de dormir. Na sequência, um plano frontal amplo de Mañe ainda na praça - agora aos pés da estátua de Francisco de Paula Santander, herói da independência colombiana - que está vazia. Chove, algumas pessoas passam com guarda-chuva fugindo do frio e das gotas de água que caem. Diante desta visão, Mañe joga a caixa no chão e guarda no bolso do seu paletó as figuras de origami que não vendeu.

Mañe chega em casa, está desanimado e procura forças para ir ao quarto, o som do bastão e do pé encontram a voz de Doña Marelvis, que, agitada, anuncia a presença do Sargento Osvaldo. Um homem bêbado se aproxima devagar, apoiado em um bastão, cambaleando se detém na frente de Mañe e em um tom ameaçador cobra o dinheiro do 
aluguel. E Mañe oferece algumas notas que não parecem ter valor alto por conta da resposta irritada do Sargento. Insensivel, o Sargento afirma que Mañe nunca encontrará trabalho, nunca terá dinheiro para pagar os meses de aluguel que está devendo. Os planos fechados que constroem esta interpelação violenta do homem de óculos, bigode e cabelos pretos, parecem construir um jogo de espelhamentos no qual, Mañe se reflete no Sargento, e ele em Mañe. Duas pessoas de características similares com posições e destinos opostos. Finalmente, o Sargento, que já ganhou o desprezo do público, revela algo do passado de Mañe, um detalhe de sua biografia que motiva seu ódio, o qual é razão suficiente para querer enviá-lo ao "asilo" " "porque lá só chega a escória, os aleijados, coxos, inválidos, deslocados como você. Vai embora! Vai embora!"

O Sargento revela a condição de desplazado de Mañe, com isto, ele deixa de ser mais um desempregado nas ruas de Bogotá, e passa a ser alguém que carrega uma história de violência e morte que marca suas relações com a cidade e os demais habitantes. $\mathrm{O}$ deslocamento forçado é para Ciro Guerra o tema principal do filme. Em uma entrevista realizada em Bogotá, em fevereiro de 2011, o diretor afirmou que ao chegar à Bogotá, ele, um cesarense $^{66}$, surpreendeu-se com a visão dos desplazados que estavam na rua e inspirou-se para escrever o roteiro do filme.

No dia seguinte, com um televisor na mão e certa desconfiança no andar, Mañe começa a descer pela rua. Os jovens que antes haviam atacado o personagem aparecem de novo. Uma série de fades out e in mostram o roubo agressivo da televisão e o momento do encontro de Mañe e o homem da cadeira. Agora, deitado, adormecido, sofrendo e com manchas de sangue no rosto, Mañe recebe os cuidados do homem e acorda para vê-lo descer pela colina. O homem deixa Mañe na barraca e retorna à cidade, um dia de trabalho com mais passageiros, encontros com malabaristas e vendedores de rua, perturbado por um encontro com a polícia que ameaça tirar sua cadeira. A polícia pede a licença de trabalho ${ }^{67}$ na rua.

65 Abrigo. Um tipo de centro de atendimento para as pessoas moradoras de rua e, recentemente, aquelas que chegam como desplazados.

66 Ciro Guerra nasceu em Rio de Oro no estado de César em 1981. O estado está localizado a 847Km ao nordeste de Bogotá.

67 No ano de 2004, foi aprovado o decreto (decreto distrital 98 de 2004) que regula as vendas na rua. Foi criado um sistema de cadastramento que controla quem vende, o tipo de mercadoria e o número de pessoas que podem trabalhar desta forma. A permissão é emitida em qualquer estação de polícia da cidade, após o pedido 
Este dia tem algo de particular, o homem que cotidianamente caminha pela calçada, é observado por um desenhista - dentre outros que estão na rua oferecendo seus serviços artísticos. Um primeiro plano dos olhos do desenhista e um contra-plano dos traços no papel, deixam ver que não é a primeira vez que o artista observa o homem da cadeira. Alguns traços já compõem seu desenho, parece que ele é completado dia após dia, toda vez que o homem da cadeira passa por esse lugar. Como se o trabalho de fixar a imagem do outro fosse um que requeresse paciência e dedicação. Depois do incidente com a polícia, o homem da cadeira é obrigado a voltar ao lar, lá encontra Mañe em pé, utilizando uma nova perna artificial fabricada pelo homem. Sem pronunciar uma palavra lhe oferece pão e chá.

Os dois, sentados na grama fora da barraca, comem e bebem em silêncio. Mañe faz gestos de desagrado e desassossego, olha para o fora do campo, como se estivesse reconhecendo o lugar ou procurando um motivo para conversar. Vê uma caixa preta fechada com chave e tenta pegá-la, mas o homem a agarra primeiro, segura-a no regaço e fixa os olhos em Mañe, que lhe pergunta seu nome. Pergunta simples e cotidiana que é respondida com outra: "Como você ficou coxo?". Mañe, incomodado, fica um tempo em silêncio, comenta sobre o péssimo gosto do chá e faz outra pergunta: "Porque me ajudou? Hein?" E, sem dar tempo para a resposta, continua: "você tem sido o único a me ajudar, irmão. Neste país filho da puta, ninguém recebe ajuda de ninguém, irmão". A resposta, o silêncio e o gesto de olhar.

Esta cena põe em evidência a dificuldade do olhar, do fato e do ato. O gesto é o de olhar, a expressão é escondida e não se pode saber qual a intenção ou o objeto do olhar: o homem da cadeira estará, de fato, olhando? É possível ter certeza deste olhar? E mais, sem os olhos descobertos é possível falar sobre o olhar de alguém? Uma imagem que põe em evidência a centralidade do olhar para a construção da narrativa fílmica e instiga a reflexão sobre a relação entre visão e conhecimento. Segundo Novaes (2009), esta relação é fundamental no ocidente e está embasada no princípio da distância para a observação e com isto, para o conhecimento. A autora discute esta relação e a posição paradoxal das imagens no interior das ciências sociais. O que me interessa ressaltar aqui é a afirmação do conhecimento a partir da observação, que é própria não só às ciências sociais, mas à medicina e a botânica,

formal do trabalhador. Disponível em: http://www.alcaldiabogota.gov.co/sisjur/normas/Norma1.jsp?i=14179. Acessado em 08/2011. 
entre outras disciplinas, e a ideia de que a distância se traduz no controle do observado. $\mathrm{O}$ homem ao cobrir os olhos, mostra e oculta os olhos, mas, sobretudo, diz que não quer conhecer, não vai observar, o que vai fazer é criar a maior distância possível entre ele, as pessoas e a cidade. Não se trata de uma vontade de conhecimento, e sim de uma vontade de não conhecimento.

Se bem que a vontade do personagem é de esquecer e de apagar seus traços; a construção fílmica dele se apoia em certos objetos que prendem nossa atenção: a caixa preta que foi introduzida na cena anterior, a planta e a cadeira mostradas na primeira cena. Estes dois últimos objetos identificam o homem, enquanto o primeiro é motivo de mistério, sua presença ou conteúdo não são comentados, mas a interação com o objeto o coloca em um espaço diferente dos outros objetos. É como se a negação do olhar e o chamado a olhar fossem atos que, no filme, acontecem simultaneamente. Em outras palavras, seria o distanciamento e a aproximação realizados pela imagem fílmica, que traz ao agora (de quem observa) o passado e o distante (o observado), mas que também ao copiar, desloca (Taussig, 2005). O objeto escondido, que não pode ser nomeado e que poderia ter sido um motivo para Mañe começar uma conversa, é a introdução para uma frase quase banal e cotidiana: "neste país filho da puta, ninguém recebe ajuda de ninguém". A normalidade da frase mostra um certo estranhamento para a forma de se relacionar das personagens, o vínculo de amizade e solidariedade, mas também silêncio e distanciamento.

Mañe desce a rua na cadeira do homem e, desafiador, grita aos jovens, que desconcertados, não reagem. Na calçada da séptima os dois concordam em se encontrar na estátua da Pola ${ }^{68}$ toda vez que Mañe precisar subir por aquela rua perigosa que o leva até em casa. É uma promessa de ajuda sem um motivo claro que a justifique. Durante o trajeto, a conversa continua, planos fechados e amplos, enfatizam a posição de cada um e os inserem na cidade. A partir de então, graças à curiosidade de Mañe, conhecemos o homem que

68 Policarpa Salavarrieta, heroína da independência colombiana, símbolo da luta pela liberdade e do heroísmo feminino. É o local onde Mañe ensinará, em uma cena posterior, o homem a ler e escrever. Sua repetição como cenário ao longo do filme, não é casual. Ela foi ativa na "revolução dos comuneros", uma revolução armada contra o governo espanhol pela redução dos impostos, entre outras coisas. A Pola foi uma mulher fundamental na condução de informações dos patriotas, pois lhes informava sobre ações militares e servia de comunicadora das noticias entre eles. Foi fuzilada em Bogotá no dia 14 de novembro de 1817. (ver Castro..., ) 
carregava pessoas de um lado para outro do rio César ${ }^{69}$ para que não se molhassem os pés. Trabalho que, de certo modo, hoje faz nas ruas de Bogotá, para ganhar algum dinheiro e para que os pedestres não se cansem no andar cotidiano. Distraído com a insistência interrogativa de Mañe, o homem se choca contra um policial. O mesmo que antes lhe exigiu a permissão para trabalhar. A música rápida e a câmera movimentada com agitação acompanham a carreira do homem para salvar a cadeira, mas uma rua sem saida facilita o trabalho dos policiais que, finalmente, confiscam o objeto.

Sem a cadeira, o homem caminha pela cidade sem rumo, uma música triste acompanha o trajeto à barraca. O homem dorme, ouvimos fora de campo um radiotransmissor. $O$ homem, assustado levanta-se do colchão olha fixamente para a fonte do som, depois de um curto silêncio vemos um braço estendido que entrega uma folha papel sulfite. Um plano subjetivo serve para entender que se tratava da visita de um policial - o som do radiotransmissor identifica este personagem - que subiu até a colina para lhe devolver a cadeira. De volta ao trabalho, o homem leva pessoas de um lugar para outro e Mañe faz figuras de papel. Estes se encontram e Mañe lê o papel que o homem recebeu na noite anterior: é uma permissão para trabalhar ${ }^{70}$, tudo graças ao uso dos segredos de corrupção que Mañe conhece sobre o Sargento Osvaldo Jaimes. Em seguida, Mañe bebe o chá e tem uma alucinação.

A imagem se desfoca. A voz do homem que quer tranquilizá-lo sofre uma deformação, é metálica e com eco. Mañe coloca os óculos, deixa cair a cabeça para trás e vira rapidamente os olhos de um lado para o outro. A voz repete "você vai ver", as nuvens cinza tornam-se ameaçadoras. Um close- up de um olho dilatado ocupa o quadro. Este plano se sobrepõe ao copo que Mañe segura na mão. Inicia-se um travelling em plongée $e^{71}$ pelo corpo de Mañe, a cabeça, o chão. De repente, o som de trovões e flashes de luz como raios. O último deles

69 É um rio ao norte da Colômbia, separa a Sierra Nevada de Santa Marta da cordilheira dos Andes. Nasce na alta Guajira e desemboca no rio Magdalena. A cidade mais importante próxima ao rio é Valledupar, capital do estado de César, o estado natal de Ciro Guerra.

70 A permissão indica que a pessoa pode trabalhar sempre que a atividade não esteja contra a lei. Mañe comenta o texto dizendo "la ley del rebusque". Rebuscar é buscar minuciosamente, uma atividade que se tornou cotidiana diante de uma situação econômica difícil, quando as pessoas inventam os mais diversos tipos de atividades econômicas na rua, venda de todo tipo de coisas, comidas, exposição de saberes artísticos como artesanato, malabares, música, desenho, canto e oferecimento de serviços. Esta atividade de sobrevivência tem levado algumas pessoas a tomarem atitudes extremas, de roubo e assalto de formas não criminosas como a enganação. Uma forma de viver na rua que hoje colore as cidades grandes, lhes confere um ritmo de carnaval (música, acrobacias) e de violência (engano ao pedestre distraído).

71 Plongée é um plano no eixo vertical no qual a câmera está acima do objeto. 
transforma o chão de tijolo em uma rua de asfalto, quebrada e molhada por uma forte chuva. A câmera agora está muito perto do chão, vemos projéteis jogados, primeiro dois, o som da chuva mistura-se ao som do que parece ser uma metralhadora sendo acionada. O travelling da câmera parece contar vagarosamente os projéteis: três, quatro, cinco, seis, sete, oito!, nove!, dez!. Uma arma... um braço sem vida e com traços de sangue, uma navalha e o asfalto molhado e vazio. Um novo tipo de som e um bastão no chão, a câmera continua o movimento e levantando o ângulo um pouco enquadra Mañe caminhando normalmente, os braços estendidos e o rosto voltado para o céu, recebendo água, os olhos fechados e uma expressão de sofrimento. As nuvens cobrem rapidamente o céu e um raio de sol aparece e ilumina a cena até superexpor o plano. Mañe volta a si, já é tarde, o homem não está mais ao seu lado, e ele procura assustado vestígios de sua presença, grita: "senhor! senhor!”.

Mañe acorda, encontra o homem e conta animadamente sobre os efeitos do chá, não descreve as imagens e sim a sensação de prazer experimentada, em contraste com o tipo de imagens vistas. Resta a dúvida, foi uma cena de alucinação (irreal) ou foi um flashback (lembrança), especialmente se queremos versar sobre as maneiras de se contar uma experiência passada. Um flashback, segundo Turim (1989), ocorre quando uma "junção é forjada entre o presente e o passado e dois conceitos estão implicados nesta junção: memória e história" (ibid., p. 1), é uma representação cinematográfica da memória subjetiva inserida na história. Uma alucinação diz respeito da fantasia, a ausência de razão ou enfim, a irrealidade daquilo que está acontecendo, mas também pode ser vista como uma articulação original de elementos díspares que expressa.

Sobre a alucinação e a fantasia, Michael Taussig (1986), que realizou seu trabalho de campo no Putumayo colombiano entre 1969 e 1985, tratou de questões como a ficção do real, o papel do mito e da magia na violência colonial e sua cura, a maneira como a cura pode mobilizar o terror a fim de subvertê-lo não por meio de catarses, mas por uma forma que faça derrubar o poder na sua própria desordem. Taussig levou adiante uma proposta de pesquisa sobre o assassinato e a tortura na qual o que importa não é a verdade, mas o ser social da verdade. Não importa se os fatos são reais, mas se a política de representação e interpretação o é. É também uma forma de entender o terror não como algo que destrói, mas como algo que cria realidade. Um pensamento que reflexiona sobre o conflito armado interno em termos 
diferentes que os das relações estruturais entre os grupos da sociedade, questões políticas ou econômicas que marcam o fenômeno, e nos permite, assim, atentar para outras coisas, como as narrações e as alucinações, formas subjetivas e não-oficiais de entender e contar essa realidade.

O autor, no livro de 1986, "Shamanism, colonialism and the wild man. A study in terror and healing" reflete sobre a violência causada pela extração de borracha e expõe como a violência é elaborada em narrações de diferentes tipos. $\mathrm{O}$ antropólogo se interessa nas elaborações instigadas pelo yagé, porque são narrativas que além de elaborar o terror, propiciam uma cura. Trata-se de uma elaboração cultural do medo em narrativas que incluem verdade e fantasia, rumores, mistérios, discursos oficiais e a própria biografia. Estas narrativas criam uma realidade incerta na qual a verdade e a ilusão são forças sociais (Taussig, 1986, p.121) que teriam o poder de dar alívio ao sofrimento ou à angústia. Mas também poderiam ser narrativas como as que elabora a arte, cuja função é menos dar alívio (cura) do que explorar formas de expressar o terror.

No mesmo campo de interesse, Alejandro Castillejo (2005, 2006 e 2009) discute a relação entre memória, violência e a elaboração da lembrança nos contextos do processo das mesas de reconciliação pós-apartheid na África do Sul e no processo de verdade e reconciliação na Colômbia. A imagem, para o pesquisador, estrutura um mundo imaginado dentro de uma lógica particular, da mesma forma como as narrativas sobre a guerra articulam e condensam múltiplos elementos que oferecem formas de pensar e falar sobre ela. Castillejo se interessa pelas formas de encenar o corpo do inimigo, nas formas de identificá-lo e fazer dele, do seu corpo e da sua pessoa, a representação do disforme, do feio e do grotesco. É este corpo que o pesquisador vê quando estuda a produção audiovisual como evidência do crime (Castillejo, 2005). Nessa medida, ele encontra uma estética da morte, uma fascinação pelos corpos sem vida que a câmera percorre em detalhe, em primeiros planos e se fixando nas feridas e estabelecendo associações entre o corpo e os objetos da morte (armas). O problema, então, é a produção de uma verdade, a construção daquilo que é permitido observar/interpretar. De fato, o filme não se insere no jogo da produção de evidências (no sentido jurídico), o que seria dar ao filme uma importância que ele em si mesmo não tem, porém, ele é um objeto que circula e se relaciona com outras imagens sejam elas do campo do cinema ou não. 
A imagem cinematográfica copia o original sem se limitar a este. Ou seja, o poder da imagem não se encontra em sua veracidade (em ser um fato que possa ser conferido na realidade), mas, na sua capacidade de pôr em contato o corpo de quem percebe com o daquele que é percebido (Taussig, 1993). Uma força mimética se relaciona com o fisionômico, a força tátil do olhar que leva o espectador à tela e lhe oferece uma experiência fora de si mesmo. Neste processo, a tela imprime imagens surpreendentes do outro na sua memória, obrigando-o a ver de novo, a refletir e narrar o visto. Neste sentido, Piault (2000) define a tela como um espaço de intersubjetividade, cuja profundidade temporal transforma os sentidos das imagens pela construção progressiva (imagem em movimento). Da tela emerge um lugar de memória social, de inscrição e expressão e de questionamento das certezas ${ }^{72}$.

"Não grite! Tranquilo, estou aqui" Responde o homem. Os dois sobem uma ruela, Mañe caminha muito feliz e agradece ao homem por ter lhe dado o chá; o homem atrás dele sorri ao ouvir os comentários. De repente, sai das sombras um homem que mancando com uma garrafa de cerveja na mão direita se aproxima dos protagonistas e grita. Reconhecemos o Sargento Jaimes, que levanta o braço direito em atitude violenta, ameaçando bater em Mañe. O homem rapidamente se aproxima, neste momento o sargento cai, alguma coisa deteve sua ação. O sargento sofre do coração, um ataque o derrubou. O homem tem a intenção de ajudar o desconhecido, mas Mañe o impede e começa a dizer todo tipo de maldições contra o Sargento. É um momento de libertação, de vingança agora que a figura opressora está enfraquecida. O homem não obedece e com o corpo do Sargento nos braços sai correndo. Mañe chega em casa e encontra a irmã que muito agradecida pela ajuda oferece abraços, sorrisos, bênçãos e um empréstimo para pagar o aluguel.

No dia seguinte, amigos e aguardiente comemoram o socorro que Mañe (o amigo de Mañe) deu ao Sargento. Doña Marelvis usa roupas bonitas, está sorridente. A casa está iluminada pelo sol - é o único momento do filme em que a luz do dia ilumina esta casa, hoje o Sargento voltará ao lar e quer agradecer a ajuda que o homem lhe ofereceu nesse momento de crise. Longe da celebração, o homem caminha pela cidade, os olhos atentos de um desenhista capturam sua imagem. Seu retrato está sendo completado. Na estátua da Pola,

72 Há imagens na tela que funcionam como o motor que obriga o espectador a "abrir os olhos". O filme de Alejandro Amenábar Abre los ojos (1997) é um bom exemplo disto: no início do filme uma voz repete "abre los ojos, abre los ojos" com a tela em preto, o que prepara o espectador para um despertar violento dentro da imagem. Ao longo do filme se repete este momento, cada vez acordando em realidades diferentes. 
Mañe aguarda impaciente, o homem chega e lhe entrega um caderno e um lápis, é a primeira aula de escrita do homem. Na cena anterior, ele tinha se declarado analfabeto, tudo que o pai lhe havia ensinado foi o que escreveu no cartaz. Planos de letras, indicações sobre como escrever, como utilizar um lápis são acompanhadas por um trecho da sonata para piano Andantino do compositor Franz Schubert, música que comenta a relação das personagens em alguns momentos.

O objeto do cinema está em perpétua transformação, “o objeto representado no cinema é uma representação em devir. Todo objeto, toda paisagem, por mais que sejam estáticos se encontram, pelo simples fato de serem filmados, inscritos na duração e entregues à transformação" (Aumont, 1983, p.64, tradução minha) ${ }^{73}$. A imagem materializa uma proposição, é um fragmento e um meio para pensar sobre o mundo do possível. Mundo cujo sentido é construído pela montagem. Um duplo processo de isolar, de desterritorializar e recompor situação que nos permite "mergulhar" nelas. Este movimento revela níveis de experiência ao mesmo tempo em que é um ato criativo que desafia o olhar, é um redescobrimento, uma restauração do que é reprimido (Nieland, 2001). Imagem em construção que, pensando na relação entre as personagens, suas ações, e os lugares que ocupam no filme de Ciro Guerra, cria as condições para narrar, para articular o que dificilmente é articulável, possibilita pensarmos o cinema como um lugar onde se podem gestar subversões do terror ${ }^{74}$. A característica cinemática do cinema, ou seja, a imagem em movimento faz antes pensar do que oferece novas verdades ou versões definitivas. É uma forma específica de apreender o real. Nesta linha de pensamento, Juan C. Arias (2010) propõe pensar a dimensão política do cinema colombiano:

[...] muitos realizadores colombianos afirmam que nos seus filmes, de uma ou outra maneira, têm a oportunidade de aprofundar nos problemas que já nos parecem cotidianos e mostrar uma cara da realidade que poderia permanecer

73 "Le représenté au cinéma est un représenté em devenir. Tout objet, tout paysage, aussi statique soit-il, se trouve, par le simple fair d'être filmé, inscrit dans la durée et offert à la transformation".

74 Subversão não necessariamente significa outra versão, pode também ser uma versão que destabiliza a ordem, que arrebata histórias ao esquecimento. O filme La noche de los lápices (1986) dirigido por Héctor Oliveira, que narra o sequestro, tortura e desaparecimento de seis jovens durante a ditadura argentina, é visto por Jimeno (2008) como um exemplo de uso das estratégias narrativas da ficção para "fazer os desaparecidos reaparecerem" (ibid., p. 184) levar o sofrimento íntimo para o público, tirar o testemunho do campo jurídico para torná-lo memória. Um procedimento que impede esquecer a "maior tragédia na nossa história [argentina], e a mais selvagem" (CONADEP, 1984, p. 8) 
velada pelos relatos de outras mídias como a televisão e a imprensa escrita. O cinema se mostra, desta maneira, como a possibilidade de construir outra duração no olhar diante da realidade do país; como a possibilidade de se deter diante de certos fatos ou fenômenos que ignoramos diariamente graças à velocidade das mídias mais tradicionais (ibid., p.136. Grifos meus).

Arias compreende o político do cinema não como a representação de fatos políticos, mas como a capacidade do cinema de configurar novas experiências, sensibilidades e ritmos. Uma posição que parte da avaliação de dois autores: Deleuze e Rancière. O primeiro defende a característica não narrativa da imagem e o segundo, o poder histórico da imagem. Segundo a leitura de Arias de Deleuze, a passagem da imagem-movimento à imagem-tempo é a passagem das imagens como coisas em si mesmas à anulação do dramático. Ou seja, na imagem-movimento não há oposição entre o movimento como fenômeno real e a representação do movimento, já na imagem-tempo se privilegia a duração, a observação e a contemplação em oposição à ação. O caráter político do cinema para Deleuze não está no "registro da materialidade do movimento e do tempo, mas na capacidade de fazer visível a imaterialidade, a invisibilidade do movimento e do tempo além da sua organicidade" (ibid., p. 87). O cinema "cria um novo campo do visível, outro âmbito de percepção" (ibid., p. 94).

Para Arias, a posição de Deleuze é importante porque libera a imagem da representação, porém a partir da leitura de Rancière, Arias entende que o "próprio do cinema é, então, a convivência entre o narrativo e o não narrativo; uma dinâmica de permanente contrariedade entre a fábula e o que Deleuze designou como situações óticas puras" (ibid., p. 109). Segundo Arias, para Rancière a arte não existe sem um "regime de percepção e de pensamento que faça possível distinguir suas formas como formas comuns. Não há arte sem um regime de identificação da arte em si mesma" (Arias, 2010 p.100) As imagens são pensadas a partir dos usos a que servem e os efeitos que estas têm nos indivíduos e na coletividade. $\mathrm{O}$ particular do cinema é para o filósofo a construção de uma vida histórica.

A proposta de Arias para pensar o cinema colombiano é, então, observar a sua capacidade de construir um discurso alternativo sobre o país. Seguindo a ideia do realizador de cinema Víctor Gaviria, o desafio do cinema colombiano seria "construir o real como narração": [...] "[o] cinema [...] desvela a realidade como narração, faz visível além das anedotas que mostra" (ibid., p.142) ou, para pensar nos termos de Deleuze, ele constrói uma 
“imagem-nação e não uma imagem $d a$ nação através de suas imagens e histórias"75 (ibid., p. 141, grifo no original).

Finalmente, Mañe pega o caderno e, muito orgulhoso do aluno, lê seu nome escrito. Repara em um erro, "não é Maña é Mañe” e coloca sua mão na mão do homem e escreve o E encima do A. Depois da primeira aula, os dois caminham lado a lado pelas ruas do bairro de Mañe. Um plano do Sargento que olha pela janela e faz um gesto de surpresa. Mañe, na porta, explica que foram até lá porque o Sargento quer lhe agradecer por tê-lo levado ao hospital na noite em que sofreu o ataque. O homem aborrecido vira as costas e sai rápido do lugar, Mañe assustado corre atrás dele, pois esta visita poderia ser uma grande ajuda para negociar a dívida que tem com os donos da casa. Nessa discussão, Doña Marelvis abre a porta agitada, gritando, pedindo ajuda, o Sargento teve outro ataque, está no chão "como morto", diz ela. O homem vira as costas e sai caminhando, Mañe tenta deter o homem e tira da cadeira a sombrinha. O sol aparece, o quadro agora superexposto, concentra a luz do sol que se transforma em uma ameaça. O homem cobre com as mãos a cabeça e, enfraquecido, cai no chão.

O homem no chão e um sentimento de culpa fazem com que Mañe não ouça os gritos de ajuda de Doña Marelvis e escolha cuidar do amigo. Agora no hospital, vemos planos de sombras de cabeças: a de Mañe preocupado que leva as mãos até a boca, e a do médico que explica um raio $X$ da cabeça do homem da cadeira. No final, a sombra da cabeça de Mañe mostra que ele olha para baixo. Corte. Um cartaz com o nome do Sargento anuncia a notícia da sua morte e do velório. Mañe observa as letras e encontra Doña Marelvis que sai do escuro, vestida de preto, chorando, a casa escura acompanha sua dor. Mañe se desculpa, tenta abraçar a mulher, mas ela o detém com um olhar de reprovação. Comenta que a morte do irmão foi imediata, "é como se tivesse visto alguma coisa que o aterrorizou e... morreu no instante”. Nenhuma ajuda teria sido útil, o Sargento já estava morto quando a irmã foi

75 Posição diferente daquela que vê o cinema como reprodução da realidade (Kracauer). Segundo Osório (2010), um dos grandes expoentes desta posição, os filmes sobre o conflito não são os únicos produzidos na Colômbia, mas são os mais publicizados e tido como exposições eloquentes da identidade nacional. É claro que existe uma profunda relação entre a realidade nacional e o tipo de cinema que se produz, contudo, basear a análise neste argumento reduz o cinema à representação da verdade sem mais pretensões, também falha na compreensão do conflito, sua história, multidimensionalidade e complexidade, assim como limita a compreensão das estratégias de construção da identidade, encenação de papeis sociais, agência de novos sujeitos políticos e respostas criativas às situações e constrangimentos. 
procurar ajuda. Agora que nada pode ser feito, ela pede para Mañe acompanhá-la no velório. Mañe aceita, mas, recebe uma ligação: o homem fugiu do hospital. De novo, ele abandona Doña Marelvis e vai cuidar do amigo.

Com dificuldade sobe até a colina onde o homem ergueu a barraca de plástico. Ali, repousa o homem enfraquecido. Mañe ataca-o com perguntas, faz o chá e obriga o homem a bebê-lo. O questionamento continua, Mañe comenta "sobre o projétil”. O homem, com desprezo, pergunta pelo Sargento ao que Mañe, surpreendido, responde que ele morreu, porque sofria do coração. "Aqui todos sofremos do coração”, responde o homem. Um plano fechado sobre o rosto do homem enquadra a narração sobre a questão "do projétil". Ele conta que foi justiçado, mas aguentou, alguns indígenas o levaram da selva para a montanha e lá cuidaram dele. Uma vez recuperado o homem foi para Bogotá com a bala na cabeça "pra não esquecer". "Porque você veio parar neste buraco ${ }^{76}$ ?", pergunta Mañe ao homem desesperado, que responde que a única coisa importante é que ele está lá e nada mais. Querendo saber quem seria responsável por tal ato no passado, Mañe é culpado pelo sofrimento presente do homem. Um zoom out acompanhado pela sonata Andantino de F. Schubert abandona ali estes dois homens. O movimento sobrepõe à barraca do homem a lápide do Sargento Osvaldo Jaimes. Uma lápide feia, desajeitada, com o nome do morto escrito a mão, sem flores, sem epitáfio. O zoom out continua e enquadra estes dois homens olhando para o lugar onde repousa o morto.

A câmera acompanha o caminhar das duas personagens com um travelling. A câmera posicionada atrás dos homens enquadra suas costas e as fileiras de lápides nos dois lados. É um tipo de composição que confere relevo à voz. A conversa se desenvolve sobre a morte; assunto e lugar: "Isso da morte é uma coisa bem filha da puta para quem não a conhece, para os que ficam. Os mortos, rindo no inferno", afirma o homem com um certo desinteresse no assunto. Mañe sempre muito sério responde: "Eu conheço bem a morte, irmão. Neste país para ser rico o que se deve fazer é criar um cemitério privado, freguês é o que não falta! Como meu pai, como minha mãe. [Eles] os esquartejaram e os penduraram depois, lá em frente de casa, irmão. [...] primeiro nos disseram que foram os guerrilheiros, depois que

76 No filme, Mañe utiliza a palavra moridero que segundo a RAE (Real Academia Española) é "lugar que se torna em um espaço para morrer ou lugar destinado para tal". [Disponível em http://buscon.rae.es/draeI/SrvltConsulta?TIPO BUS=3\&LEMA=moridero Acessado em 05/2012] Na Colômbia utilizamos a palavra para descrever um lugar onde nada acontece, vazio, feio e sujo; não é apenas um lugar onde se morre, pois pode ser o lugar em que se mora, no qual pessoas chegam e de onde as pessoas saem, mas cujas características não permitem uma sensação de vida, como se a vida estivesse estagnada. 
foram os paramilitares, depois que foram os narcotraficantes, depois que foi... o exército! Ao final a única coisa que eu sei é que estão mortos. Como eu”.

Imagens, sons e depoimentos da violência não são um mistério para ninguém. Jornais, noticiários na televisão e rumores constroem nossa geografia do perigo (ruas escuras, vazias, lugares de venda de drogas e prostituição, centros históricos e bairros nas periferias das grandes cidades) e os estereótipos do sujeito perigoso (o ladrão, o assaltante, o solitário e sujo, o hábil e rude). O cinema faz destas imagens, estética e espetáculo. Imagens que de uma ou outra maneira agem no processo de configurar nosso tempo, nossa relação com os espaços e as pessoas que pertencem ao universo da violência. A ordem social se define em torno da desigualdade e seus contornos são definidos pelos seus diversos vínculos com a mídia (Hamburger, 2007). Assim, no caso do Brasil, por exemplo, favelas se tornam problemas, e o cinema, a partir destes espaços, define o "perfil sociológico das preocupações", faz o "inventário das questões sociais" e os tematiza como "caminhos sem saída" (Leite, 2000). Porém, "a raiz do problema não está nos filmes: está nas condições sociais e políticas que determinaram e têm determinado o espaço de intervenção para trabalhos dessa natureza, que enfrentam os desafios e limites próprios a uma produção cinematográfica que, empenhada na crítica se recusa a assumir uma concepção instrumentalista da cultura popular ou não" (Xavier, 2007 p. 193). Em outras palavras, trata-se de "estilos cognitivos que determinam os modos de se organizar em sociedade" (Samain, 1998, p. 142) que, como já disse, orientam qual é a função da arte, quais são os temas e as formas de encená-los em um complexo de relações que permitem versões e subversões do tema.

Em cenas anteriores se fez referência explícita ao passado de Mañe, que podem ser pensadas como preâmbulo do relato que o personagem acabou de pronunciar. As dimensões do horror do ato não diferem muito do que é publicado em jornais e revistas, ou mostrado nos noticiários na televisão, especialmente a partir de 2005, ano em que se inaugura o processo de Justiça e Paz $^{77}$ (lei 975 de 2005) do qual a Colômbia é cenário. Esta é uma lei que oferece alternativas penais a membros de grupos armados à margem da lei, para lhes oferecer uma via de se reincorporar à vida civil. Além disso, é uma lei que estabelece a necessidade de criar

77 Ley 975 de 2005 (julio 25) pela qual se ditam as disposições para a reincorporação de membros de grupos armados organizados à margem da lei, que contribuam de maneira efetiva à consecução da paz nacional e se ditam as disposições para os acordos humanitários. Congreso de Colombia 
estratégias de reparação às vitimas ${ }^{78}$ destes grupos armados que participam da lei e afinar as estratégias do governo para lidar com as elas no nível jurídico, social e econômico. A resposta a esta necessidade foi promulgada em 2011 pelo presidente Juan Manuel Santos, que definiu a lei de vítimas e restituição de terras (lei 1448 de 2011) ${ }^{79}$. É um processo que depende inteiramente da fala: de depoimentos, testemunhos, versões sobre as diversas agressões, confirmações ou negações destas versões ou de partes delas. A lei possibilita que a vítima, que se reconhece como tal, se aproxime do Estado. Isto ocorre com o cadastro da vítima e do encontro destas em locais ou "salas" onde lhes é concedida a oportunidade de reconhecer a pessoa que denunciaram como o "agressor" ${ }^{\prime 2}$. A partir disso, segue-se um processo de investigação que irá confirmar ou negar o que foi dito na sala e decidirá sobre a pena do agressor e a reparação à vítima. Em síntese, este seria o procedimento legal. No entanto, o que me interessa chamar atenção é para a multiplicação de testemunhos da violência que foi gerada com a lei.

Um dos fatores que propiciou o que chamo de "multiplicação de testemunhos da violência" foi uma conjunção entre a obrigação de divulgar os direitos das vítimas e o clamor da sociedade por conhecer sua história e sua necessidade de lidar com a violência, particularmente a pressão exercida pelas vitimas e numerosos ativistas dos direitos humanos. Um dos decretos (4760 de 2005) diz que programas de promoção e informação serão desenhados, que organizações de vítimas serão envolvidas e que a Comissão Nacional de

78 Para permanecer dentro do discurso da lei e fazer explicito o que quero dizer com "vítima", apresento aqui uma tradução de algumas linhas do artigo 5, capítulo 1 "princípios e definições", "[...] entende-se por vítima a pessoa que individual ou coletivamente tenha sofrido diretamente prejuízo como lesões transitórias ou permanentes que resultem em qualquer tipo de deficiência física, psíquica e/ou sensorial, sofrimento emocional, perda financeira ou deterioramento de seus direitos fundamentais. Os prejuízos deverão ser consequência de ações que tenham transgredido a legislação penal, realizadas por grupos armados à margem da lei. Também se entenderá por vítima o cônjuge, companheiro ou companheira permanente e parente em primeiro grau de consanguinidade, primeiro civil da vítima, quando esta fosse morta ou desaparecida [...]" (Ley 975 de 2005).

79 A ley de víctimas y restitución de tierras (ley1448 de 2011) Pela qual se ditam as medidas de atenção, assistência e reparação integral às vítimas do conflito armado interno e se ditam outras disposições. É uma política que pretende reparar integralmente as vítimas do conflito armado interno, fortalecer a estrutura judiciária e administrativa para promover a paz e a reconciliação nacional. A lei define quem é uma vítima, as formas de reparação e dá especial atenção à questão da restituição das terras. Disponível em: http://www.leydevictimas.gov.co/, Acessado em 05/2012.

80 Estes encontros são momentos de verdade. Vítimas denunciam, exigem informações sobre o destino de seus parentes; e, por sua vez, agressores (paramilitares) escutam, aceitam a culpabilidade e fornecem algumas informações a respeito dos parentes. As salas são espaços de encontros virtuais, vítimas e agressor interagem graças a um sistema de comunicação pela internet. As vítimas estão sentadas frente a uma grande tela onde aparece o agressor. Todas as denúncias são públicas, assim como as respostas. Hollman Morris e Juan Lozano lançaram em 2011 o documentário Impunity, que explica o funcionamento da lei e faz um balanço do processo. Existe uma versão de 30min no youtube, disponível em: http://www.youtube.com/watch? $\mathrm{v}=$ CNKISxzkdQA. Acessado em 05/2012. 
Televisão prestará seus serviços para o bom andamento destas campanhas. Outro dos fatores, atrelado à questão dos direitos das vítimas, foi a ideia de que a difusão dos testemunhos das vítimas no espaço público por meio das diversas mídias, levaria ao reconhecimento por parte da sociedade destas pessoas e sua consequente inclusão social. São criadas múltiplas instâncias governamentais e não governamentais ${ }^{81}$ para vigiar o funcionamento de tal processo e circulam massivamente versões escritas, radiofônicas e audiovisuais produzidas com o fim de difundir os testemunhos das vítimas. Assim, surgem em todos os formatos testemunhos de vítimas: a série de documentários "Nunca Más" ${ }^{22}$, entrevistas de rádio "las víctimas cuentan", algumas cartilhas, entre elas a publicada pela CNRR e outra pela Procuraduría General de la Nación $(\mathrm{PGN})^{83}$, vários livros publicados recentemente a partir das pesquisas do grupo de "Memoria histórica" 84 da CNRR onde são compilados os diferentes depoimentos e questões para cada caso e, um programa de televisão, "Tiempo de la verdad" produzido pela PGN e realizado por uma produtora privada, no ano de 2008. Ou seja, na Colômbia assistimos a um processo de proliferação da verdade, de discursos sobre a violência, em um país onde o silêncio é estratégico, a pressão se dirige à produção de testemunhos.

La sombra del caminante foi filmado no ano de 2002 e lançado no ano de 2004, ou seja, é uma obra que não participa desta produção de verdades ou das discussões sobre as vítimas do conflito e, tampouco se quer uma obra que discute estes assuntos. Contudo, a circulação do filme no espaço público faz com que vínculos e comparações possam ser realizados. É um filme que encena a vítima em um momento em que esta está sendo discutida e representada massivamente, cujas palavras estão sendo exigidas e circuladas nas distintas mídias, e, quando

81 Comisión Nacional de Reparación y Reconciliación (CNRR), disponível em: www.cnrrorg.co., Procuraduria General de la Nación (PGN), disponível em: www.procuraduria.gov.co, Fundación social, disponível em: www.fundacion-social.com.co, Centro Internacional para la Justicia transcicional (ICTJ), disponível em: www.ictj.org, Verdad Abierta, disponível em: www.verdadabierta.com; entre outros. Estes sites são acessados regularmente.

82 É uma série realizada pela Comisión Nacional de Reconciliación y Reparación (CNRR), órgão criado pela lei 975 com o objetivo mediar o processo de negociação. Os capítulos estão disponíveis no canal da CNRRColômbia, no site de vídeos Youtube: http://www.youtube.com/user/CNRRColombia. Acessado em 05/2012.

83 A primeira, sob o titulo "Soy una víctima? Tengo derechos", foi publicada em 2007 pela CNRR, explica e identifica as vítimas. A segunda, publicada no mesmo ano com o nome "primero las víctimas. Criterios para la reparación integral víctimas individuales y grupos étnicos" pela PGN (órgão do governo que vigia a função do Estado, o homologo no Brasil é o Ministério Publico Federal (MPF)).

84 Memoria Historica (MH) é um grupo de pesquisa da CNRR que tem o objetivo de "elaborar e divulgar uma narrativa sobre o conflito armado na Colômbia". Quienes somos. Qué es Memoria histórica. http://www.memoriahistorica-cnrr.org.co/s-quienes/sub-quees/. Acessado em 05/2012.

85 Este programa de televisão foi objeto de pesquisa no trabalho de conclusão do curso de graduação. (cf. Gómez, 2008). 
o que está em jogo é a construção de uma verdade e de uma narração da história de violência na Colômbia. Apesar de não ser um filme dentro desta lógica de produção de imagens, pelo contexto em que circula, pode ser visto e construído neste trabalho como um contraponto. Fazendo jogos de palavras, o filme é o contraplano ou até o fora-do-campo. O que não é visto, mas que completa, dá sentido a imagem e mostra suas potencialidades de significação. É um filme que se coloca diante de uma situação já antiga no país e se relaciona com as formas de narrar tal situação. Porém, é uma obra que para a espectadora-pesquisadora não deixa de se relacionar com o processo, particularmente pelo interesse na experiência da vítima e pela estratégia do filme de dar relevo às coisas cotidianas dessa situação.

A história da cinematografia colombiana ${ }^{86}$ é construída, sobretudo, a partir de críticas de cinema publicadas em jornais e revistas especializadas em cinema. É uma crítica que se preocupa por identificar características de cada filme, estabelecer uma cronologia e estilos. Segundo este grupo de críticos-historiadores existe um grande interesse pelas figuras públicas, lideres políticos, narcotraficantes ou atos famosos. Têm sido produzidos poucos filmes com histórias relacionadas às vitimas da violência política colombiana (Salcedo Silva (1981), Martínez Pardo (1978), Valverde (1978), Álvarez (1988) e Osório (2010)). A partir destas obras traço, superficialmente, o caminho que tem seguido o cinema colombiano sobre violência. Os filmes mais antigos se preocupavam por estabelecer histórias universais. Esta fué mi vereda (1954) de Gonzalo Canal Ramírez e Río de las tumbas (1964) de Julio Luzardo, segundo a crítica que receberam, são filmes iniciais que mostram ataques a povoados e as consequências da violência política no país.

O cinema político que surgiu entre a década de 1960 e 1970 é marcado pela forma documental de denúncia e se interessa pela questão da terra, os campesinos e a pobreza. A diretora e antropóloga Martha Rodríguez e o diretor e fotógrafo Jorge Silva são as personagens mais importantes desta época. Já entre 1980 e 2000, diretores como Carlos Mayolo e Luis Ospina começam a mostrar a violência por meio de metáforas e alegorias - ou seja, o uso de elementos surrealistas e empréstimos do realismo mágico, como no filme Carne de tu carne, (Carlos Mayolo, 1983) onde o ato canibal expressa relações de desejo, violência e dinheiro. Nesta época, o cinema de Rodríguez e Silva continua sendo importante, o que leva ao desenvolvimento do falso documentário e do documentário de ficção, este

86 Não querendo relatar aqui os detalhes da história do cinema colombiano, apresentarei alguns momentos importantes para entender seu desenvolvimento. O objetivo principal é estabelecer um quadro no qual possa ser localizado o filme analisado nesta parte do trabalho. 
último representado por Victor Gaviria, diretor de Rodrigo D. No Futuro e La vendedora de rosas, filmes onde a vítima, sua voz, seu corpo, sua experiência são protagonistas. Alguns filmes mais recentes elaboram aspectos do realismo mágico da obra de Mayolo e Ospina e segue a via intimista de Gaviria, sendo assim, filmes que sugerem outras relações não só com a imagem, mas com seu principal objeto: a violência.

Um filme que vale a pena destacar entre este cinema contemporâneo é La primera noche (2003) de Luis Alberto Restrepo, que conta em detalhe a história de uma família campesina que é destruída pelas opções dos filhos; um escolhe o exército e o outro, graças ao tio, encontra as guerrilhas. Construída por grupos de oposições passado bom/presente ruim, rural/urbano, bem/mal, o filme mostra o trajeto que esta família teve de seguir até chegar a Bogotá depois de um ataque guerrilheiro ao povoado onde moravam. O filme chama a atenção porque mostra o que se tem por mais óbvio do deslocamento forçado: o próprio deslocamento. Da própria casa para a de um vizinho, de um povoado para outro, de um departamento a outro e, finalmente Bogotá. Cidade escura e habitada por seres feios, perigosos, de modos de vida e comportamento estranhos. Um filme importante na cinematografia pelas escolhas estéticas e pela densidade de informações que consegue articular sem fazer do filme uma aula lúdica sobre o deslocamento. La primera noche é uma obra realizada por um diretor com grande experiência em cinema e televisão, que teve um público médio de 100.000 espectadores $^{87}$ e que ainda hoje é considerada uma peça importante sobre o tema do deslocamento forçado na Colômbia ${ }^{88}$.

Os dois filmes mostram o conflito a partir de um ângulo íntimo e tentam transmitir o sentido e as implicações dessa guerra para as personagens. Os dois mostram dimensões do deslocamento forçado na Colômbia, aproximam-se do mundo subjetivo de personagens marginais para elaborar imagens sobre uma situação, que mostra aspectos pouco veiculados pela mídia. No filme de Restrepo, nota-se uma vontade de explicar, de mostrar plano a plano o trajeto, os detalhes dos lugares por onde passam as personagens, a comida, o medo e a reconstrução do evento (em flashbacks que se relacionam pela lógica causa-consequência com

87 Proimágenes em movimiento. Estadísticas de espectadores y taquilla. Disponível em: http://www.proimagenescolombia.com/secciones/fdc/otros_documentos fdc.php?nt=17. Acessado em $05 / 2012$.

88 Como o indica a programação da mostra de cinema "Pongámonos em sus zapatos - Desplazamiento y refugio" (ponhamo-nos no seu lugar - deslocamento e refúgio) realizada pela ACNUR para comemorar o "dia mundial do refugiado" em 6 de julho 6 . Notícia disponível em: http://www.proimagenescolombia.com/page_2011//secciones/pantalla_colombia/breves_plantilla.php? id noticia $=3437$. Acessado em 05/2012. 
as cenas do presente). Já no filme de Guerra, a ênfase está no segredo, naquilo que não é dito, mas está presente de diversas maneiras: nos olhos-óculos do homem, na cadeira, no projétil, na perna-de-pau de Mañe, nas perguntas e nos silêncios.

Taussig (1999) discute a forma em que o segredo público - aquilo que é conhecido, mas que não pode ser articulado - é revelado. Sendo o segredo a essência do poder que mantém viva as instituições públicas e elabora o conhecimento público, este não poderia ser desmascarado sem alterar profundamente todos os níveis da realidade. Portanto, toda tentativa de contar o segredo é uma estratégia que o alimenta e fortalece o poder. A busca do antropólogo é por formas de revelar o segredo que lhe façam justiça, a desfiguração como a forma ideal de revelar e dissimular, de provocar uma perpétua instabilidade ao redor do segredo para liberá-lo. O filme não conta em detalhe, não identifica e não se propõe a ser uma peça de informação utilizada na pesquisa sobre os fatos da violência. O filme desfigura o rosto do personagem para que ele possa se liberar e, finalmente, contar sua história.

Sentados tranquilamente entre tantas tumbas, bebem o chá. O homem afirma que tem inveja dos mortos, "aqui somos bons pra matar, sabe. O fazemos melhor que ninguém. Ser um morto colombiano é um orgulho que custa caro". Mañe, pensando nos efeitos alucinatórios do chá, diz que na sua terra, Caquetá ${ }^{89}$, ele não poderia bebê-lo porque já estaria sob a ameaça de morte. O nome do Estado, Caquetá, inicia uma série de planos subjetivos do homem: ele vê as cruzes das lápides, um som ameaçador e finalmente um plano fechado dos olhos-óculos do homem. Começa uma música triste que os acompanha a um lugar distante nas colinas. Durante o trajeto, Mañe insiste nas perguntas sobre o passado e os motivos do homem, este só responde com evasivas e conta um apelido que tinha: "Mansalva" $"$.

Agora Mañe está sob o efeito do chá. Contente afirma que desde que chegou em Bogotá é a primeira vez que se sente assim. O homem, pergunta pelos motivos da ida à cidade. Mañe, que nunca recusa uma resposta, com o rosto virado para o céu, os olhos fechados, um sorriso na boca e o copo de chá na mão, diz que foi pelo mesmo motivo de todos, ameaças. Se não tivesse feito tal percurso, ele estaria com seus pais. Amaldiçoa os criminosos, e o

89 Estado que está localizado no sudeste do país, a capital é Florencia. O Estado começa nos Andes e termina na selva do amazonas. É um lugar de passagem muito utilizado para ir de uma região à outra.

$90 \mathrm{O}$ apelido do homem significa, sem perigo nenhum, sob segurança. 
homem pergunta se foram eles ${ }^{91}$ os que o deixaram assim, coxo. Sim, foram eles. E, entre o estado de alucinação e indignação começa a contar.

A voz sai com esforço. O corpo balança para frente e para trás. Os olhos sempre fechados e o rosto virado para o céu. Como se ele estivesse vendo ao rememorar. Ele e sua família moravam em uma casinha do lado do Hospital Militar e por isso "nos arruinaram!", diz. O homem surpreso levanta a cabeça e repete com uma voz fraca, interrogativa: “Hospital Militar”. Sim, diz Mañe, em um povoado muito tranquilo, Puerta Nueva ${ }^{92}$. Os olhos ainda fechados se contraem. A lembrança causa dor. Os pais foram acusados de esconder alguém, por isso os mataram. O homem aperta os lábios e continua olhando para o fora do campo em silêncio. Mañe estava escondido e escutava os barulhos, o tiroteio, as casas sendo destruídas, os gritos, o Hospital sendo atacado. De repente, um estrondo e a dor. E depois nada, só as lembranças e eles, os sobreviventes. Enquanto ouve, o homem desvia o olhar e abaixa a cabeça. Mañe bebe a última gota de chá e faz um gesto de prazer.

Uma música os acompanha de volta à casa de Mañe. O homem despede-se para sempre, não mais ajuda, não mais aulas, não mais conversa. Mañe, inocente e com medo de reencontrar a solidão, presenteia o homem com um origami de um pequeno homem com uma cadeira. O desejo de Mañe é que o homem confie nele, mas o homem está irritado. $O$ presente e a confissão de amizade são fúteis e só conseguem o enraivecer. A discussão é finalizada com uma imagem da sombra do homem afirmando, "do que eu preciso, nem você nem ninguém pode dar”.

Um raio e planos muito rápidos de cruzes. O homem sentado fora da barraca, coberto com o cobertor, bebendo compulsivamente o chá. Mais planos de cruzes. Gritos. O homem sofre, os gritos aumentam. Uma cruz no alto. Os pés do homem na rua. Ruídos. Cruzes. O som de uma metralhadora sendo acionada. Os planos subjetivos do homem são superposições de imagens de pessoas na rua e das cruzes do cemitério. Um plano fechado

91 Nesse momento, quando a pergunta pela identidade do culpável é feita, nota-se a intenção de evitar nomear seja uma pessoa, seja um grupo específico. No filme - e talvez em grande parte da cinematografia colombiana - os nomes de militares que comandaram ataques, o próprio nome das guerrilhas FARC, EPL, ELN, etc. ou dos paramilitares AUC, ACCU, etc. não são citados. Cada um destes grupos mistura-se no pronome pessoal plural eles.

92 Puerta Nueva, segundo o filme, é o lugar em Caquetá onde morava Mañe antes da morte dos pais. Ao procurar esta cidadezinha no atlas não a encontrei. Conclui que se trata de um lugar imaginário, que funciona dentro da lógica de silêncio do filme (o não nomear as personagens, os grupos militares ou à margem da lei) e, sobretudo, alimenta a ideia do filme ser real (no sentido desta ser uma situação possível), contemporâneo e ser uma ilusão do que já é tido como normal. Por outro lado, Puerta Nueva pode ser também uma forma de chamar o estado de Caquetá, porque está localizado no passo entre os Andes e a Amazônia. 
dos olhos-óculos do homem. Mañe o encontra e tenta tirá-lo desse estado de quietude. Ao voltar a si, o homem reconhece Mañe e vai embora correndo.

Mañe, desapontado pelas atitudes do homem planeja um crime. Reza, pede proteção e ajuda à virgem ${ }^{93}$. Mañe, na sua insistente vontade de criar um laço de amizade com o homem, rouba a planta que ele utiliza para fazer o chá. E como se as preces do aleijado fossem ouvidas, o homem vai procurar sua ajuda. Sentindo a vitória, Mañe tenta arrancar uma confissão de amizade. O homem, já descrente, amaldiçoa-o e afirma com dureza que não precisa da ajuda de ninguém e vai embora. Mañe, sentindo-se culpado, sai com a planta nas mãos com a intenção de devolvê-la. Por azar encontra os jovens que constantemente o atacam e, desta vez, roubam a planta. Não contentes ainda tiram sua perna artificial e a jogam para longe, testando sua capacidade de se levantar. Mañe no chão, sem a perna, grita, pede aos jovens para que voltem e o enfrentem. Já de manhã, Mañe recupera a perna e assustado sobe a colina para oferecer sua ajuda ao homem. Floriculturas são visitadas, em nenhuma delas encontra a planta e Mañe ouve o que tanto queria, o homem declara que se sente amigo.

Quanto uma declaração de amizade pode ser cruel? Até onde quer Mañe saber da verdade do homem?

Tal ato de criminalidade tem uma consequência feliz. Porém, antes, no caminho à casa, Mañe encontra os jovens, ameaça-os, e como se não medisse suas forças com o bastão bate nas costas de quem parece ser o líder. Mañe é agredido violentamente pelos jovens, a câmera com um enquadramento muito distante se afasta desse ato cruel. Em casa, Mañe recebe os cuidados de Doña Marelvis, quando o homem da cadeira chega e arrependido pelo comportamento agressivo, afirma que está disposto a oferecer seu passado. Agora que o homem considera Mañe um amigo, entrega a caixa preta nas mãos de Mañe. É uma fita de VHS. Play.

Os dois sentados na cama diante do televisor. A tela se reflete nos óculos deles. Mañe

93 Uma cena que lembra sutilmente o filme La virgen de los sicarios (2000) de Barbet Schroeder, onde a imagem da virgem é a imagem mais louvada pelos "sicários" - assassino assalariado -, é ela quem cuida deles, das suas façanhas, dos seus mortos e da sua vida sempre em risco. 
curioso e o homem inexpressivo. "Filmando!", ouve-se. O rosto de uma mulher triste, despenteada e com os olhos para baixo. A câmera é instável e a mão de quem parece ser um jornalista tenta a acalmar. A voz que acompanha a mão pede um relato do que aconteceu. $A$ mulher está chorando, a voz quebrada, o gesto de sofrimento. "Ele pegava a gente, um de cada família. Cada família que era indicada para ele. Depois ele os colocava lá, ajoelhados, pedia para darem as mãos uns aos outros, e depois os assassinava”. O homem continua inexpressivo. "Como ele os assassinava?", pergunta o jornalista. "Ele colocava a arma aqui no queixo ou aqui na papada". A mulher indica com o dedo o lugar onde a arma era colocada. O sofrimento para falar dessas coisas é enorme, ela começa a falar rapidamente como querendo acabar logo com esse ato-relato, ao mesmo tempo, em que quer contar o que viu. Diante da pergunta "quem foi?", ela se altera, e responde como se fosse uma coisa óbvia, que o responsável era o assassino deles... a mulher assinala com a mão um ponto longe, no cume da montanha, ela não sabe dizer quem são eles. O jornalista, no seu afã de informação, mostra uma fotografia e pede para que a mulher reconheça o assassino. "É ele! Aquele que está lá na montanha. Ele não é homem, é uma besta... é o demônio mesmo!", afirma. A falta de compaixão e os gestos do assassino transformam-se em gestos de dor no corpo da mulher. Um rosto desfigurado pela visão daqueles atos. A presença do assassinato da sua família e a interrogativa da sua sobrevivência. Um homem de rosto oculto dava ordens que não foram atendidas pelo executor das mortes. Um ato gratuito que lhe deu alguns minutos a mais de vida para que assistisse à tortura de seu avô pelas mãos destes demônios. "Ele", diz a mulher, "carregou o velho quase morto em uma cadeira feita de madeira que levava nas costas". Ao ouvir a descrição da mulher, Mañe surpreende-se, leva as mãos à boca e faz um gesto de espanto. Um rosto desfigurado pela verdade. A mulher só sabe que o homem não quis atirar nela, que o avô está com eles e que o resto do grupo correu atrás do líder. A mão do jornalista faz um gesto à câmera para indicar o corte.

Mañe cobre seus olhos ao ouvir o barulho do final da gravação, permanece alguns segundos em silêncio e com ódio pergunta ao homem se foi ele o autor disso. O homem, imóvel, não responde, olha para a tela. Mañe grita, exige uma resposta, pede uma explicação. Porque ele lhe mostrou o vídeo? Com um empurrão joga-o no chão.

O filme dentro do filme é uma estratégia utilizada para fazer citações ou referências que 
estabelecem vínculos com o espectador (cinefilia), inserem comentários ou mundos extra diegéticos (sonhos, alucinações, desejos), elaboram o pensamento e a biografia do personagem (flashback). Em certos casos, conseguem criar um deslocamento em relação ao filme principal. Este deslocamento pode ter como proposta o estabelecimento de outro ângulo de visão para entendimento do próprio filme que consiste em representar o filme dentro dele mesmo. Uma das consequências deste deslocamento é a consciência do caráter artificial do filme, ou seja, o espectador é confrontado à sua posição de espectador e o filme expressa que é um filme. O que acontece quando as duas personagens assistem a fita VHS, é que o homem da cadeira é levado do mundo da ficção para a realidade ${ }^{94}$, ou seja, de uma personagem que não existe na rua de Bogotá passa a ser um assassino, "uma besta, um demônio" que está nas montanhas. No entanto, essa realidade que existe dentro do filme alimenta a diegese: dá um passado ao homem, responde às perguntas de Mañe. Como foi dito anteriormente, este testemunho é cotidiano graças aos noticiários, porém, no contexto do filme adquire outro estatuto, não de verdade (prova, informação, dado), mas de arte que desloca a forma naturalizada de ver a realidade:

A arte tem condições de iluminar o que está ao redor de modo mais imediato com a obrigação de produzir um corte pelo estranhamento, que desvie a percepção do seu hábito e a desarraigue do solo tradicional do sentido comum. Colocar em questão aquilo ao que estamos acostumados é a condição de um conhecimento dos objetos mais próximos, aqueles que ignoramos porque permanecem ocultos pela familiaridade que os recobre (Sarlo, 2005, p. 53, tradução minha).

Esta citação de Beatriz Sarlo (2005) sobre a capacidade da arte de oferecer outro conhecimento sobre o que é familiar é importante se pensarmos em sua discussão sobre o valor que hoje é dado à subjetividade em contextos de recuperação de memória. Para ela, o valor da voz, da experiência íntima, hoje organizada e circulada em forma de relatotestemunho, funciona como prova de um passado violento que pode agir contra o terror (ela está pensando sobre a ditadura argentina, mas a discussão é útil nos países com situações de violência e processos de reconstrução). Este relato-testemunho da vítima é suscetível de ser questionado, não pela experiência que comunica, mas pelas redes que alimenta. Redes que, segundo Sarlo, são as do mercado, da "história massiva de impacto público" (ibid., p. 15),

94 Da mesma forma que um diretor de cinema se representa a si mesmo em um filme no papel de diretor, como no filme La nuit americaine (1973), onde François Truffaut atua no papel de um diretor de cinema, Ferrand. 
cujo efeito mais perigoso é o de fechar "o caso mais monstruoso da nossa história" (ibid., p. 24). A proposta é de difundir e contar estas narrativas da experiência do terror para não repetir o passado, rememorando-o. Porém, a rememoração, não é suficiente, corre-se o risco de monumentalizar a história, de fazer dela uma coisa para ser vista e não para ser pensada. É necessário manter certa instabilidade do relato para que continue sendo surpreendente, instigante, tanto para o pensamento sobre o passado, como para as formas que utilizamos para inventar o futuro e elaborar o presente.

Preocupado com o estado de saúde do homem, Mañe o leva de volta ao hospital. A notícia da morte iminente é recebida em silêncio por Mañe. Alguma coisa que o homem utilizava o mantinha com vida, agora que não a utiliza mais, só lhe restam poucos dias de vida. Mañe volta para sua casa e recebe a notícia da fuga do homem. Pensando que o encontraria na barraca, para lá se dirige. Encontra o fogo a consumindo. Volta para o quarto, lá Doña Marelvis o encontra e querendo animar o inquilino lhe dá uma surpresa: a planta! Relembrando sua culpabilidade deixa-se cair em uma cadeira da sala. Agora, encontrar o homem é obrigatório. Mañe inicia um percurso pelas colinas de Bogotá. Com a planta na mão e a preocupação no rosto, ele é o culpado pelo sofrimento do amigo. Este ato de amizade é pontuado pela sonata de Schubert, tal como aconteceu em cenas anteriores. Moradores destas colinas indicam caminhos. Mañe sobe e sobe a colina, afasta-se a cidade barulhenta, a vida rural destas pessoas se faz presente ${ }^{95}$. Finalmente encontra o homem deitado na grama, o leito de morte.

Mañe começa a fazer o chá. O homem pede a gritos a solidão. Mañe, firme, pede uma verdade. Em um ato corajoso, conta sua verdade, confessa que ele roubou a planta, que essa foi uma estratégia para que o homem confiasse nele. O homem repele a presença de Mañe, ele apagou seu rastro para não ser perseguido. Absolve-o da culpa e pede para que vá embora. Mañe bravo recusa o pedido. Ele quer um passado, quer uma verdade, seja qual for, não é importante quem nem quantos matou, ele é seu amigo. Um plano em plongée fechado

95 O filme tem a qualidade de apresentar a cidade de Bogotá, os trajetos do homem levam o espectador por uma cidade desconhecida. Embora o cenário seja o centro da cidade, um ponto de referência, as imagens mostram dimensões ignoradas pela familiaridade dos bogotanos com o centro. Este trajeto de Mañe pelas colinas é uma imagem desconhecida, uma Bogotá ao avesso, o rural, a montanha, características que contradizem a imagem urbana da cidade. Outro filme tem essa particularidade, trata-se de Buscando a Miguel (2007, Juan Fisher), que narra a história de um jovem político que perde a memória e se torna um catador de lixo. Esta vida marginal na rua apresenta dimensões e lugares ignorados da cidade. 
sobre o rosto do homem moribundo, "você esta disposto para me escutar?"

"Sim!”, grita Mañe. "Matei muitas pessoas" Silêncio. Com a mão direita retira os óculos, o rosto é revelado. "Anciãos, crianças, mulheres, grávidas. Quando a gente começa a matar, a gente se acostuma." Os olhos ainda fechados e um gesto de dor e ódio no rosto. "é feito sem pensar, sem sentir e depois de tanta morte não fica mais nada". Abre os olhos e dirige o olhar para Mañe. Este parece impressionado pela visão desse rosto transformado pela exposição dos olhos. "Você sabe o que é tirar a gente do campo e levar a gente para a montanha, ainda criança; você sabe o que é passar de transportar pessoas de um lado para outro do rio à matar na selva. Você não sabe disso" Os olhos fechados. Mañe sério olhando fixamente para o amigo. Uma luz ilumina o rosto do homem. Ele era um bom assassino, matava sem compaixão, sem culpa, no final das contas, não eram seus mortos, eram trabalhos, ordens. Respira, procura forças, restam-lhe poucos os segundos de vida. Abre os olhos. Visão horrorosa! A morte está diante dele!. Lembranças de outras mortes estão diante dele. "Sabe, eu também estive em Puerta Nueva". O reconhecimento incrédulo de Mañe. "Eu dirigi esse ataque”. Desgosto e tristeza, Mañe vira as costas e começa o caminho de volta para a cidade, mas se detém e o homem conta o que aconteceu: Nesse dia os chefes tinham marcado um encontro. A câmera agora está fixa no rosto de Mañe, que olha para o fora de campo, ao fundo, atrás dele, está o homem. O Sargento Jaimes soube de tal encontro - a pessoa que cobrava o aluguel perseguiu o homem da cadeira para matá-lo - e como lá estavam as famílias dos chefes, os encarregados pela segurança do grupo foram obrigados a acabar com o lugar (para não serem atacados primeiro pelo Sargento). A loucura foi tamanha que acabaram com a vida de todos na cidadezinha, assassinaram até os que estava no Hospital Militar. Os olhos abertos. "Matamos todo mundo, as pessoas, os vizinhos". Abre os olhos, a dor invade seu corpo, vira os olhos para a direção de Mañe. "Seu pai, sua mãe". De novo o plano sobre Mañe que fecha os olhos, sofre. A culpa do descontrole era do homem. O Sargento foi retirado do serviço militar e ele foi justiçado. Os indigenas lhe deram uma planta para a dor, e cuidaram dele até que se recuperasse e pudesse iniciar o caminho até Bogotá, com a planta, para começar de novo. "Você sabe o que é começar de novo? Fazer a mesma coisa que eu fazia lá, transportar pessoas de um lado pro outro. Começar de novo. Mas sabe o que, irmão?. O pior foi encontrá-lo. Isso foi o pior. É como se todos esses mortos tivessem voltado, de novo." À pergunta do porquê mostrar o vídeo, o homem responde que esta é a única prova do que ele fez, as pessoas que participaram do vídeo, morreram depois 
pelas mãos do homem, assim o silêncio estaria assegurado. Mas, Mañe, tinha que saber, porque ele era a única pessoa em quem o homem pode confiar. Mañe nega o perdão. $O$ homem sabe bem que não existe perdão para eles. O sangue sai da orelha, o homem levantase e continua seu caminho, a cada passo, gritos e a metralhadora. Até a morte.

Mañe deixa cair algumas lágrimas, agora ele sabe: tem certeza sobre quem matou os pais e conhece os detalhes sobre o passado do amigo. Suas perguntas foram respondidas. $\grave{A}$ noite, Mañe enterra-o com a cadeira, o vídeo fica em suas mãos e o presente, a figura de origami, guardará a tumba do homem.

Bogotá, que não sente a falta do homem, vive um dia como qualquer outro. Mañe caminha pelas ruas com a planta, olha a cidade. O plano dos olhos-óculos de Mañe é similar ao plano dos olhos-óculos do homem. Mañe tira os óculos e os guarda no bolso da calça. Algumas pessoas distraem os pedestres com malabares, outras oferecem mercadorias. Um saxofone repete algumas notas. O desenho do homem, isolado, colocado no mesmo espaço que ocupam os outros desenhos desta galeria de personagens famosos e transeuntes.

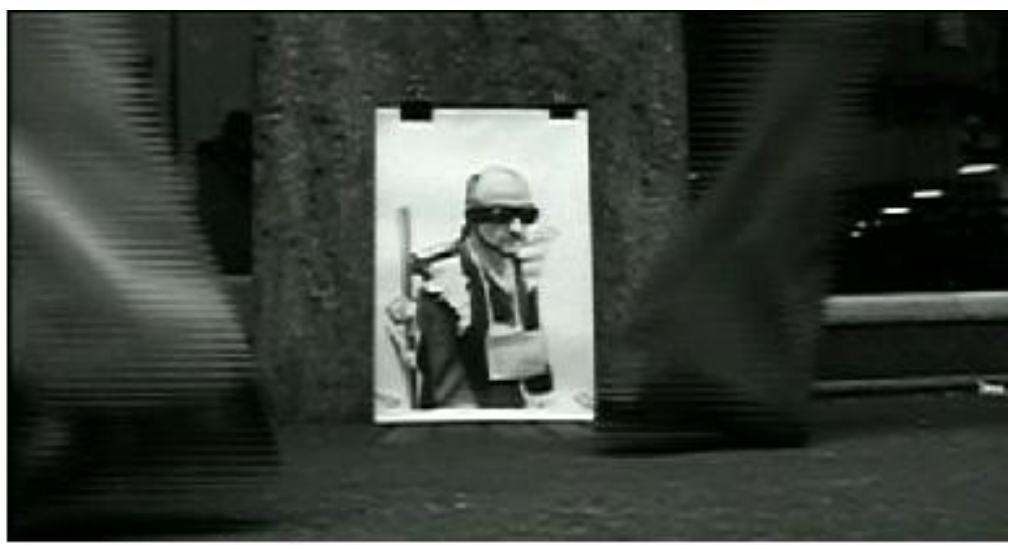

Frame. La sombra del caminante (Ciro Guerra, 2004)

O filme cria uma situação em que imagens de si e do outro são circuladas e espelhadas uma na outra com o fim de produzir mudanças no estado das coisas. $\mathrm{O}$ espectador é chamado a participar desta visão ideal por meio da identificação e deslocamento proposto no filme. As personagens são ambíguos e estão em constante transformação. O homem com os óculos é um ponto fixo, suas emoções e gestos são mínimos e previsíveis, seu silêncio e os olhos cobertos são instigações a olhar. As perguntas de Mañe - que bem poderiam ser as perguntas do 
espectador, ou as de um juiz - na sua vontade de conhecimento e seu afã de estabelecer um vínculo com o homem, abrem uma fenda que libera o passado violento e deformam o ponto fixo que era o homem. O final do filme não seria um reconhecimento da vítima e o perdão oferecido ou negado, como poderia ocorrer no espaço de mesas de negociação ou em um tribunal de justiça, ou, em um confessionário. O final é a liberação da energia negativa da dor e da verdade que por alguns instantes cria as condições necessárias para a fala, oferece um relato e expressa uma posição diante de tanta maldade, uma cura.

O filme oferece um tipo de cura não porque ele resolva a situação que inspira o filme ou porque a vida das personagens tenha um final claro. O filme pode ser pensado como cura no sentido de Taussig (1986) porque é um "encontro de contrastes que desfazem a vida para engendrá-la de novo" (ibid., p. 416). Isso, pela montagem - cuja habilidade para "provocar conexões repentinas e infinitas entre dissimilares em um interminável, ou quase interminável, processo de fazer conexões e romper-conexões" (ibid., p. 441) -, mas, sobretudo, o filme constrói uma "imagem da verdade como experimento" (ibid., 445), nunca completo ou definitivo.

A figura do homem, sem nome e sem olhos, com uma cadeira nas costas, o artefato que lhe dá a condição de começar de novo. Fazer o mesmo que fazia antes, carregar pessoas de um lado para o outro, na cidade. Começar de novo, não como uma invenção de uma vida, mas como a recuperação de um passado. Uma atividade extraordinária, em comparação com a vida urbana de Bogotá, que por opção ou por negação coloca o homem em posição de subjugação, ele carrega sua vítima nas costas, sente seu peso real, físico e é obrigado a lhe servir até chegar ao ponto final. O homem deve carregar essa história de violência para contá-la e olhar no rosto da vitima, tornar-se humano. Interpelar as imagens cotidianas do público sobre a realidade e a verdade da nossa violência colombiana. 
Capítulo 2

Quanto dura o terror? 


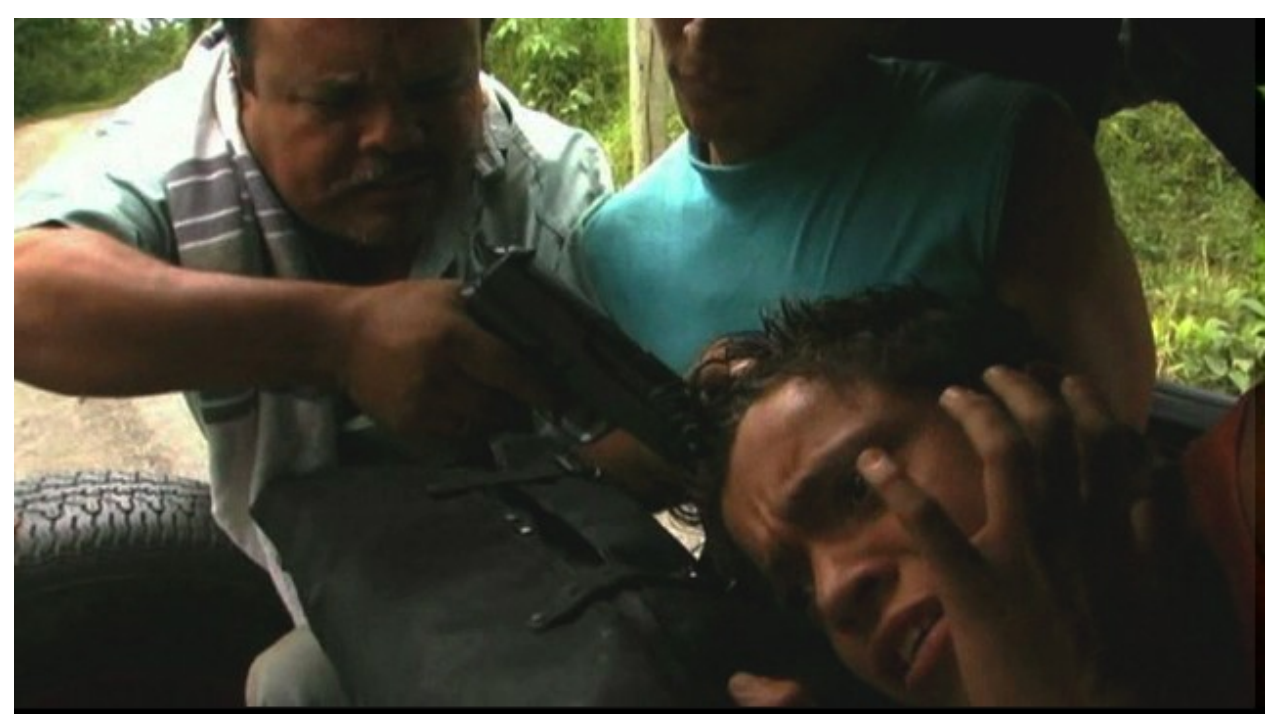

"How does one percieve during and after chronic political violence?

What knowledge emerges from the terror zones, and at what cultural sites does it

$$
\text { appear? }
$$

Where does violence emerge into visibility, and what visibilities does violence

$$
\text { create? }
$$

What are the perceptual and somatic coordinates of political depiction and imagining [...]?” (Feldman, [1997] 2000, p. 51)

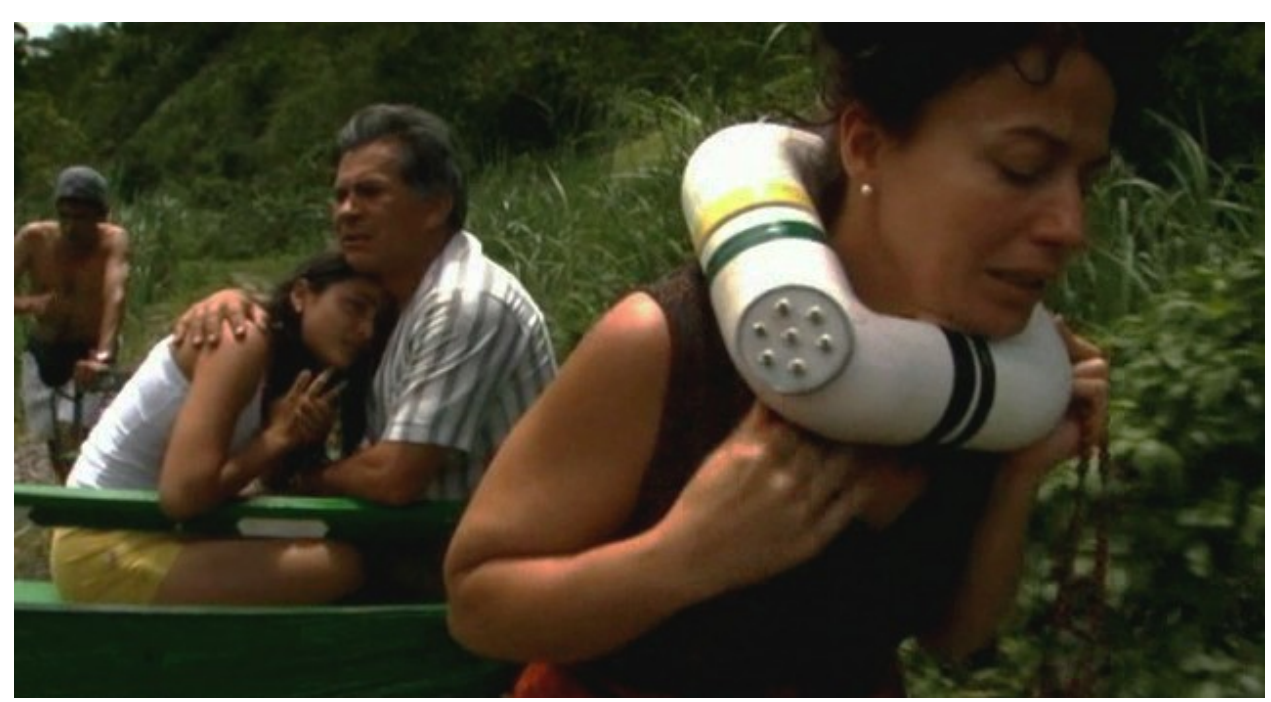

Frames. PVC-1. (spiros Stathopoulos, 2007) 

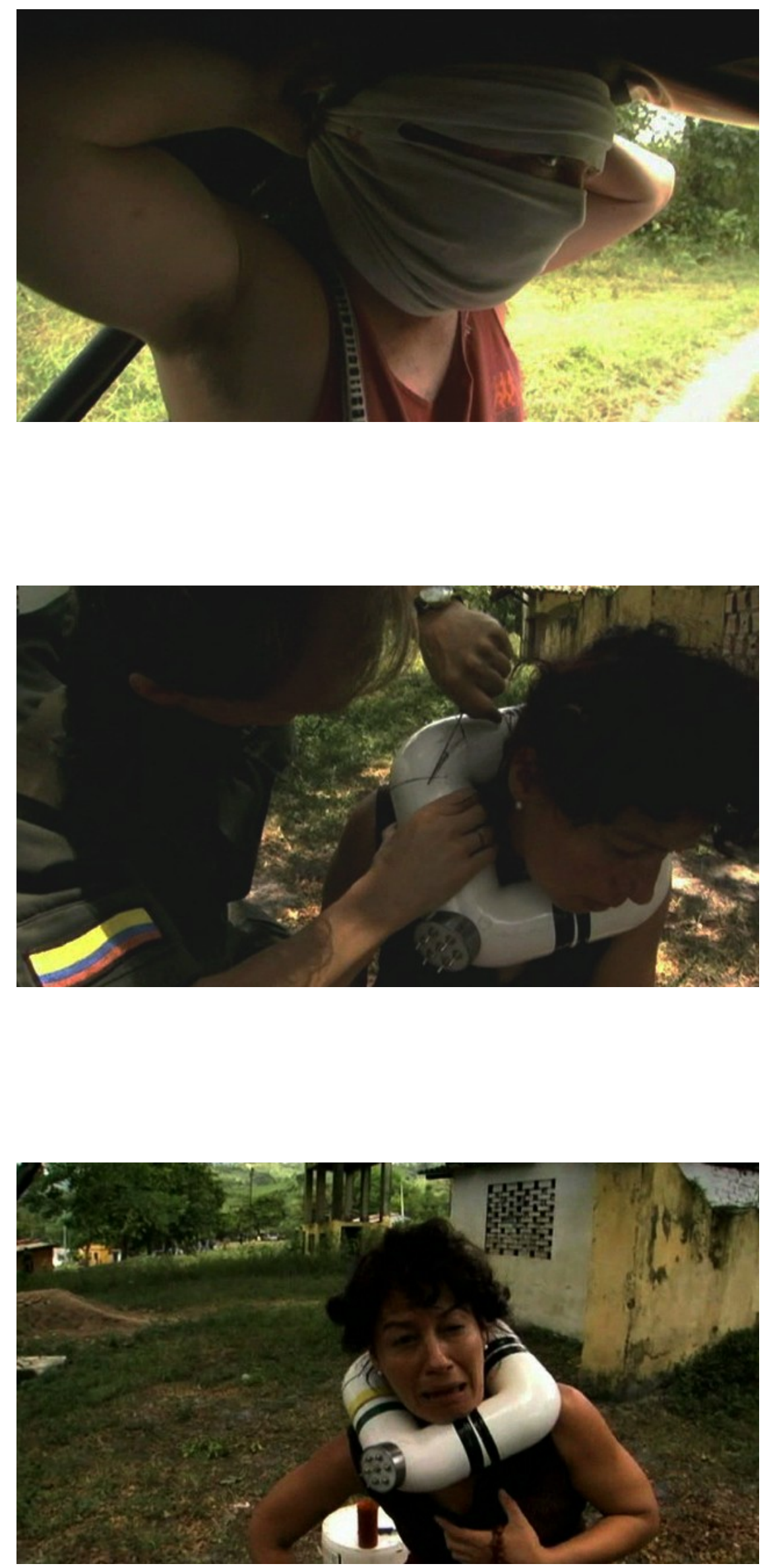

Frames. PVC-1. (spiros Stathopoulos, 2007) 
A família de Ofelia (Mérida Urquiza), Simón (Daniel Páez) e seus três filhos (Ivón Cadena, Liz Pulido y Camilo Lamus) é atacada no sítio onde moram por um grupo de criminosos, liderados por Benjamín (Hugo Pereira). O grupo vai extorquir a família, exige o pagamento de \$ 15 milhões (7.000USD) e, para assegurar a entrega da soma total do dinheiro pedido, em sigilo e sem avisar as autoridades, colocam um colar-bomba no pescoço de Ofelia. A família se opondo às indicações dos agressores, procura a ajuda da polícia antiexplosivos para desativar o aparelho. $\mathrm{O}$ agente de antiexplosivos retira o acionador químico, mas a promessa de um final feliz é revestida das lágrimas de uma filha deixada órfã.

Este filme é a primeira obra realizada pelo diretor Spiros Stathoulopoulos. É uma proposta original de linguagem fílmica que chama a atenção para as possibilidades desta linguagem manipular o tempo e o espaço de tal forma que a tensão experimentada pelo medo alheio, pode chegar a ser vivenciada pelo espectador, obrigando-o a manter o olhar na cena. Não lhe seria permitido fechar os olhos ou mudar de canal.

Neste capítulo, será analisado $P V C$-1 um filme realizado em um plano-sequência (sem cortes) de 85 minutos, dirigido por Spiros Stathoulopoulos, lançado em 2007 e acolhido com grande sucesso em diversos festivais nacionais e internacionais de cinema ${ }^{96}$. Depois desta circulação e do lançamento do DVD nos Estados Unidos, o filme estreia na Colômbia em $2008^{97}$. A crítica recebe o filme com aplausos graças aos prêmios que recebeu no ano anterior e com interesse pela proposta artística da obra. Para Omar Rincón (2009), crítico de televisão, o valor deste filme estaria unicamente nos elogios que recebeu nos festivais - na chave de um "orgulho nacional" -, por outro lado, surgem opiniões que colocam este filme como sendo parte de uma renovação do cinema colombiano e dotado de grande qualidade técnica (Parra,

96 Prêmios Nacionais: Fondo de Desarrollo Cinematográfico; Ministério de Cultura de Colombia, 2007; Premio de Post Producción. Prêmios Internacionais: Festival de Cannes 2007; Prêmio Cidade de Roma, Melhor filme Iberoamericano; Festival Internacional de Bangkok 2008, Grand Prix, Kinnaree de Oro a Melhor Filme do Festival; Melhor Filme Iberoamericano, Premio Città di Roma (Italia); entre outros. Informações retiradas

de: http://www.proimagenescolombia.com/secciones/cine colombiano/peliculas colombianas/pelicula plantilla. php?id pelicula=1796. Acessado em 08/2011.

97 Em entrevista realizada com o produtor do filme, Vassilis Stathoulopoulos, soube que este duplo lançamento foi motivado por uma vontade de fazer circular e vender o filme antes dele cair nas redes - colombianas - da pirataria. Bogotá, Colômbia, janeiro de 2011.
\end{abstract}


2009). As críticas e um pequeno debate que qualificou o filme como uma encenação do caso de 2000 da colocação do colar-bomba em uma mulher em um povoado entre Simijaca e Chiquinquirá, (no departamento de Boyacá ${ }^{98}$ ), deram ao filme uma certa importância que não se traduziu em bilheteria ${ }^{99}$, mas no interesse de um público especializado: cinéfilos, críticos de cinema e estudantes.

A pré-produção do filme foi árdua. $O$ diretor afirma que queria fazer um filme independente e com poucos recursos econômicos (PVC..., 2007). Assim, todo o peso criativo voltou-se para a filmagem (Con la cámara..., 2008). Como a proposta foi de simultaneamente filmar e produzir o longa, a narração acontece só diante da câmera e por uma única vez (a equipe fez 4 tentativas de filmagem, as 3 anteriores erraram, a última é o filme ${ }^{100}$ ). Houve uma preparação prévia não só dos atores (diálogos, gestos, emoção e posições no quadro), mas também do diretor (Spiros teve que se preparar fisicamente para carregar um equipamento de quase $15 \mathrm{~kg}$ durante os 85 minutos de filmagem) e do terreno: a locação é um sítio que fica em Villeta, uma pequena cidade localizada a 2 horas ao nordeste de Bogotá, cujo terreno precisou ser modificado para recortar os caminhos e conseguir dar a sensação de deslocamento, sem quebrar o plano nem modificar a duração do filme.

Os atores provêm de diferentes meios: os que dão vida às personagens dos filhos de Ofelia e Simón, bem como os agentes da Cruz Vermelha, os agressores, militares e policiais pertencem ao teatro Samán (Gómez, 2007), um local onde funciona um importante grupo cultural da cidade onde foi realizado o filme. As personagens principais - Ofelia, Simón e Jairo - são atores profissionais de teatro e o líder do bando de agressores é um dos moradores de Villeta. Houve, pois, um esforço por articular distintas experiências e trajetórias de atuação, o que significa um trabalho de preparação do ator e que resultou na criação de um filme que deposita uma grande confiança nas capacidades de cada um para construir estas

98 A vítima, Elvira Cortés foi assassinada por um grupo ilegal armado (ainda não há certeza se se trata de guerrilhas, paramilitares ou de grupos criminosos). Este grupo colocou um colar bomba na mulher com o objetivo de extorquir seu marido. O jornal colombiano "El Tiempo" seguiu de perto o caso e as informações sobre o desenvolvimento do caso. Estas podem ser lidas no site http://www.eltiempo.com/archivo/cronologico?

$\mathrm{q}=$ collar+bomba\&producto $=$ eltiempo\&Submit + now. $\mathrm{x}=0 \&$ Submit + now. $y=0 \&$ Submit + now $=$ Submit + now . Acessado em 01/2011.

99 O filme teve uma média de sete mil espectadores, para um total de 2.217 .753 espectadores de cinema colombiano, e 21.561.926 de espectadores de cinema em 2008. Informações retiradas de http://www.proimagenescolombia.com/secciones/cine_colombiano/estadisticas/cine_colombiano.php. Acessado em 08/2011.

100Entrevista com Vasilis Stathoulopoulos, produtor executivo do filme, na cidade de Bogotá no dia 20 de Janeiro de 2011. 
personagens $^{101}$.

PVC-1 encena um fato real. Porém, o filme não se propõe como uma representação do evento: não vemos alusões ao lugar, datas, nomes ou homenagens in memoriam. A família de Elvia Cortés ameaçou impor uma demanda judicial contra o diretor, porque lhes pareceu que ele estava se apropriando de uma dor íntima para produzir o filme. Sem permissão para encenar o evento dramático, Spiros Stathoulopoulos teria feito um uso antiético dessa história além de submeter a família à tensão de rever as imagens da morte da mãe (familiares..., 2008). O diretor respondeu: "minha intenção era que ficasse na memória e não se desvanecesse. Porque me parece injusto que alguém seja morto desse jeito e que ninguém se lembre disso, não o respeite como merece. Não é só uma crítica à violência, é também à insensibilidade, à falta de empatia" (Con la..., 2008). Este filme era uma criação da ficção que não teve nenhum cuidado biográfico ou histórico, era também uma forma de se posicionar diante de um evento e teria seguido um procedimento criativo comum: o de fazer da realidade ficção. E mais, o diretor assegura ter se emocionado com as imagens publicadas nos jornais colombianos no ano de 2000, mas, tragédias similares ocorridas na Venezuela e em Chicago forneceram elementos para construir esta encenação. O filme então, não é reportagem nem re-encenação, é uma obra que por meio de uma particular elaboração do tempo comenta a forma pela qual os atos violentos são mostrados à sociedade.

Ao justapor a elaboração artística do diretor e as notícias produzidas sobre o fato, podemos ver que Spiros deseja retirar o evento do colar-bomba do fluxo de informações jornalísticas, porque estas amalgamam o sofrimento desta mulher ao mundo político para de certa forma, favorecer posições políticas particulares. Especialmente para criticar o governo do presidente vigente nessa época, Andrés Pastrana. O ano de 2000 começa com a notícia de trégua das guerrilhas das $\mathrm{FARC}^{102}$, depois de dois anos de negociações de paz com o presidente conservador Andrés Pastrana, que teve como condição a criação de uma zona de despeje, ou seja a desmilitarização de cinco municípios localizados entre Meta e Caquetá (uma região entre a Orinoquia e o Amazonas, onde é cultivada a coca e produzida a cocaína).

101 Em uma entrevista realizada ao diretor no ano de 2007 dentro das atividades da sessão não competitiva do Festival de Cannes, "quinzaine de directeurs" Spiros S. Afirmou que o trabalho com o grupo de atores foi muito exigente, pois eles deviam não só responder ao ritmo fílmico como manter a emoção. Ver: http://www.quinzaine-realisateurs.com/gallery.php? $\mathrm{r}=10141$. Acessado em 08/2012.

102 Fuerzas Armadas Revolucionárias de Colombia (FARC), grupo guerrilheiro marxista-leninista de orientação agrariana. Organizado na década dos anos 1960, principalmente, pelo líder Manuel Marulanda Vélez, apelidado de Tirofijo. 
Uma situação controversa, pois deixaria um amplo território sem presença das forças militares totalmente em mãos das guerrilhas, o que gerou desconfiança entre a opinião pública pela flexibilização do governo frente aos pedidos das guerrilhas e pelas denúncias feitas por organizações de direitos humanos, dos abusos pelas FARC realizados nesta zona de despeje (Gonzáles et al., 2002, p. 75-96). Este processo foi instável, as guerrilhas não apresentavam uma posição definitiva, os paramilitares atacavam o processo e o governo não tinha os meios para responder às demandas das guerrilhas: liberação de presos, manutenção da zona de despeje e luta anti-paramilitar. Em meio aos ataques das guerrilhas a povoados e os contraataques dos paramilitares e militares, o caso de Cortés marcou uma referência naquele momento:

\footnotetext{
Uma vez que se estabeleceu que as FARC não tinham sido autoras do colar-bomba que matou duas pessoas no departamento de Boyacá, foi acordada a data para realizar a audiência pública internacional sobre cultivos ilícitos e meio ambiente. Assim como se restabeleceu o status político do ELN, em grandes parte graças à gestão da sociedade civil (ibid., p. 90, tradução minha).
}

Primazia do caso, que logo cedeu seu lugar aos eventos que se sucederam, como o sequestro do deputado de Antioquia Guillermo León Valencia, irmão de Fabio Valencia Cossio um dos negociadores do governo, para protestar pelo processo; as reuniões na Suiça com as FARC e o ELN para discutir a "humanização do conflito", a entrada dos paramilitares no povoado de Vallecito (Serranía de San Lucas, sul de Bolívar), e em cidades no noroeste do país, especialmente localizadas em Norte de Santander e Arauca para criar um corredor estratégico que unisse essas regiões. Em novembro de 2000 os paramilitares sequestram sete congressistas, ainda protestando contra o governo e finalmente a suspensão da negociação por parte das FARC (ibid., p. 90, 91). O colar-bomba foi como um chamado de atenção sobre o recrudescimento das técnicas de violência e a perda de controle do governo do país, mas se perdeu entre o turbilhão de acontecimentos, como os massacres, deslocamentos forçados e desaparições que são notícia durante alguns minutos para envelhecerem e serem esquecidos no ritmo veloz da televisão e do mundo das notícias.

O diretor do filme não encena o evento como em uma representação fiel, mas as referências são claras e o choque que causou o filme foi, em parte, por este motivo. Sem entrar no debate, desejo ressaltar o filme como um esforço por retirar o evento da correnteza 
de notícias para lhe oferecer um tempo onde possa durar e ocupar um espaço próprio. A elaboração do tempo por meio das formas fílmicas é própria ao cinema. Esta característica não torna a discussão desnecessária, pois existem filmes com propostas que, além de construir uma mimesis do tempo real, elaboram uma temporalidade que se remetem a outros parâmetros. Tal é o caso deste filme, que em um plano-sequência de 85 minutos mostra o drama de uma mulher que carrega no seu pescoço uma bomba. O produtor afirma que é um interesse de Spiros pelo tempo:

O tempo para o ser humano, porque o tempo não existe. É a temporalidade na terra que é diferente para cada um, para as crianças passa mais devagar, para os adultos rápido e para alguém com um colar-bomba é mais rápido, implacável, não perdoa, avança (Vassilis Stathoulopoulos, Entrevista em Bogotá, janeiro de 2010, tradução minha).

Sem vontade de denúncia, o filme nos aproxima de uma experiência sensível. $P V C-1$ nos mostra a duração do medo por meio do plano-sequência, uma forma fílmica que coloca alguns problemas propriamente fílmicos: pode simplesmente ser um plano suficientemente longo, mas, se pensarmos em termos de montagem, ele obriga a admitir que existe montagem no interior do plano (Einsestein) e dificulta toda decomposição do filme. Esta impossibilidade de fragmentação, junto com a profundidade de campo, definiu o plano-sequência como instrumento de realismo (Bazin apud Xavier, 2005). Ou seja, seria transparente, por ser um plano sem montagem, que não manipula a imagem nem constrói mundos imaginários. $\mathrm{O}$ plano-sequência revelaria a "profundidade do real" onde as coisas significam por si mesmas e o espectador ocupa uma posição de testemunha (Xavier, 2005 p. 74, 75). Uma posição neorealista afirmaria que o realismo seria questão de "Captar a duração da dor real, da dor do homem e de sua presença diária, não como homem metafísico, mas como o homem que encontramos na esquina, e para o qual esta duração real deve corresponder a um esforço real da nossa solidariedade" (Zavattini apud. Xavier, 2005 p. 72).

Isso significa que o realismo não seria valorizado por seu naturalismo e sim pelo seu tom de crítica. O problema que a montagem propõe a esta posição é que define o cinema como artifício, como algo que lida com mundos de ilusão sem nenhuma referência ao mundo físico, real, imediato; o que na época no neorrealismo italiano era criticável, pois o cinema era tido com uma ferramenta para ver e pensar a Itália de pós-guerra (Fabris, 1996). Para além do 
realismo, as ideias de montagem no plano e a sequencialidade são utilizadas por Theo Angelopoulos, diretor grego de cinema, para pensar o plano-sequência como uma forma fílmica que elabora o olhar e uma poética da história (Barthélemy, 1997). Já, Andrei Tarkovski afirma que se trata de "esculpir o tempo", a elaboração de um certo tempo fílmico no qual a duração seria a forma de interpelar o espectador e uma forma de procurar uma "verdade psicológica" que é alcançada quando o cinegrafista se "afasta de verdade arqueológica e etnográfica" para apresentar o "passado para um público presente" (Tarkovski, 2002, p. 91). O cinema, para Tarkovski, é uma forma de explorar os problemas do mundo, a partir da observação e pela duração no tempo da imagem.

De modo que estamos diante de um filme que utiliza uma forma fílmica amplamente discutida e utilizada no cinema, o plano-sequência. Seu uso está tradicionalmente associado à representação da realidade (unidade do tempo e do espaço), ainda que tenham sido feitos usos que discutem esta posição (montagem interna). Neste filme o plano-sequência tem um uso bem particular, associado às possibilidades que oferece a tecnologia digital e a utilização de artefatos como o steadycam ${ }^{103}$. Um filme, que pode ser discutido nos termos de realismo, naturalismo e crítica à representação da violência, pode ser pensado no que tange à encenação do sensível. Um filme, enfim, cuja análise permite brincar com a ideia apresentada no primeiro capítulo sobre o lugar do espectador na tela e estender esta discussão para pensar temas como a memória do trauma e o conhecimento indesejável. As questões sobre o rosto e o olhar continuarão presentes e a escrita ou o problema de transformar em texto o que é imagem em movimento será objeto de atenção no decorrer deste capítulo. A realização deste filme em um plano-sequência junto à discussão da encenação da violência e uma vontade de fixar na memória o cruel, são temas que instigam uma aproximação crítica ao longa.

Voltamos assim ao problema inicial desta pesquisa, qual seja, a narração do terror pelo cinema. Narração que põe em contato o aquém (eu) com o além (imagem na tela), pela tatilidade do olhar e que elabora, deforma e ilumina um mundo cotidiano que exige ser olhado, contado e expressado de outras formas. A imagem como configuração possível da realidade, que abre espaços onde o impossível pode ser narrado, se torna transgressão das

103 Steadycam é o nome comercial de um artefato que serve para estabilizar a câmera. Este permite levar a câmera presa ao corpo de quem opera a câmera com um arnês. Serve para harmonizar os movimentos do operador, filmar planos subjetivos do personagem, substituir o dolly (máquina para fazer um travelling) e realizar movimentos complexos em movimento. 
margens do dizível e, como diria Taussig (1995) desperta a memória, estimula os sonhos coletivos, enfim, conta a história das nações, provoca visões e reações diferentes das que surgem quando nosso sistema de representação está adormecido. $P V C$-1, na mesma linha de La sombra del caminante, interpela e elabora realidades, com a particularidade de configurar um tempo sensível, ou a narração como um assunto de contato temporal com o terror.

No primeiro capítulo optei pela descrição do filme como método para me aproximar desta imagem, apresentando desta maneira uma visão possível do filme (a da antropólogapesquisadora). Os cortes na descrição respondem aos chamados de atenção que o filme ia propondo e não a uma fragmentação em cenas ou sequências claramente definidas por efeitos de montagem. Este filme, por ser realizado sem cortes - o sentido não surge da justaposição dos planos -, dificulta tal aproximação, pois o que constitui seu valor seria, desta forma, quando menos, ignorado. $P V C-1$ coloca este assunto em pauta: sendo este um filme sem cortes, com uma multiplicidade de planos (dentro do plano) e mudanças sutis de iluminação e angulação que ocorrem pela movimentação da câmera, como não fragmentar o que deve permanecer unido? Como dar conta da construção do tema, das personagens e do lugar sem retirar a dimensão temporal que define a especificidade deste processo?

Um tipo de análise como a proposta por Vanoye e Goliot-Leté ([1992] 1994) de desmontagem e reconstrução de acordo com as opções da análise, autoriza a fragmentação das sequências. Isto, considerando que um filme é uma união de fragmentos por meio da montagem, que lhe dão certo ritmo e sentido. No caso de $P V C$-1, trata-se de uma montagem interna que deve se pensar além da montagem definida por Sergei Einsestein ([1940] 2002): justaposição de planos. Para entender este tipo de montagem é necessário seguir atentamente os planos. Para isto, utilizei a ferramenta da decupagem, a decomposição em planos da sequência. Os cortes dependem dos movimentos de câmera e dos elementos que tal movimento coloca em relevo (primeiro plano, por exemplo). Este filme está construído por movimentos circulares que tem por eixo o personagem ou o objeto de interesse em cada cena, o deslocamento da câmera é justificado pelo deslocamento das pessoas, o som e o olhar; estes dois últimos utilizados como vetores. As sequências podem ser identificadas com as ações que identificam as quatro partes em que se divide narrativa do filme: 1) a chegada do grupo agressor, liderado por Benjamín, à casa da família de Ofelia e Simón, 2) entrada na casa e 
ameaça, 3) trajeto de Ofellia, Simón e Rosita até o local onde a bomba será desativada, 4) Jairo Hurtado, o agente de antiexplosivos, trabalha na desativação da bomba.

Contudo, não abandonarei a prática de descrição do filme, porém seu uso será diferente daquele efetuado no primeiro capitulo. Neste momento a descrição servirá ao propósito de comunicar uma ideia geral e clara do conjunto de imagens para depois apresentar fragmentos de cada sequência descomposto em planos. Não apresentarei a totalidade da decupagem nem todos os detalhes, pois isto não aportaria elementos à discussão, apenas inserirei partes das sequências que durante o estudo do filme se mostraram como mais relevantes: a chegada dos agressores e a desativação da bomba. Assim, começarei com alguns pontos sobre o tema do plano-sequência e do tempo, para pensar a afirmação do diretor sobre este filme ser uma forma de fixar na memória um ato de crueldade. Em seguida, refletirei sobre o tema do lugar do espectador na tela, com o objetivo de estabelecer pontos de contato com o filme $L a$ sombra del caminante e pensar sobre a estratégia narrativa escolhida pelo diretor. Finalmente, farei alguns comentários sobre um tema que foi se tornando, com cada visualização do filme, mais importante, a saber, a encenação da tortura e os limites do mostrável.

A raiz do problema não está nos filmes; está nas condições sociais e políticas que determinaram e têm determinado o espaço de intervenção para trabalhos dessa natureza, que enfrentam os desafios e limites próprios a uma produção cinematográfica que, empenhada na crítica, se recusa a assumir uma concepção instrumentalista da cultura popular ou não (Xavier, 2007, p. 193).

Aos colombianos não lhes é permitido perder sua capacidade de surpresa frente ao terror.

Primeiro foram os assassinatos de personagens como Rodrigo Lara Bonilla, Luis Carlos Galán y Guillermo Cano ${ }^{104}$. Seguiram a explosão de um avião, das instalações do DAS [Departamento Administrativo de Seguridad] e de shopping center em Bogotá e Medellín. Depois, foram os massacres dos paramilitares, um por dia, no ano passado [1999]. Aconteceu a partida de futebol das autodefesas com a cabeça de uma das suas vítimas, a confecção de um burro-bomba pelas FARC, o desaparecimento de um povoado, Machuca, pelo ELN. O degolamento massivo no El Salado pelas AUC e a incineração de policiais e civis no Fuerte pela guerrilha.

104 Personagens políticos importantes na luta pelos direitos humanos e contra o narcotráfico: Rodrigo Lara Bonilla, ministro de justiça, assassinado no dia 30 de abril de 1984 (El Asesinato...., 1987), depois de incisivas denúncias do narcotráfico (El crimen..., 2009). Luis Carlos Galán, líder político, assassinado em Bogotá no dia 18 de agosto de 1989, também por ter denunciado o narcotráfico (Punto..., 2011). Guillermo Cano, jornalista e diretor do jornal El Espectador, assassinado no dia 17 de dezembro de 1986 por narcotraficantes (25 años..., 2011). Destes três crimes só o de Galán teve solução, os outros dois, continuam impunes. 
E, como se não bastasse, os nove sequestros que acontecem diariamente na Colômbia e os quase 400 mil desplazados que deixou a violência no ano passado [1999]. minha).

Dinamite que talvez só o diálogo possa desativar (León, 2000, tradução

Duas citações que enquadram esta discussão. Xavier (2007) estuda o cinema de Glauber Rocha e sua estética da fome em termos de formulação de uma crítica à política e ao Estado brasileiro, a partir de uma concepção particular do cinema. No cinema de Rocha vemos que não há uma vontade de mostrar a experiência social da fome, porque o que o diretor propõe é criar uma relação de desconforto com o espectador, para obrigá-lo a ver e refletir sobre o problema (da fome, da pobreza, da violência). Pelo uso de elementos da cultura popular, uma montagem de cortes diretos, sem unidade do tempo e do espaço e a elaboração de alegorias, microcosmos que são segmentos do nacional ou alegorias do nacional. O que me interessa da proposta de Rocha e da análise de Xavier é a construção de imagens que estabelecem relações de desconforto com o espectador. Para eles, não haveria vontade de explicação ou representação de um evento ou personagem com cuidado histórico, e sim um uso criativo do real para criticar tanto seu uso pelo cinema quanto refletir sobre as condições sociais, políticas e históricas do presente.

León (2000), em tom de indignação, escreve sobre o crime do colar-bomba na segunda citação. Ela chama atenção sobre a fragilidade do processo de paz que acontecia naquela época na Colômbia. Mas o que me interessa não é esta questão, é a linguagem que ela utiliza para expressar sua comoção diante de um ato cruel, que ela insere em uma série de atos violentos que marcaram a história colombiana, pela sevícia do ato, e se pergunta pelo tipo de atitude que é capaz de imaginar e efetuar tais crueldades. Mas é a primeira linha que me ocupa, pois parece que para a jornalista este foi um "ponto final" o que significa dizer que o colar-bomba é a fragilidade do Estado, mas, sobretudo, é o limite da crueldade. "Aos colombianos não lhes é permitido perder sua capacidade de surpresa frente ao terror" ${ }^{105}$, diz ela, invocando o esforço de todos para ver e se surpreender, para não perder a sensibilidade pela familiaridade ou espetaculização que pode chegar a cobrir todos estes acontecimentos.

De modo que, por um lado existe a proposta de causar desconforto pela organização das

105 A jornalista utiliza uma redução estratégica para causar um choque no leitor. Ela se dirige especificamente aos seus conterrâneos e lista uma série de eventos dramáticos da história colombiana. Citei o fragmento do artigo para mostrar as palavras que são utilizadas para falar deste tipo de acontecimentos. 
imagens, pela montagem, por outro lado existe um chamado a se surpreender. Então, de que forma se estabelece a relação entre a crueldade, a forma fílmica e a vontade de gerar desconforto? $\mathrm{Ou}$, para citar as palavras do próprio diretor, a necessidade de fixar na memória pela forma fílmica o ato cruel, como fixar sem se acostumar, fazer com que a lembrança seja o desconforto.

\section{Plano-sequência}

O plano-sequência é uma das primeiras formas fílmicas (lembre-se dos curtas dos irmãos Lumière), utilizado principalmente em documentários (cinema direto) para não fragmentar os espaços nem os corpos ou produzir imagens muito similares com as do cinema de fícção ${ }^{106}$. É um recurso entendido como uma filmagem em tempo real que evita questionamentos sobre a realidade do registro, pois haveria uma relação direta entre o referente e sua imagem. Para Bazin, o plano sequência é uma forma fílmica que significa um "véritable réalisme", ou seja, um realismo verdadeiro "simultaneamente concreto y essencial del mundo" (Bazin, [1945] 1987, p. 11), que se opõe ao "trompe d'oeil", ou seja, às formas que "satisfazem a ilusão das formas" (Loc. cit). Em outras palavras, o plano sequência mantém a integridade do fato representado e revelando deste modo a "profundidade do real" (Xavier, 2005, p. 73), e não criando, a partir de um trabalho muito complexo de montagem uma "ilusão de realidade".

Ao pensar em $P V C$-1, estas considerações se tornam difíceis de sustentar, principalmente porque é um filme que é criado ao mesmo tempo em que é produzido (o filme não foi editado) e o que resulta desse processo, não é um tempo real, é um tempo experimentado por uma pessoa angustiada. As imagens e os deslocamentos rápidos não são mimesis de um tempo real ou de um trajeto humano, mas um jogo de lentes e de posições estratégicas do diretor (a câmera é uma HD, tecnologia digital) para fazer do tempo real (de filmagem) um tempo do sistema nervoso (da mulher).

106 Pense no cinema de ficção de Hollywood, totalmente voltado a produzir o realismo no cinema, o que se chamou de "ilusão de realidade", pela montagem de uma multiplicidade de planos, que teriam a qualidade de ser uma mimesis do olhar humano efetuada pela câmera e de configurar um espaço e tempo real. 
Sobre esta ideia do tempo nervoso vou discorrer mais longamente ao final deste texto. Primeiro, vou expor alguns pontos relacionados à tecnologia digital e sua importância na produção de um filme deste tipo e especificamente atendendo à produção do plano-sequência. Esta forma fílmica é de grande elaboração técnica que envolve posições de câmera, tripé, guincho, trilhos e capacidade histriônica dos atores para manter a emoção da cena e o ritmo da filmagem. Diferencia-se de um plano longo pela movimentação da câmera, pois, neste último, o único importante seria a duração e não a complexidade da tomada. Muitos planos-sequência passaram à historia, como a introdução do filme Touch of evil (Orson Welles, 1958), as sequências dos filmes Nostalgia (1983) e Sacrificio (1986) de Andrei Tarkovsky ou aquelas realizadas por Theo Angelopoulos. Foi o filme de Hitchcock The rope (1948) que desafiou a montagem e as condições técnicas da época e apresentou um filme aparentemente realizado na sua totalidade em uma tomada só. Os cortes no filme do mestre do suspense se devem a que, em 1948, os rolos de filme estavam divididos em dois mini-rolos de 10 minutos, de modo que cada quadro preto no filme é uma fusão de um rolo com o outro, esta junção de um plano com o seguinte, é perfeita e não distinguimos cortes. São grandes produções, o que lhes permite utilizar os equipamentos necessários a estas proezas cinematográficas e dependem da metragem contida em cada rolo para determinar a duração do plano.

A tecnologia digital liberou os artistas de muitas restrições técnicas, uma delas é principal: a película. Ao transformar metros de película em valores digitais capazes de registrar imagem e som de modo eficaz e mais nítido do que o cérebro humano, o registro não teve mais limites de tempo nem as limitações da película para a captação de uma cena com mudanças de iluminação. Ademais, esta tecnologia ampliou o uso das câmeras de vídeo e permitiu que jovens dirigissem seus filmes com baixos orçamentos, de forma independente e obtivessem qualidades plásticas impressionantes. Tal é o caso dos dois diretores cujos filmes são aqui analisados, mas é uma característica que saliento para o filme de Stathoulopoulos porque ele se utilizou de um recurso fílmico que ocupa um lugar privilegiado na cinematografia e realizou um filme totalmente sem cortes e com movimentos muito complexos. Um exemplo anterior ao filme deste diretor colombiano, é a obra do diretor russo, Alexander Sokurov, Russian ark (2002) - conceituado como o primeiro filme em planosequência da história do cinema -, que mostra o grande baile russo de 1913 a partir do ponto de vista de um narrador desconhecido.

Aumont (1983) afirma que a análise fílmica explicita um problema cinematográfico que 
um longa-metragem elabora. Logo, esta é uma proposta de chamar à discussão alguns críticos de cinema e realizadores que têm pensado (em textos e em filmes) sobre o plano-sequência, para entender a proposta de Spiros Stathoulopoulos. Este filme é um caso muito especial na cinematografia colombiana. Visto a partir da perspectiva técnica, o uso da câmera e dos dispositivos de filmagem fazem com que este filme dialogue tanto com um cinema estrangeiro como com um cinema colombiano no que se refere à forma fílmica e ao problema da representação da violência. $O$ filme permite chamar à discussão autores tão distintos e instigantes como os já citados, Andrei Tarkovsky, Theo Angelopoulos ou Michael Haneke, como também permite estabelecer relações com filmes colombianos como o de Ciro Guerra e a produção contemporânea de diretores que se preocupam com a estética da violência e sua encenação.

Uma bolsa preta parece atrair a atenção de todos no carro. A familia viaja por uma estrada de qualquer paisagem rural da Colômbia, o silêncio e o entorno natural cobrem uma tensão que se esconde nos olhares dos passageiros. O campo verde e as montanhas que circundam a paisagem dão a impressão de uma terra rica, de clima quente; destino de cultivos de camponeses e férias dos trabalhadores das cidades. De repente, gritos e ameaças e a exibição grotesca e descarada de uma arma abrem como que uma fenda no ambiente por onde a tensão pode ser liberada, e, surpreendentemente, guardada toda vez que se queira voltar ao estado inicial. À mulher que dirige o carro, Benjamin dá a ordem de parar e avisa aos outros que chegaram.

No sinal da chegada, todos começam a cobrir seus rostos. O grupo é formado por um homem adulto, dois homens jovens, um menino e uma mulher adulta. $O$ olhar duro de um para o outro, dá a impressão de que eles estão vigiando as ações, os gestos próprios e os dos outros, como se não houvesse lugar para o erro. Benjamín fixa o olhar duro nos homens, avisa que devem seguir o plano passo a passo como planejado, não devem errar, pois se trata de algo importante. Agora o líder começa a entregar armas: uma pistola para a mulher, outra para o homem de camiseta branca, facão para o menino, o líder guarda sua arma. Então, todos começam a cobrir o rosto, a mulher o homem, os outros dois e o menino. Todos descem do carro, arma em mão e os ânimos excitados: é uma incursão ilegal no terreno de alguém. 
Os primeiros 27 segundos são dedicados aos créditos de produção. Os 11 segundos seguintes, apresentam o título do filme. Um fade in deixa ver uma família que vai por uma estrada rural em um jeep vermelho. O som é o do carro, os tripulantes estão em silêncio e não há música. O primeiro tem uma camiseta verde, e segura nas pernas com as duas mãos uma bolsa preta, a câmera faz um movimento em panorâmica ${ }^{107}$ à direita e vemos agora um menino de uns 15 anos, que veste uma camiseta vermelha e olha para o fora de campo ${ }^{108}$, ele tem uma chave de fenda na mão e a faz girar com os dedos. O movimento em panorâmica continua à direita, agora vemos uma mulher que dirige, entra no quadro uma mão de um homem que toca a perna da mulher, ela o rejeita e a câmera segue este movimento, agora vemos um homem sério cujo olhar esta fixo no horizonte. A câmera continua o giro e encontra outro homem, que olha para o fora de campo, segue o movimento e vemos de novo, como se terminasse um ciclo, o primeiro homem de camiseta verde. Algumas características podem ser elencadas: o primeiro plano é igual ao último plano, a cena vai sendo desvelada pelo movimento, a ação está acontecendo antes do fade in inicial, o espaço é pequeno (um carro) e se localiza dentro de um espaço muito amplo que está em constante mutação (a paisagem, o espaço atravessado pelo carro) sem que isto amplie o horizonte de visão, não existe música (nem justificada pelo rádio do carro, por exemplo) o único ruído que escutamos é o do motor do carro, o olhar fora de campo denota um cruzamento de olhares, não justifica o movimento da câmera.

O movimento panorâmico da câmera é devagar e contínuo, depois do plano do homem de camiseta verde, segue o menino. Ele gira a cabeça para esquerda, abaixa o olhar e introduz a chave de fenda na bolsa. Nesse momento, o homem de camiseta verde grita, um grito de raiva para ele ficar quieto, o menino assustado retira as mãos. A câmera faz um movimento rápido para enquadrar o homem que está no lugar do copiloto, fixa o plano nele, que, muito bravo, grita e reclama como se um imprevisto deste tipo já tivesse acontecido. O homem manda parar o carro, a mulher demora para obedecer, ele grita, ela para. O homem olha para o menino, estira o braço e agarra o cabelo do menino, abaixa a cabeça dele para castigá-lo.

107 Este movimento consiste no giro da câmera no seu eixo, pode ser vertical ou horizontal. Tem o efeito igual ao que se produz quando se gira a cabeça.

108 O campo é tudo aquilo que está dentro do quadro cinematográfico, é o que é visível. O fora de campo e tudo o que está além do quadro, o que não é visto mas é de alguma forma inserido no campo: olhares, som, conversações, etc. 
Nesse momento todos gritam, pedindo para matar logo o menino, com exceção da mulher, que grita para o homem parar com a agressão. Neste momento ficamos sabendo que ele é o tio do menino.

O homem se detém, respira, abre a porta do carro, sai, a câmera com uma panorâmica à direita segue-o até o ponto em que ele está de frente à câmera na parte de trás do carro. Vemos que ele tem uma arma na mão, olha para um lado, olha para o outro, agarra a cabeça do menino e encosta a arma contra a cabeça dele, o menino tenta se livrar, grita e promete não agir dessa forma de novo, os outros dois continuam pedindo para matar o menino, até que um deles - o primeiro que vimos - os separa e o último homem mostrado, pede para Benjamín se acalmar, para parar com tudo isso, voltar para seu lugar e continuar o caminho. Outra série de características podem ser ressaltadas: a câmera faz movimentos mais rápidos e desorganizados nestes momentos de tensão, as personagens não são identificadas: o parentesco e o nome do copiloto são ditos de maneira muito breve, sem dar nenhuma atenção a este tipo de informação; o som dos gritos é alto em excesso, a exibição da arma não é enquadrada por planos fechados ela é simplesmente exibida, porém no momento da agressão a câmera se fixa e permanece o tempo inteiro no lugar do acontecimento, a ausência de um corte obriga a olhar para a cena.

Nestes primeiros 7 min 48 s é apresentada a estrutura circular que vai desvelando as cenas pelo movimento, e fechando-as quando a câmera chega ao ponto inicial (homem da camiseta verde, por exemplo). A sensação de que a câmera chega à ação e que esta se desenvolve em um lugar muito pequeno, em contraste com o espaço amplo que o circunda faz com que as cenas sejam asfixiantes e, a princípio desconcertantes. Ao não ter uma introdução mais clara, do espaço, nome e passado das personagens é difícil identificar a situação; a relação de parentesco entre o menino e o homem e o nome deste último são ditos no momento da agressão sem nenhuma marca que dê relevo a esta informação. É como se só importasse o presente, aliás, o momento enquadrado. Não sabemos de nomes nem de lugares, não escutamos música que nos dê uma noção de nacionalidade. A câmera faz movimentos mais rápidos e desorganizados nos momentos de tensão, como se se alterasse com os ânimos das personagens, ou seja, não é uma câmera que filma à distância, mas uma câmera que filma de perto, cujo fluxo está aliado ao da ação que se desenrola na cena. 
Se pensarmos esta construção a partir da perspectiva da proposição expressada em 1923 por Béla Balázs segundo a qual, "existe uma construção histórica da sensibilidade humana, uma dialética pela qual os instrumentos de trabalho e a relação com a natureza interagem com as formas de expressão do homem e sua linguagem" (Balázs apud Xavier, [1983] 2003, p. 22), podemos entender este filme como uma forma de recuperar uma sensibilidade diante dos atos cruéis que acontecem cotidianamente, que são publicados em jornais ou apresentados nos noticiários pela televisão. É como se fosse uma resposta ao chamado de não perder a capacidade de se surpreender, como também pode ser uma forma de mostrar para o público outras sensibilidades, que já não se relacionam mais com a contemplação da imagem e sim com o choque que esta pode causar. O que é sugestivo é que o choque não é questão de um instante, em $P V C$ - 1 o choque é questão de duração.

O grupo entra pela parte de trás de um sítio, cada um se esconde e vai avançando rapidamente até chegar na casa onde três crianças e um homem estão passando as horas da tarde. O grupo invasor aborda a família com xingamentos e ameaças, tirando dos quartos, um a um, com gritos e empurrões, os três jovens, obrigando-os a se sentar no chão no centro da sala. O homem da camiseta vermelha joga contra a parede um homem velho. Enquanto isto acontece, a câmera se afasta, sai da casa, de novo o silêncio de uma tarde tranquila no campo. Cavalariças vazias, em um chiqueiro três leitões dormem, o espaço parece não estar habitado. No final da cavalariça há um quarto e lá uma mulher que alimenta um pintinho; ela canta, dá de beber e o mima, ela está distraída na tarefa, ignorante do que está acontecendo noutro lugar da casa. De repente um grito! Um dos homens a agarra pelo pescoço, o menino que acompanha este grupo de agressores ajuda a empurrá-la contra uma parede e com o facão que leva na mão mata com excessiva violência o pintinho. Ela grita, pede para não tocarem a família enquanto é levada à força até o lugar onde se encontram os outros membros do grupo agressor e da família. Quando chega, todos já estão no chão, com as mãos amarradas, ajoelhadas e olhando para o chão. Ela é obrigada a se juntar aos outros. Choro, pedidos para parar com o barulho lamentável, súplicas para não lastimar, o homem de camiseta verde que brinca compulsivamente com uma trena: é desesperador. Benjamin pede para todo mundo se calar, como ninguém obedece decide empunhar a arma e colocá-la na boca de um dos jovens. 
Agora Benjamín se dirige ao homem velho, ele está ajoelhado e é com quem vão negociar. Com a arma na nuca, impossibilitado de olhar para trás, escuta a demanda de Benjamin: dinheiro. Segundo informantes eles têm uma poupança elevada, que agora vão ter que entregar; são 15 milhões de pesos (7.000 USD), uma soma extraordinária para uma família de camponeses. Simón, o pai da família afirma não ter tal dinheiro; em vista da negativa, o homem agressor decide passar a métodos mais radicais persuasão. O pescoço do homem é medido com a trena que o homem de camiseta verde tinha na mão, comunicações secretas entre os agressores indicam uma mudança nos planos. A mulher é agarrada pelos braços e obrigada a sentar no lugar onde antes sentava seu marido, ela obedece. A bolsa preta que era levada com tanto cuidado no início do filme é aberta e vemos um dispositivo inusual: tubos de PVC branco colados na forma de dois U unidos por vários fios de distintas cores. O homem que carregava a bolsa preta, com os gestos de um especialista coloca o dispositivo no pescoço da mulher. Cola as extremidades de cada um dos dois $U$ de modo que formam um quadrado, ou... um colar feito com um tubo PVC. De repente, silêncio!, os agressores foram embora, a família pode se tranquilizar.

André Bazin, célebre crítico de cinema escreveu no ano de 1945 que a fotografia era questão de "fixar artificialmente as aparências corporais do ser. É arrancá-la ao fluxo da duração: apertá-la [l'arrimer] contra a vida" ${ }^{109}$ (Bazin, [1945] 1987, p. 9, tradução minha). É um procedimento no qual algo é retirado da vida para aproximá-lo dela, como que fazendo pressão na vida. O cinema, a imagem em movimento, fase final da fotografia, é "a imagem das coisas e também aquela da sua duração e como que a mania da mudança" ${ }^{110}$ (ibid., p. 14, tradução minha). Claro que para o crítico francês se tratava da objetividade que primeiro a fotografia e depois o cinema trouxeram para o mundo das técnicas de registro e impressão de realidade. Porém o mais interessante desta posição, me parece, está na ideia de que a imagem retira e aproxima. O cinema é questão de contato com a vida, não seria um caminho ou atalho à vida ou à realidade, é a união, da mesma forma que não seria questão de reprodução ou simplesmente réplica, é multiplicação da vida.

109 "Fixer artificiellement les appareances charnelles de l'être. C'est l'arracher au feluve de la durée: l'arrimer a la vie" (Bazin, [1945] 1987, p. 9).

110 "L'image des choses et aussi celle de leur durée et comme la manie du changement" (ibid., p. 14). 
Sobre a fotografia, imagem natural de um mundo do qual não sabíamos ou não podíamos ver, a natureza finalmente faz mais do que imitar a arte: ela imita o artista [...] a existência do objeto fotografado participa, ao contrário, da existência do modelo como uma impressão digital. De modo que ela se acrescenta realmente à criação natural ao invés de a substituir com uma outra $^{111}$ (ibid., p. 13, tradução minha, grifos meus).

Uma alucinação verdadeira, diz Bazin, que não só faz pensar, mas aproxima e revela algo daquilo que é fotografado ou filmado porque se lhe adere, como uma segunda pele em uma junção de sentido. Em outras palavras - e para voltar ao caso específico que me ocupa imagens da violência que mostram e constroem a violência. E que, nessa união de sentido, imagens participam da violência tanto quanto a violência participa da imagem. Parece questão de uma certa identificação entre a coisa feita imagem e o processo de fazer imagens, o que operaria uma aproximação sensível do espectador com esta vida.

\section{O espectador na tela}

O silêncio acalma a família. A mulher, emocionada, avisa da partida dos homens e pede para o homem velho desamarrar os filhos. Ela tem as mãos livres e o ajuda a se liberar das amarras e a se colocar em pé. Os filhos choram e, ao se verem livres dessa tortura, correm para abraçar a mãe e o pai. Todos se perguntam pelo artefato estranho que colocaram no pescoço da mãe, ela tenta acalmá-los. Recorrendo aos métodos caseiros de solucionar os problemas, a mulher pede óleo de cozinha para tentar deslizar o colar pela cabeça e se liberar dele. Diante da ineficácia da tentativa, um surto de medo, choro e preces invade a família. O pai descobre uma fita cassete e pede silêncio para ouvir, é uma gravação/ameaça com instruções: devem entregar o dinheiro em um ponto e em uma hora indicados pelos agressores, por motivo nenhum podem chamar a polícia. De novo, o medo, mas desta vez a fatalidade é real, uma bomba no pescoço da mulher é a forma de obrigar a família de fazer o pagamento da maneira convencionada. O pai desmaia e os filhos pensam

111 "Sur la photographie, image naturelle d'un monde que nous ne savions pas ou ne pouvions voir, la nature enfin fait plus que d'imiter l'art: elle imite l'artiste [...] l'existance de l'objet photographié participe au contraire de l'existance du modèle comme une empreinte digitale. Par là, elle s'ajoute réellement à la création naturelle au lieu de lui en substituer una autre" (ibid., p. 13, grifos meus). 
que ele morreu por causa do choque, mais uma vez a mulher acalma e recompõe os ânimos da família. Restaurada a ordem, elaboram uma estratégia para se livrar do problema: irão à cidade, chamarão a polícia e eles lhes retornarão a tranquilidade. Saem de casa com um rosário na mão.

Entre o momento em que os homens descem do carro até a saída da família da casa, transcorrem aproximadamente 17 minutos. A estrutura circular para descrever o espaço, a relação das personagens e a situação se mantém, assim como o uso de uma câmera muito movimentada nos momentos de tensão e nervosismo. A construção das personagens sedimenta a relação ambígua com o espectador que foi proposta desde o primeiro plano; só no final da agressão os jovens chamam a mulher de mãe e ela chama o homem de pai, sem nomes, sem explicações. Como a ação aconteceu de modo inesperado, não houve tempo de apresentar as novas personagens, porém o espectador estava sendo preparado - mesmo que com um grau de incerteza - para esta cena durante os minutos anteriores. Outro aspecto que chama a atenção nesta sequência é o tempo e a qualidade dos planos dedicados à encenação da tortura: arma no pescoço da mulher e do homem, na boca do jovem, na cabeça da moça, xingamentos horrorosos, empurrões e ameaças constantes. Uma construção que nos faz presentes em um evento que não deve ser visto, nos faz testemunhas de rostos e de eventos que não devem ser conhecidos por ninguém.

$\mathrm{Na}$ sequência do carro, havíamos presenciado um ato similar, quando Benjamín, enraivecido, coloca a arma contra a cabeça do menino. Este fragmento tem uma duração de 2 minutos, começa com o gesto de ameaça de Benjamín no carro e termina com um dos homens protestando pela desordem causada. O plano é aberto e profundo, no primeiro plano vemos o rosto do menino, segue a arma e no fundo Benjamín, nos lados do quadro estão os homens que animam a execução do ato. A câmera está dentro do carro entre o rosto do menino e o homem que está sentado à esquerda, criando uma sensação de presença, como se nós estivéssemos ali no carro, um sexto passageiro presente e cuja possibilidade de ação diante daquilo é negada.

Claro que a presença de armas no cinema não é uma novidade, filmes de assaltos e perseguições animadas por tiroteios foram os primeiros a entreter um público ávido de emoção. Da mesma forma que a tortura e a morte não são mais do que cenas que aceleram o 
ritmo da maioria de filme de ação, film noir, terror ou westerns. Porém, a atenção que reclama a cena antes citada tanto como na cena de ameaça na casa da família agredida surge do tempo dedicado ao ato. Não são cenas construídas em primeiros planos ou em ritmo rápido, pelo contrário, são cenas com enquadramentos mais ou menos abertos e estáveis, a câmera é fixa nestes momentos. Outra coisa que chama a atenção é a obscenidade das imagens - e esta não é uma apreciação moral -, digo obsceno porque são agressões mostradas durante muito tempo, sem que exista intervenção possível, pois a única posição é a de espectador. Aqui há uma exibição escancarada deste sofrimento: como seguir assistindo ao filme? Que tipo de sensibilidade é necessária para assistir estas imagens? Resultará em uma paralisia dos sentidos? Ou, como quer Walter Benjamin, acordaremos do adormecimento confortável pela revelação do espantoso?

O primeiro momento da incursão na casa da família dura 1 minuto e 30 segundos, tempo durante o qual os jovens são arrastados até o centro da casa e o pai é segurado contra um muro. A câmera não enquadra nada em particular, todos são planos gerais dos homens, da gritaria e dos jovens chorando. Neste momento a casa é mostrada, fotos de família e imagens religiosas decoram duas das paredes da casa. Em um segundo momento, que começa quando a mãe é levada à casa, Benjamín exige silêncio, mas ninguém atende suas ordens e quanto mais ele grita, mais choram suas vítimas. No auge desta situação irritante ele introduz sua arma na boca do menino. O plano é mais ou menos amplo, no primeiro plano o pai está olhando para o chão, atrás dele o menino com a arma na boca e no fundo à esquerda a mãe, sentada na cadeira. É quase um instante, dura 14 segundos, no entanto é longo o suficiente para causar um certo ressentimento, é uma imagem-violência, que como explica Rose Hikiji são atos de "violência física que implicam o agressor e a vítima [...] [ao mesmo tempo que são imagens cuja construção provoca] tensão, susto, nojo pelo ritmo ou pelo grotesco [...]. Tema e ao mesmo tempo forma, a violência nestes filmes [o corpus de filmes da pesquisadora] revelava-se como linguagem, no limite, metalinguagem” (1998, p. 68).

Desejo agora estabelecer um contraponto às imagens-violência a partir de outro filme colombiano, Pequeñas voces (2010) dirigido por Jairo Carrillo, uma longa que revela o cruel pela beleza. No press book (2010) do filme é contada a história da criação do filme: este é um projeto que começou em 1999 a partir da ideia do diretor de escutar e registrar as histórias das crianças que vivem em meio ao conflito armado colombiano, com o propósito de entender a violência no país a partir do ponto de vista das crianças - ponto de vista esquecido ou 
marginal nos relatos sobre violência. No ano de 1999, um grupo de desplazados ocupou a sede da cruz vermelha de Bogotá, Carrillo foi ao local com lápis de cores e um gravador de voz para começar o projeto. Depois, o diretor entrevistou 120 crianças, moradoras do bairro altos de cazucá (Ciudad Bolívar, Bogotá), um bairro de periferia que tem influência guerrilheira e aonde chegam numerosos desplazados. A partir deste material, no ano de 2003, Jairo Carillo e sua equipe apresentam um curta-metragem como o mesmo nome. Graças ao sucesso internacional nos diversos festivais dos quais participou o curta se tornou longa e, no ano de 2010, Carrillo estreia o filme, um documentário de animação em 3D.

As crianças, entre 8 e 13 anos de idade, foram entrevistadas e participaram de atividades de desenho, material a partir do qual foi realizada a animação em 3D. O filme narra a história de 4 protagonistas, cada um de diferentes regiões do país, com suas próprias visões e compreensões do mundo no qual vivem e sobre o deslocamento forçado. Contada em flashback, os traços infantis conservam a inocência das personagens, porém a voz é reveladora de situações dramáticas: o Johncito que perde seu amigo durante um treinamento das FARC; o Pepito que perde a perna por causa de uma bomba; a Lulu que perde o pai; e o Juanito cuja família é ameaçada e obrigada a sair do sítio onde moram ${ }^{112}$. Todos se encontram na capital, Bogotá, um lugar sombrio que inspira medo e ao mesmo tempo cria fortes laços de amizade entre eles.

Esta relação entre a forma e o conteúdo, aparentemente contraditória, apresenta uma solução estética e ética de contar uma dimensão desconhecida do conflito armado interno colombiano, que são as crianças, suas percepções, as formas de nomear essa realidade, as pessoas, os problemas e o seu presente. O traço e a voz são destacados e apresentados como caminhos para conhecer a intimidade destas crianças, que falam com grande lucidez do que veem, explicam a violência e mostram o quão estão acostumados a esse estado das coisas. É uma forma de fazer ver uma situação de sofrimento de maneira sensível, que atrai a atenção pela forma sutil e colorida para escutar e entrar em contato com a dor infantil.

A realização deste filme traz para a discussão um ponto importante que pode também ser colocado em relação ao filme de Stathoulopoulos. Nos dois filmes são imagens que

112 No ano de 2003 tive a oportunidade de assistir a curta-metragem. O longa foi exibido na cinemateca brasileira durante o festival de documentário É tudo verdade (São Paulo, 2012) (web site oficial do evento: http://www.etudoverdade.com.br/2012b/home.asp?lng=). Não possuo uma cópia do filme, motivo pelo qual uma análise detalhada se faz impossível, porém o site do filme contém bastantes informações que foram relevantes para construir esta parte do argumento. Disponível em: $\underline{w w w . p e q u e n a s v o c e s . c o m}$. Acessado em $05 / 2012$. 
apelam à experiência de um modo particular pelo uso de diferentes propostas audiovisuais, que causam estranhamento e aproximação, e que podem se colocar diante de uma produção de imagens da violência que fazem da dor um objeto de consternação e consumo. Kleiman (2000) chama esta produção e seus efeitos de "dismay of imagens" [angústia pelas imagens] que alimentam as redes de informação criticadas por Sarlo (2005), mas que, sobretudo, geram no público uma necessidade de explicitar os detalhes escandalosos para autenticar a imagem.

Neste sentido, podem ser estabelecidas comparações entre este filme e La sombra del caminante a partir da construção de um espaço para o espectador. Nos dois filmes existem momentos de aproximação e de distanciamento que fazem com que a visualização dos filmes seja desconfortável. Parece que estamos conhecendo uma estória, a narração de situações da biografia das personagens como em uma conversação íntima, mas, justo no momento em que este contato está sendo consumado, um plano com um olhar (como no primeiro filme) ou um grito (como neste), deslocam e perturbam esta relação. A câmera constrói espaços irreais a partir dos reais (Bogotá) ou fica nervosa quando as personagens têm reações agressivas (Benjamín e a gritaria em diferentes cenas). A intenção de obrigar a ver e permanecer na cena que $P V C$ - 1 mostra, é também uma forma de chamar a audiência a se reconhecer, não como em um espelho e sim com o objetivo de admitir que os agressores não são monstros de mundos desconhecidos, que seus atos não são efeitos de poderes sobrenaturais e que as vítimas não são seres imaginários do mundo dos contos de fadas, mas como um outro que é um conterrâneo, pessoas que em qualquer momento podem estar no mesmo restaurante conosco, que podem curtir de uma tarde de sol em uma praça tranquila ao nosso lado, ainda que não conversemos, ocupamos e construímos o mesmo lugar.

Diante de um tipo de violência que envolve agentes do mesmo mundo local, que até podem se conhecer,

Se faz necessário considerar, como a subjetividade - a experiência interior sentida da pessoa, a que inclui suas posições em um campo de poder relacional - é produzida por meio da experiência da violência e da forma pela qual fluxos globais que implicam imagens, capital, e pessoas se emaranham com lógicas locais na formação da identidade. Nossas noções de formalidade e patologia parecem estar em jogo ao explorar as conexões entre as diferentes formas da violência que permeiam nosso mundo social (Das e Kleinman, 2000, p. I, tradução minha). 
Deste modo, Veena Das e Arthur Kleinman, antropólogos interessados pela relação entre violência e cotidianidade, afirmam a necessidade de observar e realizar trabalhos e etnografias que interroguem a noção de cotidiano e que possam responder à pergunta de como as pessoas vivem uma vida cotidiana reconhecendo vítimas, agressores e testemunhas que convivem no mesmo espaço social. Convivem em um mundo no qual organizações internacionais, mídia e fluxos de capital e pessoas estão implicados na "atualização da violência que transforma o cotidiano das comunidades" (Loc., cit.). Uma proposta que exige ir além das proposições que vinculam causas e consequências de modos automáticos sem observar as condições cotidianas da sua realização. Por exemplo, a afirmação de que a pobreza causa violência não permite entender nem as especificidades da pobreza nem as da violência. E aqui se trata de pensar uma antropologia que seja capaz de fornecer aproximações detalhadas sobre as formas contemporâneas e subjetivas da violência.

Um dos argumentos de Kleinman que resulta instigante para a análise sobre $P V C-1$ é que a "midiatização da violência e do sofrimento cria uma forma de experiência social nãoautêntica: testemunho à distância, um tipo de voyeurismo no qual nada definitivamente está em jogo para o observador" (Kleinman, 2000, p. 232). O pesquisador não especifica o tipo de mediatização que lhe serve de fundamento para a formulação desta afirmação, porém esta indefinição não vai de encontro ao argumento dele, pois expressa claramente a variedade de formas e dinâmicas da apropriação da violência pela mídia, sua presença disseminada nos lugares mais surpreendentes ou inesperados. Nós, ao não termos contato com a violência se não pela narrativa - como afirma Taussig (1986) -, somos afetados/informados/sensibilizados por todo tipo de mediatizações, livros, relatos, filmes de ficção, documentários, televisão ou fotografia, etc. Frente a esta condição, Kleinman afirmam que a forma pela qual a violência é expressada desencadeia um processo que torna o trauma e o sofrimento em mercadoria para o consumo que afeta o tipo de envolvimento do espectador - que ele chama de consumidor visual -, com a própria imagem e com aquilo que a inspirou. Isto é fundamental quando se quer observar as formas pelas quais a imagem constrói a violência (como imagens que se unem ao real) e como tal construção afeta a sensibilidade do público (oferecem leituras, aproximações, convivências com este real).

PVC-1 parece propor uma situação de voyeurismo ao mesmo tempo em que elabora 
uma relação desconfortável. É como se fosse uma das possíveis respostas à pergunta do homem da cadeira em La sombra del caminante: você esta disposto a escutar? Já que Mañe exigiu em outras vezes uma resposta e entristeceu-se pelo silêncio do homem, agora ele obteria todas as respostas. O silêncio, ainda que incômodo, poderia ter sido mais confortável. Porém, Mañe já viveu muitos anos em silêncio, aceitando empurrões, golpes e risadas dos outros, cobranças e pedidos para deixar o local de moradia, e agora que tem o poder de exigir uma resposta não se encolhe ante a situação. $P V C-1$ mostra, não explica, é só presença; responde ao desejo de ver. É uma superfície de imagens onde o espectador depositará todas suas imagens de morte, todos seus medos. Imagens vazias que podem ser preenchidas pela imaginação, mas não qualquer uma, a que é sugerida pela montagem, pelo ritmo do filme.

O longa-metragem recria sensações de medo e de vazio, elabora o tempo de modo que o público é obrigado a ver e não lhe é concedido um segundo para respirar, aproxima a sensação da violência no corpo do personagem à vida do público, oferecendo outras formas de expressão desta sensação. Formas que o diretor utiliza para elaborar em imagens a proposta de fixar na memória um evento cruel. Projeto que ao mesmo tempo suscita reflexões sobre as formas de mostrar a violência, como também provoca questionamentos sobre o que Dawsey identificou, a partir da leitura de Turner, como as formas pelas quais as sociedades "sacaneiam-se a si mesmas, brincando com o perigo"113 (Dawsey, 2007, p. 31). E, se o cinema é uma alucinação real como queria Bazin, não só é uma forma das sociedades se narrarem a si mesmas como é uma forma de brincar com suas próprias estruturas, imagens, símbolos e problemas.

Antes de sair da casa, a mãe pede para o filho mais velho ligar para a tia e contar tudo o que aconteceu e pedir para ela chamar a polícia e denunciar a agressão. Sem dinheiro, o único recurso é o Estado. A família não concorda com o pedido, a voz gravada na fita cassete foi clara nesse ponto: não podem contar a ninguém e muito menos à polícia. Sem escutar motivos, a mãe continua firme na ideia. O homem, sua mulher e as filhas atravessam o sitio,

113 Esta é uma afirmação feita a partir da observação de festas. Sagradas ou profanas são o momento de quebra da ordem. Eu não poderia dar tal importância a um filme, pois as condições da sua visualização e circulação são específicas e diferentes das de uma festa, com consequências e contextos particulares. O que é instigante para pensar o cinema é a ideia da existência de formas para brincar com a ordem, articular elementos, tempos, pessoas, significados que são diferentes, contraditórios, opostos, separados pelo tempo e pelo espaço, em uma sequência de imagens e sons. Isto permite ao cinema construir pela montagem mundos e significados próprios e que ao mesmo tempo têm a possibilidade de deslocar ou iluminar outros. 
chegam na estrada e encontram um vizinho, proprietário de um carro. Não lhe explicam a situação e pedem ajuda para ir até o povoado, ele aceita fazer o favor. Neste momento chega o filho com notícias, o ponto de encontro onde o agente de anti-explosivos desativaria a bomba. Os filhos menores são obrigados a aguardar por eles em casa e pai, mãe e uma filha continuam o trajeto. $O$ vizinho parece perturbado pelas expressões de medo, mas dissimula. Só quando escuta uma pequena menção à bomba requer que saiam do carro. Os três - pai, mãe e filha - começam um trajeto difícil, entre rios e lama até o lugar onde vão encontrar o policial. Depois de caminhar por estas passagens perigosas a família chega ao ponto de encontro, segundos depois chega Jario Hurtado, o especialista da polícia em explosivos. Uma olhada no dispositivo é suficiente para saber que se trata de um aparelho muito perigoso, Jairo volta ao carro que estava dirigindo e pede para sua mulher ir embora com a filha. Ele pega alguns instrumentos de trabalho: o pano do carro, fósforos, uma vela e uma faca de cozinha.

Esta é uma parte do filme que é construída no formato do filme de ação-aventura: obstáculos devem ser superados para que o protagonista chegue até o final do caminho, elementos de tensão e declarações de amor e amizade são pronunciados pelas personagens nos momentos de crise. Voltemos à descrição dos detalhes para mostrar esta estrutura.

Depois de descer do carro do vizinho, caminham longamente através do mato até chegar no trilho do trem, o pai olha para um lado e para o outro, ninguém, então continuam a pé. Alguns segundos depois chegam dois carros, como vagões separados e empurrados por homens que correm ao longo dos quilômetros de trilhos abandonados. Decidem ir em carros separados, ela em um e eles dois no outro. O perigo que ela é para quem a acompanha não é pouco e o desejo é o de não pôr a família em risco. Esta cena dura aproximadamente 1 minuto, só escutamos o barulho das rodas dos carros se deslizando pelos trilhos e o golpe dos pés dos homens que correm contra o solo de pedra e terra. Um giro da câmera para mostrar a paisagem dá a sensação de um plano subjetivo, o público junto à mulher se desloca no carro e observa em silêncio o verde das montanhas em um dia de sol. Quando o movimento panorâmico da câmera termina, a mulher com o olhar para baixo, triste, rezando, ajeitando o colar-bomba que já começa a pesar nos ombros dela. Olhares se encontram, carícias são trocadas. Chegam a outro ponto do caminho, agradecem e descem dos carros. 
Continuam o caminho, a mulher cai no chão, o pai a ajuda a se levantar e se abraçam, ele pede perdão, pois gritou quando ela caiu mas "estas coisas a gente nunca imagina" diz ele. Não há uma resposta, um gesto prescrito para estas situações. O terceiro obstáculo é uma chamada dos agressores que o pai recebe, acalma-os, diz que estão reunindo o dinheiro e que não chamaram a polícia. Finalmente chegam ao rio, a última estação. Ela se senta em uma pedra, a filha fica perto e o pai acende um cigarro, quando de repente um ruído, beep beep que sai do colar-bomba. De novo tudo se tensiona e desorganiza, o descanso é perturbado, os ânimos exaltados. Será uma contagem regressiva? Nesse momento o pai descobre que o lugar de encontro é depois do rio, devem atravessá-lo. Mais provas, mais complicações, um rio não muito profundo, porém perigoso, ela escorrega, de novo lágrimas, gritos e palavras de carinho. Abraçados, chegam à outra beira do rio.

Ainda falta uma grande parte do trajeto para percorrer. Agora sobem uma pequena ladeira, ela exibe sinais de cansaço se apoia na terra, cospe, ajeita o colar-bomba, abraça o marido e continua em silêncio. Chegam em outra estrada de terra, é como se o caminho não tivesse fim, mas devem continuar. $\mathrm{O}$ dia de sol, os sítios, a tranquilidade são o cenário que atravessa esta família desesperada. Agora é a vez de um homem bêbado que canta e se aproxima do grupo, é empurrado, mas se levanta e os segue alguns metros com tanto azar que é empurrado de novo e vai embora, esta não é companhia para sua alegria etílica. Este desencontro termina como um novo beep do colar-bomba, e ela já manifesta desânimo na empresa que começaram. Continuam, não chegam a lugar nenhum, Rosita, a filha que os acompanha, entra em desespero: porque não veem a polícia, será que estão no lugar errado? Será que não vão vir? Mas não há tempo para voltar atrás ou se desviar do caminho! O pai observa com cuidado, e vê o lugar onde vão encontrar a polícia, sinais de alegria nervosa, abraços e beijos recompõem o ânimo da família.

"Subintendente da polícia nacional. Jairo Hurtado, ao seu servico" - Ofelia, - Simón, Rosita $^{114}$, cada um se apresenta. É o começo do final e é o momento em que as personagens que durante 46 minutos acompanhamos se identificam, dizem seu nome.

114 Transcrição do áudio do filme. 


\section{O conhecimento venenoso.}

\section{Imagens da tortura e os limites do mostrável}

Veena Das (2000) estuda o significado de ser testemunha em relação à violência e à formação do sujeito. A antropóloga se pergunta pelas formas de falar sobre a violência fora dos contextos de luto, falas que existem para dar voz, mostrar a ferida e suprir de testemunhas ao prejuízo causado, com o objetivo de fazer com que grupos distintos possam habitar o mundo em união. Neste momento em que a voz emerge, Das atenta que a relação entre voz e visão se articula de modo complexo para expressar um conhecimento insuportável (ibid., p. 207). "Como testemunhar a criminalidade da regra social, que transfere o excepcional do ser ao esquecimento eterno, não por meio de uma transgressão dramática, mas através de uma incorporação à vida cotidiana? ${ }^{115 "}$ (ibid., p. 208, tradução minha). Pois se trata de criar com a linguagem formas de diferenciar as memórias, e não barreiras que as silenciam. E, nesta ordem de ideias, testemunhar, seria uma forma de estar com os outros na qual o "passado entra no presente, não necessariamente como memória traumática, mas como conhecimento venenoso [poisonous knowledge]" (ibid., p. 221).

Dado que para ela o conhecimento pelo intelecto não é suficiente, propõe, então, um conhecimento pelo sofrimento, para que este comece a agir na reparação das relações e no reconhecimento daqueles que a norma oficial tem condenado (ibid., p. 223). Myriam Jimeno (2010), antropóloga colombiana, parte desta ideia de Das e afirma que "a comunicação das experiências de sofrimento - as da violência entre estas - permite criar uma comunidade emocional que alenta a recuperação do sujeito e se torna em um veículo de recomposição cultural e política" (ibid., p. 170, tradução minha, grifos no original). Ela, como Das, critica os modos reducionistas das falas sobre a violência, e procura nas ciências sociais alternativas de falas que deem conta da experiência subjetiva da dor. A partir da análise de Jimeno da proposta de Das, vemos que a ideia de um conhecimento venenoso implica a existência de dimensões da experiência que não podem ser expressadas, nem pela ciência social nem pela arte; o inefável. De modo que existiria o risco de pensar o silêncio como uma opção que seria mais confortável porque impede que o veneno se espalhe.

115 "How does one bear witness to the criminality of societal rule, which consigns the uniqueness of being to eternal forgetfulness, not through an act of dramatic transgression but through a descent into everyday life?" (Das, 2000, p. 208). 
Jimeno segue a argumentação de Das e encontra na leitura que ela faz de Wittgenstein e, sobretudo na frase "minha dor pode residir no corpo do outro" (apud. ibid., p. 174), a sugestão de que há, de fato, formas de expressar a dor: "Das assevera que Wittgenstein proporia a linguagem como a corporificação das palavras, já que, quiçá, ao apontar o lugar onde reside minha dor, encontro o corpo do outro e, pelo menos durante um momento, minha dor pôde habitá-lo" (ibid., p. 173). Para Jimeno, o que interessa desta posição é que a expressão do sofrimento é fundamental na criação de um campo onde se compartilha a dor e se faz possível a identificação com as vítimas, sua recomposição como membros de uma comunidade. Isto coloca em evidência a tensão que existe na narração dos atos de violência (ibid., p. 174), como também coloca a necessidade, o desejo de ocupar-se da violência e de suas consequências.

A ideia de um conhecimento venenoso, não é descartada pela antropóloga colombiana, que pensa no processo contemporâneo de mobilizações de vítimas que exigem conhecer motivações, lugares de sepultamento dos corpos ou reclusão de desaparecidos, nomes dos responsáveis pelas agressões, ser escutadas e reparadas de modo integral. E por este motivo ela se dedica ao estudo da linguagem com a qual se expressam as experiências dolorosas; estas não nascem unicamente do plano íntimo e individual, são configurações sociais, emaranhados de sentido e de formas de contar - e, eu acrescentaria, formatos, veículos de circulação - que dão certeza e desencadeiam processos de escuta e emoção, conhecimento que implica o corpo de quem ouve, lê ou vê tais narrações.

Se referir à violência antepondo a palavra "experiência" procura escorar o enfoque que considera a ação violenta a partir dos sujeitos involucrados, a olhar para ela a partir da sua perspectiva, a colocá-la no terreno da subjetividade. Situar a violência neste campo permite superar algumas dificuldades de método para o estudo da violência, mas especialmente permite resistir ao essencialismo que talvez surge da maneira como utilizamos o termo "violência" na linguagem ordinária e ainda na acadêmica. O termo sugere um fenômeno global que se explica a si mesmo. Induz a esquecer ou silenciar que a violência é uma ação humana, que faz parte do seu repertório de ações e, por isto, é relacional, possui grande capacidade expressiva, e está inserida nas redes de sentido de origem cultural (Jimeno, 2007, p. 182, tradução minha, grifos meus).

Neste artigo de Jimeno, é citada a análise de uma estudante de antropologia, Johana Wahanik, da Universidad Nacional de Colombia (Bogotá) sobre o filme La noche de los lápices, dirigida por Hector Olivera em 1986, para pensar sobre as formas de recuperação da 
memória e projetos de recuperar a fala que podem ser rituais, relato de testemunho ou os da ficção. Claro que o filme que inspirou este capítulo não é uma recuperação de memória, não existe um processo no qual o diretor tenha se relacionado com as pessoas ou apresente o filme como um espaço onde a pessoa que sofreu vai se expressar e se mostrar para propor formas de diálogo e convivência.

A relação entre o filme, a posição de Jimeno e a ideia de conhecimento venenoso de Das, é feita a partir da proposta cinematográfica de fazer sentir o medo alheio pelo uso de um recurso que é o plano-sequência. Pensar a violência a partir das formas audiovisuais, das elaborações possíveis desta experiência e das discussões que suscitam estas elaborações. Portanto, apresentarei os comentários da análise da estudante que são relevantes para pensar a obra de Spiros. Em primeiro lugar, o filme de Olivera seria uma forma de arrancar do esquecimento a história dos jovens presos, torturados e desaparecidos nessa fatídica noite (de los lápices, 16 de setembro de 1976). Em segundo lugar, mostraria esta memória além da verdade jurídica, pois a transformaria em "memória vivencial", a reconstrução "da subjetividade do sujeito histórico desaparecido" (ibid., p. 185). E finalmente, é um "trabalho de recuperação da experiência da violência na linguagem" (ibid., p. 187), ou seja, exigir da linguagem e transformá-la para que a experiência não seja silenciada, porque não é suficiente afirmar que existem dimensões que carecem de expressão, pois isto faz do silêncio algo igualmente venenoso porque retira e impede pessoas de participarem da vida social e cidadã em uma comunidade.

Nervosismo no atuar e ausência de ferramentas profissionais para lidar com um aparelho que parece ser muito perigoso são as esperanças desta mulher. A família é separada e mantida a uma distância segura, contra sua vontade. Jairo começa um processo complicado que consiste em esquentar uma faca e cortar pouco a pouco o tubo, para assim ver o sistema e, idealmente, fazer o que sempre tem feito para desativar um dispositivo explosivo. Preces, gritos, surtos de nervosismo, a presença de mais militares, da cruz vermelha, tentativas de conversa e perguntas irrelevantes acompanham a tensão da operação. Uma vez que Jairo consegue, contra toda expectativa, retirar do colar o que ele chama de "acionador químico" uma sensação de esperança invade as personagens e a tela inteira fica iluminada com um tom de final feliz. Mas, todo final feliz esconde um revés, o 
rosto da dor e da perda, as lágrimas de uma filha que chora a morte da mãe.

"A dona Ofélia não terá uma serreta? Uma lâmina ou alguma coisa. Não trouxeram nada? Como chegaram? E, a dona Ofélia não terá fogo? Isso a gente tira esse negócio com fogo, trouxe fogo? ” São as palavras de Jairo depois de examinar o colar-bomba. Durante os 7 segundos que dura esta fala e uma resposta irônica da mulher, a câmera vai se aproximando das personagens em um movimento panorâmico que os coloca na posição de eixo. De súbito, beep beep, Ofélia dá um pulo e Jairo compreende a situação, a câmera para o movimento e enfoca Jairo, faz um plano à esquerda e quando ele corre até o carro, a câmera se desloca com ele na mesma velocidade. Quando Jairo chega ao carro, olha pela janela do piloto à mulher e à bebê que aguardam desconcertadas, parece que um final de semana de descanso foi arruinado pelo trabalho. Jairo abre o porta-malas, tira algumas coisas e põe no chão dois baldes, um branco e um azul. Nesse momento entra Simón no campo e pergunta pela mulher dele, ao que Jairo responde com palavras formais, típicas de um policial e pede para permanecer no lugar que lhe foi indicado. Jairo pega os baldes, entra no carro reúne no colo, um plástico, um pano vermelho. A mulher pergunta “o que foi?”, mas não obtém resposta.

Ele continua procurando alguma coisa, pega um alicate; ela insiste na pergunta e ele, no silêncio e continua procurando no carro coisas, pega uma caixa de fósforos, um fio de metal e o examina. A mulher está completamente desesperada, ante a atitude muda de Jairo e porque ela vê o desespero do homem frente ao trabalho que vai realizar. Ele olha para ela, para o bebê e pede para ir embora, bem longe! Depois ele coloca as coisas no pano vermelho, pensa e pega um recipiente onde deixou uma faca de cozinha. Ela se queixa e acaricia o bebê, Jairo só insiste no pedido já feito. A câmera está fora do carro, e enquadra esta cena em um plano diagonal fixo. Quando Jairo sai do carro a câmera faz um recuo e ele caminha na frente da objetiva, ele para, dá uma volta, se despede da família. Volta e continua até o lugar onde está Ofelia. A partir deste momento começa uma panorâmica à direita que, de novo, coloca as personagens no centro até chegar a um plano fechado das mãos deles. Neste momento acabam os fósforos que Jairo levou para acender a vela. Ele lembra de ter visto Simón fumando e se levanta para correr até ele e pedir o isqueiro. A câmera então, para o movimento e faz um giro à esquerda, abre o plano e faz um travelling que segue o trajeto de Jairo até o fundo e se detém quando os homens se encontram. Faz um novo giro para se deter nas costas de Jairo e 
fazer um novo travelling até Ofelia. O som é só os ruídos que a manipulação das coisas e os passos fazem, as falas são curtas e pontuais.

Vemos uma correlação entre a primeira cena e esta última, pela forma como a câmera enquadra o espaço. Na primeira cena o espaço estava delimitado pelo carro e a câmera elaborou uma série de movimentos para fechá-lo. Nesta última cena, não existe um espaço com margens físicas, o limite é estabelecido pelos movimentos da câmera, sempre girando ao redor das personagens, colocados assim no centro, a paisagem existe no fundo, mas não faz parte da ação que se desenrola no centro. O fundo vai entrar no campo nos momentos em que Jairo vai até lá ou quando outros policiais se aproximam da cena, mas continua sendo externo, são os curiosos que assistem a ação, Simón e Rosita que choram abraçados, agentes de Cruz Vermelha que atenderam o chamado, militares que chegam depois para apoiar o agente antiexplosivos, e um padre misterioso que observa e condena com um sorriso o sofrimento da mulher. Quando o fundo entra no campo só reforça a presença ausente de um "público", um dos militares se apresenta como o chefe de operações e outro de status menor leva uma garrafa de água para acalmar a sede da mulher. Esta construção de um espaço asfixiante só se diferencia da primeira cena pela criação de um lugar para o público, não somos nem passageiros nem curiosos, só voyeurs.

A diferença das imagens dos jornais de televisão - que são o principal referente neste caso - onde nossa posição é também a de voyeurs, no filme somos questionados sobre este lugar que estamos ocupando. Martín-Barbero ([1987] 1999) se pergunta pela centralidade da televisão em um país que, como a Colômbia, tem a maioria das necessidades básicas insatisfeitas. Sem recorrer ao um fatalismo tecnológico, o pesquisador define a televisão como central no jogo das mediações e da formação do conhecimento e da política. Como ela ocupa um lugar cotidiano, é capaz de integrar vários discursos em um lugar só e ser atrativa para diferentes tipos de audiências. A televisão, afirma Rincón (2000), articula o tradicional, o convencional e o moderno, as transformações e experimentações de linguagem audiovisual, de modo que se atualiza permanentemente no centro das práticas cotidianas. Esta rede produzida a partir do lugar da televisão, de comunicação, cultura e política, unida à sua presença cotidiana, visibiliza os temas, pessoas e situações que pela televisão circulam. Porém, esta seria uma forma paradoxal de fazer visível, porque resulta da "intersecção entre informação e desinformação, verdade e artifício, montagens ritualizadas e espontaneidade" (Martín-Barbero, Op. Cit., p. 81), uma forma de informar desinformando. 
A televisão elabora sua estrutura para que o espectador ocupe seu lugar de forma despreocupada, ao mesmo tempo em que anestesia seu público pela quantidade e velocidade com que emite imagens e sons. Porém à pergunta pela necessidade de realizar um filme deste tipo, com esse ritmo e essa história, não é possível dizer que é com o objetivo de se opor à estética da televisão - pois a utiliza -, mas, é admissível pensar que se trata de exibir a maneira pela qual o sofrimento é comunicado e com isto causar desconforto, e, atuar a favor da discussão sobre a necessidade de fazer conviver o público com estas narrativas pela elaboração de formas de expressar a violência distintas daquelas das redes de informação.

A encenação da violência e esta particular relação que o público mantém com as imagens de sofrimento na sua posição de voyeurs, é discutida em vários filmes pelo realizador austríaco Michael Haneke. A respeito do filme de 1992, Benny's video, Hikiji afirma que, "[o]s minutos longos, quase irritantes, funcionam como dispositivo reflexivo. A ausência de sentimentos na expressão do protagonista, que limpa o crime como quem lava a louça, reforça o distanciamento do espectador. Não há com quem se identificar. Não há justificativa para aquela violência" (Hikiji, 1998, p. 117). A pesquisadora responde à proposta de Haneke de criar espaços fílmicos onde o espectador seja impedido de consumir as imagens de violência, porque lhe seria oferecida uma forma de sentir e pensar junto à personagem. $\mathrm{O}$ sofrimento das vítimas e a não-identificação do agressor permitem que a audiência tenha um "espaço para pensar" (Mattias, 2003), porque o que se mostra não é o ato de violência em si, mas o que acontece ao redor dele: reações das outras personagens, a câmera que não se mobiliza pelo som de um tiro ou um grito, o tempo que dura a morte, o peso do corpo do morto, o sangue que suja o chão.

Haneke, em sua filmografia, tem procurado refletir sobre as formas que o cinema utiliza para mostrar a violência. Em oposição aos filmes de ação em que a morte é um instante banal da cena, em que corpos são agredidos, cortados e torturados, filmes que satisfazem o desejo de ver a dor, o explicam e o justificam, o diretor oferece imagens cuja visualização é tortuosa. Tal é o caso de Funny games (1997), no qual uma família que vai ao campo passar uns dias de férias é torturada pelo simples prazer dos jovens assassinos de executar atos violentos, de modo planejado e com uma duração prescrita. Neste filme, o público é tornado cúmplice pelo simples fato de assistir ao filme e parece decidir os tipos de agressão a serem realizados nos corpos das vítimas, durante os quase 100 minutos que dura o longa-metragem; o lugar do espectador é deslocado e este é obrigado a estar presente em um lugar que, normalmente, não 
deseja estar: na sala de tortura e não como vítima ou agressor, mas como coordenador da cena a quem se espera saciar de prazer visual pelas imagens de violência. Só que não vemos nada e somos confrontados com nosso próprio desejo de ver.

Em outro filme, chamado Le setième continent (1989), o diretor mostra um ato de suicídio sem a espetaculização ou dramatização com que um ato destes pode ser encenado. A sequência de abertura é composta por planos de partes do corpo dos membros de uma família burguesa em uma rotina matinal: alarme às 6 da manhã, pés nas pantufas, mão pega a saída de banho, mãe acorda a filha, mão pega a escova de dentes, mãe prepara café, família toma café da manhã. Outras imagens mostram mais do cotidiano, informações do trabalho do Georg, o pai, problemas na escola de Georgie, a filha, rotinas de Anna, a mãe. E finalmente uma longa sequência final de destruição: a família decidiu fechar as portas de casa, acabar com a propriedade e morrer, tudo isto em planos que não se diferenciam dos primeiros. Não há emoção, operam movimentos mecânicos, quebram discos, jogam o dinheiro fora, rasgam livros, tomam pastilhas e morre a filha, a mulher e finalmente o homem; tudo de forma trivial. O ritmo não é alterado durante o transcurso do filme e não somos preparados para este final, nada é explicado e o ato suicida cobra uma força significativa importante, não é trágico nem ligeiro, é um ato cuidadoso e metodicamente preparado. Haneke explora assim, as formas de criação de suspense ao redor da morte para refletir acerca do tempo e as formas de justificar/explicar a morte no cinema.

Sem discursos heroicos nem grandes reflexões sobre o que é morrer, sem primeiros planos do sofrimento nos últimos segundos de vida, do medo à morte ou da perda dos parentes e pessoas queridas, o filme de Haneke nos obriga a pensar sobre as expectativas que temos em relação à morte em imagens. Ele esvazia de sentido o ato, de forma lenta e contínua, nos obriga a ver a operação que ele realiza nessa imagem, não temos opção de sair daquela casa nem, de não ver a morte destas pessoas com as quais não temos nenhuma relação, mas cuja morte nos é oferecida sem pudor. De novo, somos público de um evento de morte, só que aqui não se trata da agressão e sim da dimensão definitiva da morte, mesmo que seja no cinema: como dizia Bazin, "na tela o toureiro morre todas as tardes" (Bazin, 1951 apud. Xavier, [1983] 2008, p. 134).

Esses são filmes que refletem sobre o tempo e a morte. Por meio de uma montagem que elabora uma duração longa do momento da morte e põe em contato com o corpo do morto, 
esses filmes pensam as maneiras que têm sido privilegiadas para encenar este tema. $P V C-1$ põe em contato o medo frente à ameaça de morte, Benny's video alarga as cenas dedicadas à manipulação do corpo da pessoa assassinada, Funny games mostra, não mostrando, a tortura e crítica o espectador que se satisfaz vendo a violência na tela e Le setième continent crítica as formas pelas quais a morte é mostrada e justificada como espetáculo. Cada uma na sua forma específica contribui para pensar os limites do mostrável. Se a audiência já está anestesiada pelas imagens da violência na(s) tela(s), como subverter este estado, com mais crueldade nas imagens? Menos? Não mostrar? Ou, elaborar essas margens para alargar os significados e as imagens relativas à morte violenta?

\section{Rewind.}

\section{Reflexão sobre o tempo nervoso}

"aguarde aqui minha senhora, um segundinho" diz Jairo - "um segundinho? Um segundinho?! Um segundinho, que me dê um segundinho! Como se eu tivesse segundos a mais, eu não tenho segundos, sabe? Eu não tenho segundos para ninguém! Esses desgraçados os tragaram todos, eu não tenho segundos!", diz Ofelia em um acesso de loucura e desespero - “tranquila!”, pede um dos policiais - “eu não tenho segundos!”, repete ela gritando "para ninguém!” grita mais alto.

O som diz mais pela ausência que pela presença, pois se o filme está construído em um formato de ação-aventura são os silêncios entre diálogos, gritos e choros, que aceleram o ritmo e indicam a emoção a ser sentida. As falas das personagens são gestos e não aportam informação. Ofelia pergunta pela mulher de Jairo, ela quer saber como se conheceram, ele se recusa a responder, diz que contará a história completa quando terminar o trabalho, tanto a pergunta como a resposta não são significativos nesse momento, é o fato de perguntar, a vontade de tornar o momento mais amável. O trabalho, dificultado pela falta de ferramentas profissionais, fazem com que Jairo demore muito tempo na desativação da bomba, tempo que é ocupado com novas tentativas de conversar sobre a cotidianidade, um pequeno momento de alucinação de Ofelia sobre o que significaria sua ausência para os filhos, o pedido de água e a 
ida para um muro afastado para que ela possa urinar e os cumprimentos dos militares. Dentre estas falas a mais relevante é a citada acima, quando ela afirma desesperada que acabou seu tempo, uma enunciação do que seu corpo está sentido.

Palavras que corporificam as sensações, um tempo que não é o que conhecemos (do relógio), este filme está elaborado na chave de um tempo nervoso.

Michael Taussig (1995) se ocupa da relação entre ordem e desordem, em um estudo do sistema nervoso no qual se dedica a estudar as formas pelas quais a ordem é restabelecida em rituais ou pelo uso da magia, e, sobretudo, pela escrita disciplinada das ciências sociais. Aqui o antropólogo observa assuntos como o da violência, a criação de símbolos nacionais, a medicina e a narrativa da enfermidade, o fetiche da mercadoria e a arte. Conceitos como os de regra, exceção, arbitrário e sistema são elaborados ao longo do texto para entender, por um lado, como o arbitrário conforma o sistema (ibid., p. 197), e por outro lado, ver como o fato de "o nervosismo do sistema nervoso [ter] sido utilizado contra si mesmo. Foram desmantelados os significantes, a linguagem tem se tornado som, e em todos os lugares jaz a paisagem petrificada e primitiva da Segunda Guerra Mundial” (ibid., p. 198). Duas ideias que ao serem aplicadas à análise da violência, esclarecem o tipo de uso que dela faz o Estado e as configurações que esta tem nos mundos do cotidiano e das artes.

No Estado, a união entre violência e razão, “[...] torna a violência em uma ameaça porque a imbui da maior força de legitimação que existe, a própria razão. Não só porque torna a razão em algo ameaçador, ao indicar como ela tem se ajeitado profundamente dentro da cova do terror, mas também porque necessitamos desesperadamente acreditar na razão, assim como ela está instituída, como a defesa contra a anomalia aterradora e o caos que aperta de todos os lados" (ibid., p. 149). A noção coisificada de violência a torna um fim em si mesma (ibid., p. 150). Já nas artes, é possível a realização da cópia falsa, um esforço que cria dilemas para a representação, pois o signo (no sentido de Saussure) não atua como um fechamento totalizador, e "encontramos um mundo móvel onde os significados, ou pelo menos as referências são tão fixas quanto na mudança [...]". E podem aparecer cópias que o são e cópias que não o são (ibid., p. 224), sendo que o que importa não é que a cópia seja cópia fiel, mas que seja apresentada como tal.

Taussig se interessa pela ordem que é desordem, sistemas que têm como fundamento o arbitrário cujo movimento não é o de uma busca de soluções para a desordem, para restaurar a 
ordem e sim o de manter a desordem ativa, pois é ela que sustenta esse sistema racional e organizado. Ou, nas palavras lúcidas de Benjamin: "a tradição dos oprimidos nos ensina que o “estado de exceção" em que vivemos é na verdade a regra geral” (Benjamin, [1940] 2010). A pergunta que Taussig faz aqui é a de como falar sobre o terror na antropologia, qual distância é a correta para que o terror não se volte contra nós e para que nós não o compreendamos como uma realidade asséptica. E como não existe uma resposta simples ao problema, o caminho que segue o antropólogo é o de explorar as formas de falar sobre o terror: o terror como sendo cotidiano, justificado pela estrutura da sociedade; ou como uma desordem ordenada, desvio da norma; ou o erótico da vigilância que assegura a normalidade do terror; o silêncio que nega o visível, onde o que não é dito adquire sentido, pois os fatos seriam conhecidos, mas prisioneiros da memória privada a qual lhe é negada a expressão; a contradição entre a palavra oficial e a individual que cria paranoicos; ou, enfim, a loucura do cotidiano, um estado de irrealidade no qual nem se suspeita que o terror seja presente. Um artigo sem conclusões que quer provocar nos leitores reflexões sobre as palavras (as decisões) selecionadas para escrever, falar ou nomear o terror. E, quiçá, alterar o estado do sistema nervoso para que escrever, escutar ou ver, o terror seja uma tarefa difícil, incômoda e necessária.

O sistema nervoso pôde "enganar e confundir no coração da mimesis, contudo a mimesis está no coração do mundo, suas manifestações, seus infortúnios, suas curas" (Taussig, 1995, p. 223). O que quer dizer que nós falamos com as mesmas palavras que esse sistema nos oferece, o desafio está em utilizar estes recursos para mobilizar as representações, jogar a desordem contra ela mesma. Aqui, o poder da imagem como "material corpóreo capaz de despertar a memória, estimular momentos de sonhos coletivos [...]” (ibid., p. 22) e a montagem como um lugar onde "a teoria social e a prática cultural entrecruzam-se de tal maneira, que surge uma diminuta oportunidade de "redimir" o objeto, lhe oferecendo uma possibilidade de transpassar os conceitos que o aprisionam e de influir na vida mesma" (ibid., p. 19), são elementos chave da análise, que têm o poder de perturbar, desconsertar, propor uma tensão criativa que impediria adormecer, para provocar visões e reações diferentes das que a autoridade e a razão oferecem.

O tempo nervoso que proponho aqui é uma lente para ver o filme de Spiros 
Stathoulopoulos: um filme tenso que é uma ordem planejada até nos mínimos detalhes que contém e constrói a violência. Tempo em plano-sequência, mimesis falsa e ameaça à vida. Nervoso, ressonância dos gritos, do choro, do medo e do desespero que é capaz de alterar até a estabilidade da câmera e com isso nossa posição diante do filme. Uma estrutura circular que apesar de voltar ao plano inicial de cada movimento, como se fosse um fechamento, não termina, pois começa de novo em outro lugar e só a explosão é capaz de marcar o segundo final. 
Considerações finais

\author{
Aftermath \\ (balanço, ponderação, sequela...)
}



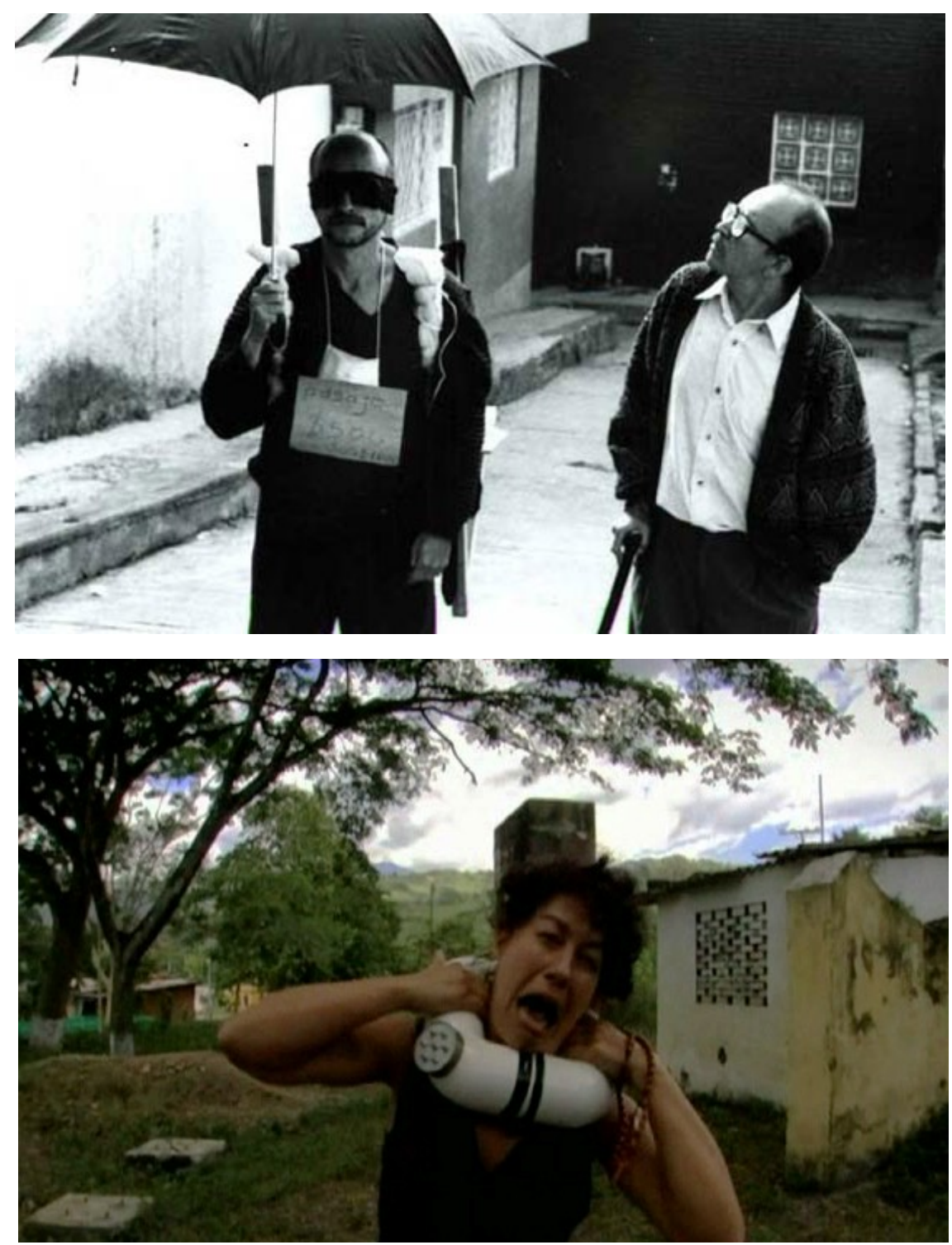

“ [...] o que me agrada extraordinariamente no cinema são as articulações poéticas, a lógica da poesia. Parecem-me perfeitamente adequadas ao potencial do cinema enquanto a mais verdadeira e poética das formas de arte. Estou por certo muito mais a vontade com elas do que com a dramaturgia tradicional, que une imagens através de um desenvolvimento linear e rigidamente lógico do enredo.

Esta forma exageradamente correta de ligar os acontecimentos geralmente faz com que os mesmos sejam forçados a se ajustar arbitrariamente a uma sequência, obedecendo a uma determinada noção abstrata de ordem. E, mesmo quando não é isso o que acontece, mesmo quando o enredo é determinado pelos personagens, constata-se que a lógica das ligações fundamenta-se numa interpretação simplista da complexidade da existência.

O material cinematográfico, porém pode ser combinado de outra forma, cuja característica principal é permitir que se exponha a lógica de pensamento de uma pessoa. Este é o fundamento lógico que irá determinar a sequência dos acontecimentos e a montagem, que os transforma num todo" (Tarkosvki, 1998, p. 17). 
O filme como experiência, melhor, como expressão de uma experiência que tem a capacidade de articular história, imaginação, fotografia, formas fílmicas, tempo, voz, música e narrações. Forma técnica e poética, enraizada no contexto do qual surge, porém, não limitada a ele. Cujos atributos autorizam posicioná-lo ao lado de outras expressões, em outros formatos, realizados em contextos temporais e espaciais distintos e, com isto, gerar sentido, pois esta é sua natureza: a montagem. Sobretudo, capaz de fazer surgir sentidos subversivos, deslocados e raros até absurdos que se relacionam por harmonia ou fricção com outros sentidos e exigem um olhar detido e crítico no mundo, nas suas diversas dimensões e manifestações.

Esta dissertação é um esforço de reconhecer o valor e o lugar das produções cinematográficas colombianas - sem que o tema se restrinja à geografia -, na construção de uma narrativa da violência política e do conflito armado. Em outras palavras, esse texto é resultado da reflexão sobre as formas pelas quais a sociedade colombiana se narra; como constrói o presente, articulando-se ao passado e concebendo um futuro a partir do reconhecimento das experiências de dor e sofrimento vividas por seus cidadãos. Pretendi, neste momento, estudar a possibilidade de contar o terror subvertendo-o (como propõe Taussig (1986), inspirado no chamado de Walter Benjamin por uma forma diferente de historiografia), isto é, entender como certas manifestações artísticas são formas de negociar com o mundo, elaborar comportamentos e sentimentos para lidar com a realidade, com seus problemas e angústias, para estabelecer espaços coletivos de fala, escuta e convivência.

A opção pela cinematografia justifica-se tanto por vivências pessoais quanto por trabalhos teóricos anteriores. Sendo membro fundador da Corporación Cultural El Barco, na cidade de Bogotá, no ano de 2004, participei durante cinco anos de debates sobre cinema, já que esta é a atividade principal do grupo. Três dias por semana, na Biblioteca Pública Virgilio Barco (localizada em uma região que é ponto de cruzamento de bairros residenciais, industriais e setores estudantis da cidade), El Barco apresentava uma seleção de filmes e temas que eram discutidos com a plateia. Durante os debates, surpreendiam as maneiras pelas quais as pessoas relacionavam o filme com sua vida privada e com o contexto político do país, independentemente da nacionalidade do filme, as pessoas sempre teciam comentários sobre suas realidades. Muitos destes comentários refletiam, pelo deslocamento dos termos, sobre o 
mundo colombiano: na tela assistimos a formas inusitadas de resolver problemas e lidar com o passado, rimos das personagens e das situações cômicas, choramos com as tragédias e, principalmente, vimos/escutamos histórias. Neste espaço nasceu a interrogação pelo cinema, o porquê destas respostas ao filme, quando muitas das vezes não havia na imagem nada que o relacionasse diretamente com as "questões nacionais" ou com o mundo cotidiano. Mas também, impressionava-me que as respostas ao filme instigavam narrações de histórias pessoais, de poemas, de fragmentos de novelas e até de notícias. E assim, durante o debate, criávamos outras histórias, fazíamos montagens de memórias, reportagens escritas e televisivas, música, literatura e cinema.

O primeiro exercício de sistematização teórica das experiências e observações desenvolvidas com El Barco foi realizado na elaboração do trabalho de conclusão de curso de graduação em Antropologia, em 2008. Nessa oportunidade, refleti sobre a relação entre as "histórias de vida" na televisão, a categoria de vítima e o momento político na Colômbia nesse momento em que se desenvolvia o processo de Justiça e Paz (lei 975 de 2005). Dediquei-me, então, a pensar a forma pela qual o sujeito político identificado como vítima estava sendo configurado pelas campanhas de comunicação e difusão da citada lei, particularmente em um programa de televisão produzido pela Procuraduría General de la Nación - PGN (órgão que no Brasil é equivalente ao Ministério Público Federal) com apoio de uma empresa privada, a Karamelo Producciones, que funciona sob a direção de Alexandra Cardona $^{116}$.

Tiempo de la verdad ${ }^{117}$ era o nome do programa de televisão que chamou minha atenção em 2008. A série foi curta, num total de dez episódios apresentados nos canais de televisão pública colombiana, estes capítulos foram precedidos por 10 curtas-metragens que passaram massivamente pela televisão nacional, canais públicos e privados, com o intuito de publicizar a série e a lei. O que me interessou não foi o resultado e sim a proposta audiovisual desenhada pela equipe da produtora. A qual se consistiu de um trabalho preliminar de aprendizagem dos detalhes da lei, depois, em reunião com a antropóloga Gloria Elena Henao ${ }^{118}$ e o jornalista

116 Alexandra Cardona é "roteirista, escritora, produtora, diretora e sonhadora", como descreve sua atuação profissional no site da produtora (www.karameloproducciones.com). Foi roteirista do filme Confesión a Laura, dirigido por Jaime Osório no ano de 1991.

117 Os capítulos da série estão disponíveis no web site da produtora: http://karameloproducciones.com/index.phpoption $=$ com_content\&view $=$ article\&id=95\&Itemid=109\&lang =en. Acessado em 08/2012.

118 Gloria Elena Henao é a atual decana da faculdade de Ciências Sociais, Básicas e Humanas do Politecnico Colombiano Jaime Isaza Cadavid, na cidade de Bogotá. 
Hernando Salazar ${ }^{119}$ foram discutidos os alinhamentos éticos e estéticos para a série. Após este período de preparação, a equipe visitava as pessoas nos seus lugares de moradia. Vítimas de diversos ataques perpetrados por grupos paramilitares em distintas regiões do país, estas pessoas falavam durante horas à câmera, algumas reconstruíram a cena, outras mostraram fotografias e suas casas, outras, enfim, criticavam o processo e colocavam perguntas ao governo.

As horas de filmagem eram editadas em Bogotá, no estúdio da produtora. Com muito cuidado porque era um "conteúdo muito difícil [...] deve ser muito bem manipulado, delicada, pontualmente manipulado", como afirmou a diretora ${ }^{120}$ e com o objetivo de sair da estética institucional que torna estes relatos tele-audiovisuais ${ }^{121}$ tediosos. Os eixos da série foram três: a) quem são as vítimas, b) quais são seus direitos e c) como podem exercê-los. Assim, depois das "histórias de vida", como foram chamados os testemunhos pela equipe de produção, abria-se à discussão, ao vivo, com convidados especialistas na lei. Perguntas realizadas pelas próprias vítimas, pelo jornalista-apresentador do programa, Ernesto McCausland e pelos telespectadores que entravam em contato pelo telefone ou chat. $\mathrm{O}$ programa terminava com uma animação dos passos a seguir para entrar no processo de reconhecimento e reparação que a lei tinha inaugurado.

Era, pois, uma forma de mediação entre as vítimas, o Estado e a sociedade civil. Uma maneira audiovisual de entrar em contato com histórias que ainda não haviam sido escutadas com o devido cuidado. E, sobretudo, um meio pelo qual as vítimas reclamavam atenção, solidariedade, reconhecimento e olhares críticos, sensíveis, de todos na sociedade colombiana. Como uma das entrevistadas afirmou em um dos capítulos:

Vocês tem tido hoje a oportunidade de ver os rostos das famílias dos desaparecidos do CTI [Corpo Técnico de Informação] mas, eu quero lhes mostrar [levanta uma fotografia]: esta foi minha família até o dia em que levaram meu marido, com seus companheiros. Assim, como meus filhos e os filhos de muitas famílias tem sofrido o da violência. Não permitam que continuem enterrando as verdades na Colômbia, porque assim como nós, vocês têm sua própria família. É uma mensagem para refletirmos todos, é uma obrigação tanto sua como nossa entregar a estas crianças [assinala a fotografia] e

119 Hernando Salazar é o atual diretor de comunicaçoes na Alta Consejería Presidencial para la Reintegración.

120 Entrevista com Alexandra Cardona, realizada no dia 9 de maio de 2008 no escritório da produtora Karamelo Producciones.

121 Nome que dei aos testemunhos desta série na comunicação apresentada no ano de 2011 em Buenos Aires no congresso X CAAS. Texto completo disponível em http://xcaas.org.ar/grupostrabajosesiones.php? eventoGrupoTrabajoCodigoSeleccionado=GT52. Acessado em 05/2012. 
a milhares de crianças na Colômbia as verdades do que aconteceu com cada um dos membros das famílias que tem sofrido com a violência nesse país (Claudia Ballesteros, episodio 8 ¿Dónde están los muchachos del CTI?).

Embora tenha sido um estudo curto (já que se tratava de uma monografia), foi possível explorar as questões da imagem, a construção de sujeitos políticos e de "verdades nacionais" e elaborar, ainda que timidamente, perguntas a partir da teoria antropológica que lida com narrativa, dimensões do cotidiano, formas de conhecer e de escrever. Neste trabalho entendi que a vítima começava a se constituir como sujeito político, não só pela sua transformação em figura jurídica - em um artigo de lei - mas, principalmente, pela apropriação da categoria por pessoas que elaboravam um espaço e um tempo onde podiam habitar, falar, reclamar, criticar e dirigir os olhares e sentimentos da sociedade a elas e suas experiências. Entendi, sobretudo, que a imagem era poderosa porque deslocava e desarticulava imaginários oficiais, obrigava $o$ espectador a apertar o botão de pausa, para respirar e ver o mundo em ralenti. O tempo é fundamental, por exemplo, em um dos comerciais promocionais da série em questão uma voz pedia tempo, exigia que o espectador se detivesse durante uns minutos para ver e ouvir.

Algumas das questões suscitadas por esse trabalho de graduação se desdobraram e estão contidas na presente dissertação de mestrado onde me perguntei qual é a experiência que o filme oferece, especialmente quando é um filme sobre violência e sofrimento. O filme de Ciro Guerra, conforme analisei no primeiro capítulo, não segue o ritmo da cidade, acompanha o ritmo vagaroso do andar das personagens pela cidade e pelas biografias de cada um, contadas em desordem e aos poucos. Já o filme de Spiros Stathoulopoulos, como foi considerado no segundo capítulo, condensa o tempo e com isto consegue criar um momento onde a sensação do sofrimento é vivida, embora o sofrimento seja o alheio. Tempo que, talvez, abra espaço para um lugar diferente, outras configurações destas categorias fundamentais.

Taussig (1986) comenta as mediações por meio das quais conhecemos o terror, possivelmente os dados sejam públicos assim como as datas, o número de mortos, as consequências econômicas e políticas; mas, a dimensão íntima da dor e do sofrimento permanece escondida pela superfície cheia de informações factuais. A narrativa nos aproxima da dor alheia, nos faz, por uns instantes, conhecê-la. A imagem, diz Bazin ([1945] 1987), subtrai fragmentos da realidade e os cola à realidade, não a replica, a multiplica e a constrói. O cinema, então, nos oferece imagem, som e tempo, a vida dos outros, as narrações de vozes 
longínquas, os olhares expressivos de quem não conhecemos, as narrativas de um sofrimento que nem imaginamos. Ao mesmo tempo, fixa, é documento e é monumento, é discurso. Imagem e som, arte audiovisual que condensa fragmentos de vida e os torna objeto, prazer como também desconforto audiovisual - como a série e os filmes analisados - pois são imagens em movimento que contam tragédias vividas por pessoas não muito diferentes do espectador, moradores de lugares que este provavelmente conheça e que apenas começam a desvendar um passado-presente doloroso.

Edward Bruner (1986) chama a atenção para as expressões da experiência (aquelas formas em que a experiência é concretizada) e problematiza a relação entre realidadeexperiência- expressão e compreensão. Para o antropólogo, a "experiência estrutura as expressões [...] Mas, as expressões também estruturam a experiência, as narrativas dominantes de uma era histórica, rituais importantes e festivais e obras clássicas de arte definem e iluminam a experiência interior" (ibid., p. 6). É uma relação de construção conjunta onde todas as partes se encontram e se alimentam, de modo que não existe uma obra definitiva nem uma experiência acabada, estas seriam produtos históricos e culturais em permanente construção.

A função principal das expressões é, pois, fornecer ferramentas para o entendimento da realidade. Sua estrutura objetiva, com princípio e fim, permite que sejam identificadas e apreendidas por diversas pessoas em tempos diferentes. Inclusive pelo antropólogo que queira se aproximar de um grupo, de sociedades distintas da sua, ou, como neste trabalho, com dimensões díspares da própria sociedade, do mundo de vida da pesquisadora. A arte seria um portal para o estudo das dimensões da vida que não são quantificáveis ou delimitadas por regras ou textos, que permite distância e, ao mesmo tempo, a inserção no desconhecido e indica a capacidade interpretativa de quem observa. As nossas produções teóricas são, em parte, interpretações de interpretações, afirma Bruner (ibid.), e com isto assevera a riqueza que se encontra na arte e a necessidade de mediações e participações coletivas na produção das teorias.

Rituais, danças, manifestações políticas, narrações são fontes de conhecimento sobre o outro. Já as imagens fotográficas ou de cinema ocupam um lugar diferente, ainda que batizado de sétima arte, o cinema não conheceu tal atenção por parte da antropologia. A câmera foi empregada do mesmo modo que a caneta, e isto não sem problemas, como afirma Caiuby 
Novaes $(2004,2009)$. Quando o cinema de ficção foi objeto de estudo, este cumpriu a função de "olho à distância" e não de expressão, elaboração da experiência. Ou seja, não foi compreendida a particularidade da criação audiovisual, suas qualidades plásticas e seu princípio estruturador da montagem. Outros estudos mais contemporâneos (Hikiji, 1998; Da Cunha, 1999 e 2004; Barbosa, 2002; entre outros) observam as múltiplas dimensões do cinema e pensam-no como uma forma de interpretar e construir a realidade. Este trabalho inspirou-se nesses debates e propostas com a finalidade de analisar o cinema, pensando-o por meio da teoria antropológica, para refletir sobre a ideia de o cinema ser um lugar onde elaboram-se narrativas do terror.

Os livros de guerra que inundaram o mercado literário nos dez anos seguintes não continham experiências transmissíveis de boca em boca. Não, o fenômeno não é estranho. Porque nunca houve experiências mais radicalmente desmoralizadas que a experiência estratégica pela guerra das trincheiras, a experiência econômica pela inflação, a experiência do corpo pela fome, a experiência moral pelos governantes (Benjamin, 1933, p. 115).

O problema colocado neste contexto é possibilidade assim como a impossibilidade de contar, e nossas responsabilidades como pesquisadoras em ouvir, aprender e relatar. Trata-se da busca de lugares, dinâmicas, estratégias, formatos, onde a enunciação da dor seja possível, onde a escuta e a construção de narrativas coletivas sejam propostas. Uribe (2005) afirma que é também uma busca por um processo de apropriação - por pesquisadores, artistas, jornalistas ou juízes - destes relatos no qual as vítimas que oferecem seus relatos não percam o controle e a autoridade sobre estes, pois, como alerta a antropóloga, isto seria pior do que silenciá-las.

Nessa pesquisa, entendo que entre a narração como forma possível de transmitir experiência (Benjamin [1936] 2010) e narração do terror para subvertê-lo (Taussig 1986) configura-se um campo de estudos onde o cinema se mostra como um objeto rico em propostas e problemas. Um filme é lugar de encontro e ponto de cruzamento, onde se faz possível o diálogo entre os mais variados elementos e se apresenta a necessidade de relacionar materiais de formas diversas das binárias, lineares ou arquetípicas. É também um processo que permite a apropriação do tradicional para transformá-lo, como acontece no filme $P V C-1$. $\mathrm{E}$, assim, elabora críticas à própria forma de produzir imagens, de distribuir sua organização e compreensão a serviço da informação e do consumo. Spiros retira uma imagem do fluxo das 
notícias que, na época, foi útil para criticar o governo, para refletir sobre a pessoa e seu medo além do seu significado prático e valor instrumental. Ou, como em La sombra del caminante, onde o senso comum é questionado ao apresentar outras dimensões de quem durante anos foi colocado no campo semântico do mal sem maiores discussões. Neste filme de Guerra a criação de personagens ambíguas questiona exatamente esta classificação rígida de "bem" e "mal" e compromete o espectador na reflexão sobre a construção destas categorias que tem servido tão bem à simplificação do entendimento da violência na Colômbia.

O objetivo desta dissertação é entender como a imagem fílmica propõe não só um tipo de narrativa da sociedade sobre si mesma, mas elabora formas de contar e de vivenciar a experiência do terror. A partir do trabalho realizado no primeiro capítulo em torno deste objetivo, surgiram questões sobre o uso da categoria de invisibilidade, utilizada para descrever tanto a forma de presença do homem da cadeira no filme de Ciro Guerra como uma particular posição na sociedade bogotana dos desplazados que chegam à cidade por causa da violência rural. Ainda sobre o filme de Guerra, a questão da desfiguração, entendida a partir de Taussig (1999), trouxe alguns problemas em relação ao segredo e à vontade de revelação que se encontraria no trabalho de desfiguração. Outro ponto que se tornou visível e de urgente atenção, mas sobre o qual apenas farei alguns apontamentos em breve, foi o apelo à inenarrabilidade do problema, pois esta seria uma forma de esconder o problema distanciando-se dele, recobrindo-o com um véu de inapreensibilidade, quando a tarefa é a oposta: dar forma pela imagem ou pelo texto ao que foge à compreensão para fazê-lo existir, torná-lo evento, inseri-lo na história, na biografia, nas narrativas nacionais, na agenda de problemas antropológicos que pretendem entender uma situação de violência na chave da experiência cotidiana.

A análise do filme, na primeira parte deste trabalho seguiu principalmente três eixos: as estratégias do filme para interpelar o expectador, o olhar como vetor e a instabilidade (improvável e plausível) da narrativa e de suas personagens. Uma estratégia que organizou a compreensão do filme e não permitiu estabelecer uma relação confortável com a imagem, pois a cada sequência novas perguntas eram colocadas e os eixos iam complexificando-se até desencadear em uma série de associações (a mais importante é aquela feita entre o filme e os testemunhos audiovisuais citados acima). Neste encontro, a questão da invisibilidade se coloca de forma interessante: pois um filme, ou qualquer tipo de imagem, é uma forma de fazer visível. O homem da cadeira, assim como Mañe, são formas que tornam visível a 
invisibilidade de pessoas que habitam nas margens da cidade: aqueles que fazem trabalhos informais, os que deambulam pelas ruas, as pessoas que pedem esmolas, os desplazados. Eles seriam invisíveis, não porque ninguém os percebe fisicamente, mas porque eles (seus mundos, seus corpos, seus problemas, biografias e linguagens) não são possíveis interlocutores.

Podemos afirmar, a partir do primeiro capítulo, que as personagens são alegorias da violência. Alegorias da invisibilidade dos sujeitos criados como objetos impossíveis da política e da visão pelas dinâmicas de violência (Feldman, [1997] 2000, p. 49). O termo alegoria sugere uma "esquematização que realça relações, repete para sublinhar pontoschave" (Xavier, 1993, p. 37) de modo que "cada figura condensa atributos variados, encarnando numa unidade singular um conjunto de segmentos da sociedade, uma convergência de posição política e inclinação psicológica” (ibid., p. 54). Então, as personagens de La sombra del caminante chamam à atenção para o que Castillejo (2000) identificou como o não-encontro do desplazado com o resto da sociedade. E este poderia ser o ponto de partida para a construção do reconhecimento e de uma narrativa comum, onde as vítimas e a sociedade encontrem-se e construam-se como parte do mesmo tempo e espaço ${ }^{122}$.

Uma vez que no capítulo sobre La sombra del caminante, foi discutida com insistência a questão do olhar, do seu uso e impossibilidade, de como uma imagem pode ser rica para pensar o problema da desfiguração (Taussig, 1999), neste momento pretendo ressaltar alguns outros pontos. Afirmei ter observado um trabalho de desfiguração no filme de Guerra, o qual, na última sequência, desmascara o homem, revela os olhos que durante o filme foram escondidos. Esta seria a condição de possibilidade do espaço que de agora em diante seria o espaço de fala, de revelação de uma verdade. É uma desfiguração de um rosto que foi construído durante o filme, mas é um rosto negativo desde o primeiro plano. Digo negativo porque contradiz as encenações tradicionais que valorizam o rosto como o objeto por excelência da fotogenia. Posso dizer então que é uma desfiguração do que já está desfigurado, mas isto não diz que tal deformação seja reconstrutora de um rosto e sim construtora de outro rosto, ou melhor, de um espaço.

A sobreposição dos olhares e o estranhamento que propõe o filme de Guerra, por meio das estratégias para interpelar o espectador, é um ponto a se refletir não só a partir deste filme

122 Jimeno (2010) chama à construção de comunidades emocionais, para construir uma "versão compartilhada dos acontecimentos de violência da última década [na Colômbia] e serve de alicerce para uma ética do reconhecimento e para ações de protesto e de reparação, visto que é um mediador simbólico entre a experiência subjetiva e a generalização social" (ibid., p. 99). 
como no de Stathoulopoulos. Porque, nos dois casos, as posições de voyeur e de testemunho são colocadas, isto é, estamos presentes diante de uma fala e de um ato que não são públicos: no primeiro, além de sermos perguntados se queremos ouvir, somos obrigados a ver pelo olhar do assassino; no segundo, localizamo-nos, desde o início, ao lado dos assassinos, como parte integrante e silenciosa (silenciada) do grupo. A declaração do homem da cadeira foi feita apenas para Mañe e a extorsão da família de Ofelia não deve ser contada para ninguém, sob ameaça de morte. São formas de expor e de questionar nossa relação com estas experiências, se como meros espectadores, passivos consumidores de imagens de sofrimento ou como construtores de narrativas que possam participar da desarticulação dos discursos oficiais e da prática do consumo do terror. Discurso e prática que não são outra coisa que os próprios componentes estruturadores da cultura do terror - no sentido que Taussig (1986) descreve atualmente.

Dando continuação à analise, no segundo capítulo abordei o filme $P V C$-1, produzido em 2007 e lançado três anos depois de La sombra del caminante. Um longa-metragem que coloca o espectador explicitamente no lugar do narrador, que conta um evento que não pode ser visto. A partir da observação detalhada do filme, foram discutidas as formas de elaboração audiovisual da violência com o objeto de retirar um evento do fluxo de informação das redes midiáticas e a proposta de um conhecimento venenoso e sensível.

Para tal fim foi realizada uma decoupagem minuciosa, um procedimento que foi enriquecedor porque me permitiu entender a estrutura narrativa do filme, mas, ao mesmo tempo, me colocou o problema de ter que trabalhar com um material amplo e por vezes, confuso. Por consequência, o texto desta segunda parte é fragmentado, não segue a linha temporal do filme, pois avança e recua, exatamente da mesma forma como foi processo de visualização e decupagem [play, pause, rewind, play]. A construção da análise foi feita a partir de três assuntos principais, a saber, a construção do tempo pelo plano-sequência, a posição do espectador e os limites do mostrável. Este desafio à escrita e as linhas de indagação que foram consideradas neste capítulo mostrou que o diretor investe na criação de um tempo nervoso capaz de fazer sentir e surpreender. Com isto, também pretendi expor a ideia de que a experiência do cinema é direta, sentida e, paradoxalmente, inconsciente, capaz de produzir ideias de uma forma diferente da mente. É real - pois o verdadeiro e o falso do cinema está no próprio cinema - e se torna concreto no ato e na relação entre o campo (o que é mostrado) e o 
fora-de-campo (o que não é mostrado, mas é implícito) e é, portanto, uma ação ${ }^{123}$ que tem reações.

Nesta ordem de ideias, a encenação feita por Spiros, parece responder a uma vontade de fixar na memória o ato cruel, de construir um tipo de lembrança que seja desconfortável. E convoca o público a ver e se surpreender, para não perder a sensibilidade nem a lucidez diante destes acontecimentos. No segundo capítulo, descrevi a maneira pela qual somos obrigados a ver a cena e não nos é concedida permissão de olhar para outro lugar porque a câmera (que é o espectador) segue as ações e agressões com um olhar quase clínico. Estamos presentes e não construímos a cena, podemos nos deslocar, circular, colocar as personagens no centro ou nos colocarmos no centro, mas não podemos atuar ou deter a ação. Será esta passividade imposta o que incomoda no filme? Ou o que incomoda é ser sujeitos desse conhecimento?

Não perder a capacidade de se surpreender e a construção da lembrança desconfortável resulta tanto na pergunta pela forma pertinente/possível de mostrar a angústia alheia, como na proposta de explorar outras sensibilidades, que aqui se relacionam com o choque que dura. Poderia afirmar que este filme se faz necessário, por um lado, em um tempo de revolução da linguagem fílmica do cinema colombiano e como enunciação da dificuldade que essa sociedade tem em contar sua história de violência; e, por outro, demonstra a vontade de autoconhecimento, obrigando-a a ver e contar ao construir imagens da história e com a história.

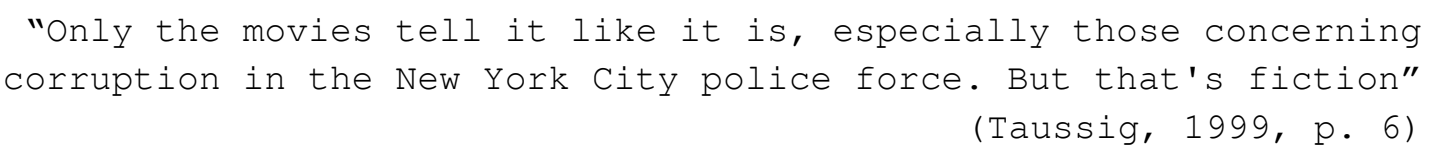

Para concluir estas considerações finais, farei uma breve reflexão sobre o indizível, pois como disse antes, é um tema que foi ganhando importância neste trabalho, primeiro como um tema a partir do qual pensei os filmes (formas de dizer o indizível), e no final como uma crítica à ideia de que existem indiziveis. Jacques Aumont ([1992] 1998) afirma que o rosto serviu como elemento de identificação no cinema, primeiro como expressividade, depois

123 Esta ideia foi apresentada pelo Professor Marcelo Prioste, no curso de extensão "Diálogos entre a filosofia, cinema e humanidades: o cinema como construção do conhecimento" na PUC-SP, em 11 de agosto de 2012 . 
como comunicação e finalmente como inexpressividade. O rosto, segundo o crítico de cinema, se relaciona com o tempo e o espaço cinematográfico e coloca questões sobre temas como a visão, a humanidade e a representabilidade. O rosto é "sagrado", diz Taussig (1999), é público e serve para se localizar diante de si mesmo e dos outros. Ele informa e ordena os tipos de relações entre o eu e o mundo, eu e a sociedade, eu e as pessoas e, deste modo, guia nossos (e os dos outros) juízos de valor sobre o outro (e os do outro sobre o si). O homem da cadeira torna inoperante tanto a identificação quanto a comunicação, mas não é inexpressivo, ele mostra muito claramente o tipo de espaço que pode/vai ocupar e de relação que pode/vai manter. Os óculos de Mañe funcionam no mesmo sentido, o que fica claro só no final, quando, depois de enterrar o corpo do homem da cadeira, tira os óculos e os guarda antes de continuar caminhando pela rua em meio à agitação da capital.

Então, a desfiguração é mais complexa do que a mera deformação e exibição do que estava escondido. $\mathrm{O}$ argumento central de Taussig gira em torno da ideia do segredo público, aquilo que é conhecido, mas que não pode ser articulado; articular o segredo não é tanto uma exposição (de uma verdade), mas é uma revelação enquanto segredo de um modo que lhe faça justiça. Uma ideia que pode ser lida já na obra de 1986: não se trata de contar o terror, mas de entender as formas de contá-lo para subvertê-lo (narrar de outra forma o que já é narrado). Taussig aproxima verdade de segredo e afirma que o menor caminho entre a violência e sua análise é o maior, o mais difícil e mais longo; uma afirmação inspirada no trabalho etnográfico que o antropólogo realizou na Colômbia, onde ninguém diz o óbvio, não porque não existam palavras, mas porque ninguém ousa fazê-lo, definitivamente, porque precisa ser dito para ser óbvio. "Todos "sabíamos" [da responsabilidade conjunta de paramilitares e militares nos massacres de camponeses], e eles "sabiam" que "sabíamos", mas não havia maneira em aquilo poderia ser facilmente articulado, certamente não no solo [ground], face-aface" (ibid., p. 6, tradução minha). E se o segredo é fundamental ao poder, o não-segredo também o é, pois reveste o problema de uma aura de mistério quase sagrada que não permite sua enunciação e sim sua justificação porque é incrível.

Didi-Huberman (2003) propõe um estudo no qual as imagens são fontes históricas. Neste texto de 2003, poeticamente titulado Images malgré tout, (imagens apesar de tudo) se vale de quatro fotografias tiradas, de forma ilícita, das câmeras de gás em Auschwitz, para pensar se estas imagens podem dizer alguma coisa dos campos de concentração, que ainda não tenha sido dita. Apesar do muito que se tem falado, escrito e filmado sobre o assunto, o 
filósofo afirma que muitos destes materiais esbarram no inefável e com isto se colocam do lado do fascismo, pois aceitariam a proposição nazista de que aquilo não aconteceu. $\mathrm{O}$ apelo feito no livro, já não é mais pela elaboração de narrativas, é para quem estuda e lê sobre estes assuntos, pois é devido escutar e acreditar, conviver com estas verdades por mais impróprias que sejam. O passo seguinte é fazê-las existir total e definitivamente no mundo.

Neste sentido, o filósofo Georges Didi-Huberman (ibid.) elabora uma ideia, que se encontra no ensaio sobre a arte de Benjamin e que Taussig adapta para propor formas de escrita dos textos na antropologia: o conhecimento pela montagem. Nos dois filmes aqui analisados, o espaço nos é apresentado em fragmentos, pois nunca temos uma visão total nem da cidade nem do povoado, o que é uma maneira de mostrar a dimensão íntima do lugar, não objetivada em mapas e ruas identificáveis. No filme de Guerra o fato de apresentar a cidade de Bogotá pelo percurso do personagem resulta em uma construção quase etnográfica desse lugar, em grande parte as notas de rodapé que interrompem a leitura do primeiro capítulo demonstram isto. Cada esquina é uma história, desperta memórias, desejos de contar cenas pessoais e biografias das personagens e dos que moram na cidade; e são espaços que vão sendo apropriados, para habitação, pelas personagens: a estátua da Pola ou o cemitério são exemplos. A cidade então é terreno de histórias, uma delas é a que o diretor escolheu contar, as outras são as que o público vê ou as que leitores deste trabalho lerão. Montagem seria uma forma de criar sentido, lugar, biografia e memória.

Estudar filmes de ficção a partir de uma perspectiva antropológica é também refletir sobre as formas de escrever, descrever e encenar nosso mundo - e não só do outro e seu mundo -, para que os conceitos sejam ampliados ou reformados, ao mesmo tempo em que aprendemos outras formas de escritura e repensamos nossas teorias e metodologias. E é, ao mesmo tempo, aprender a reconhecer e construir novas imagens, sons e textos apropriados ao nosso mundo contemporâneo, um que está deformado por violências (no plural, pois há uma grande diversidade de violências), onde ainda o passado não teve a oportunidade de se expressar plenamente pelas palavras de quem conheceu sofrimentos e torturas e onde o presente, muitas vezes, se revela devastador. 


\section{Referências}

ÁLVAREZ, Luis Alberto. Páginas de cine. Universidad de Antioquia: Medellín, 1988.

ALVAREZ, Carlos. Sobre cine colombiano y latinoamericano. Universidad Nacional de Colombia: Bogotá, 1989.

ARBOLEDA R., Paola e OSORIO, Diana Patricia. La presencia de la mujer en el cine colombiano. Ministerio de Cultura: Bogotá, 2003.

ARIAS Herrera, Juan Carlos. La vida que resiste en la imagen. Cine, política y acontecimiento. Pontificia Universidad Javeriana: Bogotá, 2010.

. "El discurso nacionalista en el cine colombiano 2005-2006" Em: Ministério de Cultura, Museo Nacional de Colombia e Fundación Patrimonio Fílmico Colombiano (orgs.). Versiones, subversiones y representaciones del cine colombiano. Investigaciones recientes. XII Cátedra Anual de Historia Ernesto Restrepo Tirado. Memorias. Museo Nacional de Colombia: Bogotá, 2008.

AUMONT, Jacques \& Alain Bergala, Michel Marie, Marc Vernet. Esthétique du film. Nathan: Paris, 1983.

. L'analyse des filmes. Nathan: Paris, 1988.

À quoi pensent les films. Séquier: Paris, 1996.

El rostro en el cine. Paidós: Barcelona, 1998.

\& MARIE, Michel. Diccionário teórico e crítico de cinema. Papirus: Campinas, [2001] 2003.

AURÉLIO. Dicionário da Língua Portuguesa. Positiva: São Paulo, 2004, 6a edição.

ARÓSTEGUI, Julio. "Violencia, sociedad y política: la definición de la violencia". Revista Ayer: Asociación de Historia contemporánea. no. 13, p. 19-55, 1994.

AYALA D., César Augusto. "Capitulo primero: Alternativas políticas al sistema bipartidista Nacional 1953- 1957". Em:___ Resistencia y oposición al establecimiento del Frente Nacional: los orígenes de la Alianza Nacional Popular, ANAPO Colombia, 1953-1964. Universidad Nacional de Colombia, Facultad de Ciencias Humanas, Departamento de Historia: Bogotá, 1996.

BARBOSA, Andréa. São Paulo: Cidade azul. Imagens da cidade construídas pelo cinema paulsta dos anos 80. Tese (doutorado)- Faculdade de Filosofia, Letras e Ciências Humanas, Universidade de São Paulo, São Paulo, 2002.

BARTHÉLEMY, Amenagual. Du réalisme au cinema. Nathan: Paris, 1997.

BAZIN, André. "Ontologie de l'image photographique" (1945) Em: . Qu'est-ce que le cinéma? Les éditions du Cerf: Paris, 1987. 
"Morte todas as tardes" (1951) Em: Xavier. Ismail (org.). A experiência do cinema. Hugo Sérgio Franco (trad. André Bazin). Graal: São Paulo, 2008.

BENJAMIN, Walter. "Experiência e pobreza" (1933). Em: Obras escolhidas I. magia, técnica, arte e política. Sérgio Paulo Rouanet (trad.)Brasiliense: São Paulo, [1985] 2010.

cit.

. "O narrador. Considerações sobre a obra de Nikolai Leskov" (1936). Em: Op.

_. "A obra de arte na era de sua reprodutibilidade técnica" (1935/1936). Em: Op.

cit.

. "Sobre o conceito da História" [1940]. Em: Op. cit.

cit.

. "O surrealismo. O último instantâneo da inteligência europeia" (1941). Em: Op.

BRUNER, Edward. "Introduction. Experience and its expressions". Em: . e

TURNER, Victor. The Anthropology of experience. University of Illinois Press: Chicago, 1986.

CAICEDO, Andrés. Ojo al cine. Selecionado e anotado por: Sando Romero e Luis Ospina. Norma: Bogotá, 2009.

CALlE, Carlos. Cine-autopsia: una exploración al cine em Colombia. Colección Concursos Literários Fondo Editorial de Caldas: Caldas, 2002.

CAMACHO, Alvaro. "El ayer y el hoy de la violencia en Colombia: continuidades y descontinuidades" Analisis político, Bogotá, n.10, maio-agosto, 1990.

CAIUBY Novaes, Sylvia. "Introdução. Imagem em foco nas ciências sociais". Em: CAIUBY et al (Orgs.). Escrituras da imagem. FAPESP, Edusp: São Paulo, 2004.

- "Imagem e Ciências Sociais - trajetória de uma relação difícil". Em: Barbosa, Andréa; Cunha, Edgar; Hikiji, Rose. (Orgs.). Imagem-Conhecimento: Antropologia, cinema e outros diálogos. Papirus: Campinas, 2009.

CASTILlEJO, Alejandro. Poética de lo Otro: Hacia Una Antropología de la Guerra, la Soledad y el Exilio Interno en Colombia. Instituto Colombiano para el Desarrollo de la Ciencia y la Técnica (Colciencias), Instituto Colombiano de Antropología e Historia (ICANH), Ministerio de la Cultura: Bogotá, 2000.

"Voces del sepulcro: terror, espacio y alteridad en la guerra colombiana". En: Desterritorialidades. Emilio Piazzini e Diego Herrera (eds.). Universidad de Antioquia: Medellín, 2005.

"Entre los intersticios de las palabras: memoria, posguerra, y educación para la paz en la Sudáfrica contemporánea" Estudios de Asia y Africa. Colegio de México, México, n.129, p. 11-37, 2006. 
."The shadows of terrorism: Bodies, specters and spaces of war." En: The invisible corner: Violence, terror and memory in Contemporary South Africa en 1986. Saarbrucken: Alemanha, Verlag VDM, 2009.

CASTRO, Beatriz. "Salavarrieta, Policarpa". Biblioteca virtual, Biblioteca Luis Ángel Arango. Disponível em: http://www.banrepcultural.org/blaavirtual/biografias/salapoli.htm. Acessado em 07/2012.

Comisión Nacional de Reparación y Reconciliación CNRR. ¿Soy una víctima? Tengo derechos. Bogotá, 2007.

Comisión Nacional sobre la Desaparición de Personas-CONADEP. Nunca Mas. Informe de la Comisión Nacional sobre la Desaparición de Personas. EUDEBA: Buenos Aires, 1984.

CORTÉS S., Catalina. "Recolecciones sonoras y visuales de escenarios de memorias de la violencia" Antipoda. Revista de Antropología y Arqueología. Facultad de ciencias sociales. Departamento de Antropología. Universidad de los Andes. Bogotá. n.9 p. $165-$ 197. Jul-Dez, 2009. Disponível em: http://antipoda.uniandes.edu.co/view.php/140/index.php?id=140. Acessado em 06/2012.

DA CUNHA, Edgar. Cinema e imaginação. A imagem do índio no cinema brasileiro dos anos 70. Tese (mestrado) - Faculdade de Filosofia, Letras e Ciências Humanas, Universidade de São Paulo, São Paulo, 1999.

. Imagens do contato. Representações da alteridade e os bororo do Mato Grosso. Tese (doutorado)- Faculdade de Filosofia, Letras e Ciências Humanas, Universidade de São Paulo, São Paulo, 2004.

DAS, Veena e KLEINMAN, Arthur. "Introduction" Em: RAMPHELE, Manphela, REYNOLDS, Pamela (eds.). Violence and subjectivity. University of California Press: Los Angeles, [1997] 2000.

DAS, Veena. "the act of witnessing. Violence, poisonouss knowledge and subjetibity". Em: Op. Cit.

DAWSEY, John. "Arqueologia da festa: quarta feira de cinzas". Interceções: revista de estudos interdisciplinares, v. 1, n. 16, p. 30-36, 2007. Rio de Janeiro: UERJ/ IFCH. Disponível http://www.agenciawad.com.br/clientes/dausp/arquivos/johndaws/principais18.pdf. Acessado em 06/2012.

DIDI-HUBERMAN, Georges. Images malgré tout. Les éditions de minuit: Paris, 2003.

ECHANDÍA C., Camilo. "El conflicto armdo colombiano em los anos 90: cambios em las estratégias y efectos ecnómicos". Revista colombiana internacional. Departamento de Ciencia política, facultad de Ciencias Sociales. Universidad de los Andes, Bogotá. 2000, n. 49-50. 
EISENSTEIN, Sergei. A forma do filme. Teresa Ottoni (trad.) Jorge Zahar: Rio de Janeiro, [1940] 2002.

FABRIS, Mariarosaria. O Neo-realismo Cinematográfico italiano: uma leitura. Edusp: São Paulo, 1996.

FELDMAN, Allan. "Violence and vision. The prostheticsand aesthetics of terror" Em: DAS, Veena et al. Op. cit.

FIGUEROA, Carol Ann. "La sombra del caminante. Opera prima de un estudiante. 'Pensaba que lo podia hacer'". Kinetoscopio, la revista para los que aman el cine. Medellín v. 14, n. 71, p. 62-65, 2004.

FORERO, Edgar. El desplazamiento forzado interno en Colombia. ACNUR: Washington, 2003.

FRANCO R., Vilma Liliana. Orden Contrainsurgente y dominación. Siglo del hombre: Bogotá, 2009.

GÓMEZ M., Diana Paola. Análisis de la imagen de victima presentada em el programa de televisión "Tiempo de la verdad". Monografia (graduação) - Departamento de Antropologia, Facultad de Ciencias Sociales, Universidad de los Andes, Bogotá, 2008.

. "Testimonios audio-visuales". Actas del X Congreso de Antropología Social. La antropología Interpelada: Nuevas configuraciones político culturales en Américalatina. Editorial de la facultad de Filosofía y Letras de la Universidad de Buenos Aires: Buenos Aires, 2011. Disponível em: http://xcaas.org.ar/actas.php. Acessado em, 05/2012.

GONZÁLEZ, Fernán E., BOLÍVAR, Ingrid J., VÁZQUEZ, Teófilo. Violencia política en Colombia. De la construcción fragmentada a la construcción del Estado. CINEP: Bogotá, 2002.

GOTT, Richard. "The fall of Marquetalia" Em: Guerrilla movements in Latin America. Thomas Nelson: London, 1970.

GUERRA, Ciro. Guión: La sombra del caminante. 2001.

GUEVARA, Ernesto. La guerra de guerrillas. Cuba, 1960. Disponível em: http://www.rlp.com.ni/files/doc/1254943533_Ernesto\%20Guevara\%20$\% 20 \mathrm{La} \% 20$ guerra\%20de\%20guerrillas.pdf. Acessado em 08/2012.

GUZMÁN, Germán, FALS Borda, Orlando, UMAÑA, Eduardo. La violencia em Colombia. Suramericana: Bogotá, 1968.

GRANADA, Soledad Ma. Caracterización y contextualización de la dinámica del desplazamiento forzado interno en Colombia 1996-2006. Documentos CERAC, n. 12, dezembro. Bogotá, 2008. 
HAMBURGER, Esther. "Violência e pobreza no cinema brasileiro recente. Reflexões sobre a ideia de espetáculo". Novos Estudos. São Paulo, n. 78, p.113-p128, Julho, 2007.

HIKIJI, Rose S. Imagem-violência. Mimesis e reflexividade em alguns filmes recentes. Tese (mestrado) - Faculdade de Filosofia, Letras e Ciências Humanas, Universidade de São Paulo, São Paulo, 1998.

Instituto Distrital de Patrimonio Cultural. Bogotá, un museo a cielo abierto. Guía de esculturas y monumentos conmemorativos em el espacio público. V.1. Alcaldía Mayor de Bogotá: Bogotá, 2008.

JARAMILLO M., Alejandra. "Nación y melancolia: litareturas de la violencia en Colombia, 1995-2005”. ARBOR. Ciencia, pensamiento y cultura. n. 724, março-abril, 2007.

JIMENO, Myriam. "Lenguaje, subjetividad y experiencias de violencia." Em: Antípoda - Revista de Antropología e Arquelogía. Facultad de Ciencias Sociales. Departamento de antropología, Bogotá. n.5, p. 169-190, Jul.- Dic. 2008. Disponível em: http://antipoda.uniandes.edu.co/view.php/70/index.php?id=70 Acessado em 02/2012.

- "Emoções e política: A vítima e a construção de comunidades emocionais". Revista Mana, Rio de Janeiro, 2010, v. 16, n. 1, p. 99- 121.

KANTARIS, Geoffrey. "El cine urbano y la tercera violencia colombiana". Em: Ministério de Cultura, Museo Nacional de Colombia e Fundación Patrimonio Fílmico Colombiano (orgs.). Versiones, subversiones y representaciones del cine colombiano. Investigaciones recientes. XII Cátedra Anual de Historia Ernesto Restrepo Tirado. Memorias. Museo Nacional de Colombia: Bogotá, 2008.

KLEINMAN, Arthur. "The violences of everyday life. The multiple forms and dynamics of social violence". Em: DAS, Veena, et al. Op. cit, 2000.

LEITE, Márcia da Silva. "Voces e imagens do morro: as favelas cariocas no cinema brasileiro. Cadernos de Antropologia e imagem. UERJ/ Núcleo de Antropologia e Imagem, Rio de Janeiro, v. 11 n. 2 p. 49-68, 2000.

Ley de Justicia y Paz (Ley 975 de 2005) Por la cual se dictan las disposiciones para la reincorporación de miembros de grupos armados organizados al margen de la ley, que contribuyan de manera efectiva a la consecución de la paz nacional y se dictan las disposiciones para los acuerdos humanitarios (pela qual se ditam as disposições para a reincorporação de membros de grupos armados organizados à margem da lei, que contribuam de maneira efetiva à consecução da paz nacional e se ditam as disposições para os acordos humanitários ). Congreso da Colômbia.

Ley de víctimas y restitución de tierras (ley1448 de 2011) Por la cual se dictan las medidas de atención, asistencia y reparación integral a las víctimas del conflicto armado interno y se dictan outras disposiciones. (Pela qual se ditam as medidas de atenção, assistência e reparação integral às vítimas do conflito armado interno e se ditam outras disposições) Congresso da Colômbia. 
LÓPEZ D., Nazly Maryith. Miradas esquivas a una nación fragmentada. Reflexiones em torno al cine silente de los años veinte y la puesta en escena de la colombianidad. Alcaldía Mayor de Bogotá, Instituto Distrital de Cultura y turismo - Cinemateca Distrital: Bogotá, 2006.

MARTÍN-BARBERO, Jesús. De los medios a las mediaciones. Comunicación, cultura hegemonía. Convenio Andrés Bello: Bogotá, [1987] 1999.

MARTÍNEZ P., Hernando. Historia del cine colombiano. Ed. Guadalupe: Bogotá, 1978.

MARÍN, Ivan. "Jorge Eliécer Gaitán”. Biblioteca virtual, Biblioteca Luis Ángel Arango. Disponível em: http://www.banrepcultural.org/blaavirtual/biografias/gaitjorg.htm. Acessado em 07/2012.

MATTIAS, Frey. "Michael Haneke" em: senses of cinema. Great directors, n. 28, outubro, 2003. Disponível em: http://www.sensesofcinema.com/2003/greatdirectors/haneke-2/. Acessado em 05/2012.

MINISTERIO DE CULTURA, Dirección de Cinematografía, Museo Nacional de Colombia, Fundación Patrimonio Fílmico Colombiano (orgs.). ¡Acción! Cine em Colombia. Bogotá, 2007.

MELO, Orlando Jorge. "Introducción a la nueva edición". Em: Colombia hoy. Perspectivas hacia el siglo XXI. Jorge Orlando Melo (Coord.). Presidencia de la República: Bogotá, 1998.

MORIN, Edgar. Le cinéma ou L'homme imaginaire. Essai d'anthropologie. Minuit: Paris, 1958.

NIELAND, Justus. "Graphic violence. Native americans and the western archive in Dead Man." In: The New Centenial Review. Indiana University, Bloomigton. vol. 1, no. 2, p. 171-200, fall, 2001.

OSORIO, Oswaldo. Comunicación, Cine Colombiano y ciudad. Editorial Universidad Pontificia Bolivariana: Medellín, 2005.

. Realidad y cine colombiano. Universidad de Antioquia: Medellín, 2010.

PALACIOS, Marco, "Proyecciones sobre escenarios de mediano y corto plazo". Trabajo realizado para la Fundación Ideas para la Paz sobre el campo político y los procesos de diálogo y negociación con las FARC y el ELN, Bogotá, 22 de marzo de 2001. Publicado parcialmente com o título, "Una radiografía de Colombia". Letras Libres, Mexico v.1 n.32, Agosto, p.33 - 38, 2001. Disponível em: http://www.letras libres.com/revista/convivio/una-radiografia-de-colombia. Acessado em $08 / 2012$.

PÉCAUT, Daniel. L'Ordre et la violence. Évolution socio-politique de la Colombie entre 1930 et 1953. EHESS: Paris, 1987.

e GONZÁLEZ, Liliana. "Presente, pasado y futuro de la violencia em 
Colombia”. Desarrollo Económico. n. 36, Jan-Mar, 1997.

As FARC. Uma guerrilha sem fins? Paz e terra: São Paulo, 2010.

PESSUTO, Kelen. O “Espelho mágico" do cinema iraniano: uma análise das performances dos "não" atores nos filmes de arte. Tese (mestrado) - Artes Cênicas, Universidade Estadual de Campinas, Campinas, 2011.

PIAULT, Marc Henry. Anthropologie et cinéma. Passage à l'image, passage par l'image. Nathan: Paris, 2000.

PIZARRO, Eduardo. "Los orígenes del movimiento armado comunista em Colombia. 1946-1966". Revista Análisis Político. IEPRI-Universidad Nacional de Colombia, Bogotá. n.7, Maio- agosto, 1989. Disponível em: http://bibliotecavirtual.clacso.org.ar/ar/libros/colombia/assets/own/analisis\%20politico \%2007.pdf. Acessado em 08/2010.

. "Las Farc-EP: ¿repliegue estratégico, debilitamiento o punto de inflexión?” Em: F. GUTIÉRREZ (Coord.). Nuestra guerra sin nombre. Transformaciones del conflicto en Colombia. UN, Norma: Bogotá, 2005.

PULECIO, Enrique. "Cine y violencia em Colombia”. Em: MEDINA, Álvaro y ZEA, Gloria (orgs.). Arte y violencia em Colombia desde 1948. Norma: Bogotá, 1999

Press Book, Pequeñas voces. 2010. disponível em: http://www.pequenasvoces.com/prensa.php. Acessado em 05/2012.

Procuraduría General de la Nación. Primero las víctimas. Criterios para la reparación integral. Víctimas individuales y grupos étnicos. Bogotá, 2007.

QUIJANO, Claudia Milena. Comitês de autodefesa no Peru e grupos paramilitares na Colômbia: dois casos de contrainsurgência armada.Tese (mestrado) - Programa de Pós-graduação em Integração da América Latina, Universidade de São Paulo, São Paulo, 2010.

RABASA, Angel e CHALK, Peter. Colombian labyrinth: the synergy of drugs and insurgency and its implications for regional stability. Rand: Santa Mónica, 2001.

RESTREPO, Patricia (ed.). Los mediometrajes de FOCINE: 10 años del cine club Universidad Central. Publicaciones Universidad Central: Bogotá, 1980.

RINCÓN, Omar. Televisión, video subjetividad. Norma: Bogotá, 2000.

ROMERO, Mauricio. Paramilitares y autodefensas 1982- 2003. IEPRI: Bogotá, 2003

SALCEDO, Silva Hernando. Crónicas del cine colombiano 1897-1950. Carlos Valencia Eds.:Bogotá, 1981.

SAMAIN, Etienne. "No fundo dos olhos: os futuros visuais da antropologia". Cadernos de Antropologia e imagem, UERJ/Núcleo de Antropologia e Imagem, Rio de Janeiro, 
v.6, n.1, 1998.

SÁNCHEZ Gómez, Gonzalo. "La violencia y la supresión de la política". Em: El mausoleo iluminado. Antología del ensayo em Colombia. TORRES Duque, Oscar (comp.) Biblioteca familiar Presidencia de la República: Bogotá, 2004. Disponível em: http://www.banrepcultural.org/blaavirtual/historia/ensayo/violen.htm. Acessado em 08/2012.

SARLO, Beatriz. Tiempo pasado. Cultura de la memoria y giro subjetivo.Una discusión. Siglo XXI eds.: Buenos Aires, 2005.

SUÁREZ, Juana. Cinembargo Colombia. Ensayos críticos sobre cine y cultura. Universidad del Valle: Cali, 2009.

TAUSSIG, Michel. Shamanism, colonialism, and the wild man. A study in terror and healing.

University of Chicago Press: Chicago e Lodres, 1986

1993.

Mimesis and alterity. A particular history of the senses. Routledge: New York,

Un gigante em convulsiones. El mundo humano como sistema nervioso em emergencia permanente. Silvia Galperín (trad.) Gedisa: Barcelona, [1992] 1995.

Defacement. Standford University Press: Standford, 1999.

TARKOVSKI, Andrei. Esculpir o tempo. Jefferson Luiz Camargo (trad.). Martins fontes: São Paulo, [1990] 2002.

THOUMI, Francisco E. "Illegal drugs in Colombia: From Illegal Economic Boom to social crisis". Anals of the American Academy of Political Science. Cross-national Drug Policy. v.582, p. 102-116, jul., 2002. Disponível em: http://www.jstor.org/stable/1049737. Acessado em 08/2012.

TURIM, Maureen. Flashbacks in film. Memory and history. Routledge: New York, 1989.

URIBE, María Victoria. "Pertinencia de la verdad em un escenario de guerra como el colombiano". Resultados da primeira fase do projeto Verdad, justicia y reconciliación para una sociedad post conflictiva en Colombia." Institut Zivik da chancelaria alemã, Fundación Social e o Instituto Pensar da Universidad Javeriana. Bogotá, 2005.

VALENCIA Goelkel, Hernando. Crónicas de cine. Cinemateca Distrital: Bogotá, 1974.

VALVERDE, Umberto. Reportaje crítico al cine colombiano. Toronuevo: Cali, 1978

VANOYE, Frances \& Anne Goliot- Lété. Ensaio sobre a análise filmica. Papirus: São Paulo, [1992] 1994.

XAVIER, Ismail. Experiência e cinema. Graal: São Paulo, [1983] 2003. 
"Terra em transe. Alegoria e agonia". Em: Alegorias do subdesenvolvimento: cinema novo, tropicalismo, cinema marginal. Brasiliense: Sâo Paulo, 1993.

. "O lugar do crime. A noção clássica de representação e a teoria do espetáculo, de Griffith a Hitchcock" Em: O olhar e a cena-Melodrama, Hollywood, Cinema novo e Nelson Rodrigues. Cosac Naify: São Paulo, 2003.

"Indagações em torno de Eduardo Coutinho e seu diálogo com a tradição moderna". Em: Catálogo da retrospectiva Diretores brasileiros - Eduardo Coutinho (cinema do encontro). Mesquita, Claudia e Saraiva, Leandro (orgs.). Centro Cultural do Banco do Brasil: São Paulo, 2003b.

O discurso cinematográfico. A opacidade e a transparência. Paz e terra: São Paulo, 2005.

. Sertão mar: Glauber Rocha e a estética da fome. Cosac Naify: São Paulo, 2007.

ŽIŽEC, Slavoj. Lacrimae rerum. Ensaios sobre cinema moderno. Isa Tavares e Ricardo Gozzi (trads.). Boitempo: São Paulo, 2009.

\section{Artigos em Jornais}

"ACNUR lanza ciclo de cine Pongámonos en sus zapatos - Desplazamiento y refugio". Pantalla Colombia, Proimágenes en Movimeinto, Bogotá, n.8, julho 08-15, 2011. Disponível

em:http://www.proimagenescolombia.com/page 2011//secciones/pantalla colombia/bre ves_plantilla.php?id_noticia=3437. Acessado em 05/2012.

"Bogotá tiene una gran deuda de cine". Periódico El tiempo, Bogotá. Seção: Cultura y entretenimiento, 8 abril 2005.

COBO Borda, Juan Gustavo. "Mito, que dio su nombre a una generación, también hablaba de cine". Ciudad Viva: EL Magazin, Bogotá, n. 54, Junho 2009.

"Con la cámara al hombro". Semana.com, Bogotá. Seção: Gente, 8 nov. 2008. Disponível em: www.semana.com. Acessado em 05/2012.

"El asesinato de Rodrigo Lara Bonilla". Semana.com, Bogotá. Seção: Especiales, 7 set. 1987. Disponível em: http://www.semana.com/especiales/asesinato-rodrigo-larabonilla/23424-3.aspx. Acessado em 05/2012.

"El crimen que partió la historia". Semana.com, Bogotá. Seção: Nación, 2 maio 2009. Disponível em: http://www.semana.com/nacion/crimen-partio-historia/123535-3.aspx. Acessado em 05/2012.

"Estadísticas de desplazamiento" verdadabierta.com, Bogotá. 9 julho, 2012. Disponível em: http://www.verdadabierta.com/component/content/article/173-estadisticas/3829- 
estadisticas-de-desplazamiento. Acessado em 07/2012.

"Estadísticas cine colombiano". Pantalla Colombia, Proimágenes En Movimiento., Bogotá. Disponível em http://www.proimagenescolombia.com/secciones/cine_colombiano/estadisticas/cine_col ombiano.php. Acessado em 08/2010.

"Familiares de víctima del collar-bomba protestan por lanzamiento de película PVC-1". Periódico El Tiempo, Bogotá. Seção: Nación, 13 nov. 2008. disponível em http://www.eltiempo.com/archivo/documento/CMS-4664451. Acessado em 05/2012

GÓMEZ, Sofía. "Un día Grecia le dio la mano a Villeta". Periódico El Tiempo, Bogotá. Seção: Cultura y entretenimiento, 22 dez. 2007. disponível em: http://www.eltiempo.com/archivo/documento/MAM-2775783. Acessado em 05/2012.

LEÓN, Juanita. "Collar de dinamita". Periódico El Tiempo, Bogotá. Seção: Otros, 21 maio 2000. disponível em http://www.eltiempo.com/archivo/documento/MAM1243296. Acessado em 12/2010.

PARRA, Martha Ligia. "Nueno mapa del cine latinoamericano". Periódico El Tiempo, Bogotá. Seção: Lecturas fin de semana, 23 jul. 2009. Disponível em: www.eltiempo.com. Acessado em 01/2011.

"Punto final". Semana.com, Bogotá. Seção: Nación, 3 set. 2011. Disponível em: http://www.semana.com/nacion/punto-final/163528-3.aspx. Acessado em 05/2012.

"PVC-1". Pantalla Colombia, Proimágenes En Movimiento, Bogotá. Disponível em http://www.proimagenescolombia.com/secciones/cine colombiano/peliculas colombian as/pelicula plantilla.php?id pelicula=1796. Acessado em 11/2010.

"PVC-1, película colombiana que recuerda el drama del collar bomba, se estrenó en Cannes". Bogotá. Seção: Cultura y entretenimiento, 22 maio 2007. Disponível em: www.eltiempo.com. Acessado em 01/2011

RINCON, Omar. "Con ese cine, mejor ver televisión" Opinión: Omar Rincon. Periódico El Tiempo, Bogotá. Seção: Gente, 25 jan. 2009. Disponível em: www.eltiempo.com. Acessado em 01/2011

"25 años sin Guillermo Cano, un crimen impune". Semana.com, Bogotá. Seção: Nación, 15 dez. 2011. Disponível em: http://www.semana.com/nacion/25-anos-guillermo-canocrimen-impune/169201-3.aspx. Acessado em 05/2012.

\section{Websites}

ACNUR. Informação geral disponível em: http://www.acnur.org/t3/portugues/informacao-geral/. Acessado em 04/2012.

ACNUR. Desplazados Internos, disponível em: http://www.acnur.org/t3/a-quienayuda/desplazados-internos/. Acessado em 04/2012. 
Alcaldía Mayor de Bogotá. Decreto 98 de 2004. disponível em: http://www.alcaldiabogota.gov.co/sisjur/normas/Norma1.jsp?i=12726\#0. Acessado em 06/2011.

Banco de la República de Colombia. El banco. História. http://www.banrep.gov.co/elbanco/hs_1.htm. Acessado em 04/2012.

Canal da CNRR-Colombia no site de videos Youtube: http://www.youtube.com/user/CNRRColombia. Acessado 05/2012

Centro Internacional para la Justicia transcicional (ICTJ) www.ictj.org. Acesso permanente.

Cinemateca Distrital de Bogotá. www.cinemateca.com.co. Acesso permanente.

Cinefagos. www.cinefagos.net. Acesso permanente.

Comisión Nacional de Reparación y Reconciliación (CNRR) www.cnrrorg.co. Acesso permanente.

Counterinsurgency. http://wikileaks.org/wiki/Counterinsurgency. Acessado em 08/2012.

DANE (Departamento Administrativo Nacional de Estadística). www.dane.gov.co. Acessado em 08/2012

É tudo verdade. http://www.etudoverdade.com.br/2012b/home.asp?lng=

FARC-EP. Fuerzas Armadas Revolucionarias de Colombia- Ejército del Pueblo. Www.farc-ep.co. Acessado em 08/2012.

Festival Cannes. http://www.festival-cannes.fr. Acessado em 02/2012.

Fundación social. www.fundacion-social.com.co. Acesso permanente.

Impunity (Short Version). Youtube.com. http://www. youtube.com/watch?v=CNKISxzkdQA Acessado em 05/12

Karamelo Producciones. www.karameloproducciones.com Acessado em 08/2012.

Memoria Historica. http://www.memoriahistorica-cnrr.org.co

Ministério de Cultura. Proimágenes em movimento. Bogotá. http://www.mincultura.gov.co/index.phpidcategoria=1154?. Acessado em 08/ 2010.

Pequeñas voces. http://www.pequenasvoces.com.

Procuraduría General de la Nación (PGN) www.procuraduria.gov.co. Acesso permanente. 
Proimágenes Colombia. Fondo mixto de Promoción Cinematográfica. www.proimagenes.com.co. Acesso permanente.

_. Estadísticas de espectadores y taquilla. Disponível em: http://www.proimagenescolombia.com/secciones/fdc/otros_documentos_fdc.php?nt=17. Acessado em 05/2011.

Quinzaine des directeurs. Entrevista Spiros Statholoupolos. http://www.quinzainerealisateurs.com/gallery.php?r=10141. Acessado em 08/2012.

RAE. Moridero. http://buscon.rae.es/draeI/SrvltConsulta?TIPO_BUS=3\&LEMA=moridero. Acessado em 05/2012.

Teatro la Candelaria. www.teatrolacandelaria.org. Acessado em 04/2011.

Verdad Abierta. www.verdadabierta.co. Acesso permanente.

7o Festival de cinema Latino Americano de São Paulo. http://www.festlatinosp.com.br/2012/filmes.html. Acessado em 07/2012.

\section{Filmografia}

Ficha técnica La Sombra del caminante.

Sombra del caminante, la. Diretor: Ciro Guerra. Ano: 2004. Roteiro: Ciro Guerra. Música: Richard Córdoba. Montaje: Ivan Wild, Ricardo Cortés. Produtor: Jaime Osorio Gómez Produção: Ciudad Lunar Producciones, Tucan Producciones Cinematográficas Ltda. Elenco: Césart Badillo- Mañe, Ignacio Prieto- Homem da cadeira, Inés PrietoDoña Marelvis, Lowin Allende- Sargento Oswaldo Jaimes, Julián Díaz, Andrés Gaitán e Diego Manzano- jovens. País: Colômbia

Ficha técnica $P V C-1$

PVC-1. Diretor: Spiros Stathoulopoulos. Ano: 2007. Roteiro: Dwight Stanbulian, Spiros Stathoulopoulos. Produção: Jason Hall, Spiros Stathoulopoulos. Elenco: Elenco: Daniel Páez- Simón, Mérida Urquía- Ofelia, Alberto Zornoza- Jairo Hurtado, Hugo PereiraBenjamín, Patricia Rueda, Andrés Mahecha, Liz Pulido- Hijos. País: Colômbia.

Abre los ojos. Diretor: Alejandro Amenábar. Ano: 1997. Roteiro: Alejandro Amenábar, Mateo Gil. Produção: Las producciones del Escorpión S.L., Soegetel, Les films Alain Sarde. País: Espanha.

Agarrando pueblo. Diretor, roteiro e produção: Carlos Mayolo e Luis Ospina. Ano: 1978. Produção: SATUPLE (Sociedad de Artistas Unidos para la Liberación Eterna). País: Colômbia. 
Bajo el cielo antioqueño. Diretor: Arturo Acevedo. Ano: 1925 Produção: Gonzalo Mejía País: Colômbia.

Buscando a Miguel. Diretor: Juan Fischer. Roteiro: Juan Fischer. Ano: 2007. Produção: Erwin Goggel. País: Colômbia.

Carne de tu carne. Diretor: Carlos Mayolo. Ano: 1983 Roteiro: Carlos Mayolo. Produção: Producciones visuales, FOCINE, Berta de Carvajal e Fernando Berón. País: Colômbia.

Colombian Dream, EL. Diretor: Felipe Aljure. Ano: 2006. Roteiro: Felipe Aljure. Produção: Cinempresa.com E.U. País: Colômbia.

Cóndores no entierran todos los días. Director: Francisco Norden. Ano: 1984. Roteiro: Francisco Norden, Antonio Montaña, Carlos José Reyes. Produção: Procine. País: Colômbia.

Confesión a Laura. Diretor: Jaime Osorio Gómez. Ano: 1991. Roteiro: Alexzandra Cardona Restrepo. Produção: FOCINE (Compañía de Fomento Cinematográfica), Méliès producciones cinematográficas, TVE (Televisión Española), ICAIC (Instituto Cubano del Arte y la Industria Cinematográfica), FNCL (Fundación del Nuevo Cine Latinoamericano). País: Colômbia.

Chircales. Direção: Martha Rodríguez e Jorge Silva. Ano: 1968. Produção: Fundación Cine Documental. País: Colômbia

Cidade de deus. Diretor: Fernando Meirelles. Ano: 2002. Roteiro: Braulio Mantovani. Baseado no romance homônimo de Paulo Lins. Produção: 02Filmes e vídeo filmes. País: Brasil.

Drama del 15 de octubre, El. Director: Vicenzo Di Domenico. Ano: 1915

Esta fue mi vereda. Director: Gonzalo Canal Ramirez. Ano: 1959. País: Colômbia.

Funny games. Diretor: Michael Haneke. Ano: 1997. Roteiro: Michael Haneke. Direção de arte: Jürgen Jürges. Produção: Wega film. País: Austria.

Gente de la Universal, la. Diretor: Felipe Aljure. Ano: 1994. Roteiro: Guillermo Calle, Felipe Aljure e Manuel Arias. Produção: Foto Club 76, IMS (Colombia), Igeldo Zine Produkzioak, Televisión Española, Euskal Media S.A. (España), Channel 4 (Inglaterra), Tehaplinhe Fi (Bulgaria). País: Colômbia.

Impunity. Diretores, roteiro, pesquisa: Hollman Morris e Juan Lozano. Ano: 2011. Produção: Isabelle Gattike, Marc Irmer. País: França, Suíça, Colômbia.

Jazz singer. Diretor: Allan Crosland. Ano: 1927 Roteiro: Alfred A. Cohn baseado no romance The day of Atonement de Samson Rapahelson. Produção: Warner Bros. País: USA.

Langosta azul, la. Diretor: Álvaro Cepeda Samudio, Enrique Grau, Luis Vicens, Gabriel García Márquez. Ano: 1954. País: Colômbia. 
Milagro de la sal, El. Diretor: Luis Moya. Ano: 1958. Produção: Cinematográfica Colombiana País: Colômbia.

Noche de los lápices, la. Diretor: Hector Oliveira. Ano: 1986. Roteiro: Hector Oliveira e Daniel Kon. Produção: Fernando Ayala. País: Argentina.

Nostalgia. Diretor: Andrei Tarkovsky. Ano: 1983. Roteiro: Andrei Tarkovsky e Tonino Guerra. Fotografía: Giuseppe Lanci. Produção: Franco Casati. País: USSR, Italia.

Nuit américaine. Diretor: François Truffaut. Ano: 1973. Roteiro: François Truffaut, Jean-Louis Richard, Suzanne Schiffman. Produção: Les films du carrosse, PECF (Paris), PJC (Rome). País: França e Roma.

Olvidados, los. Director: Luis Buñuel. Ano: 1950 Roteiro: Luis Buñuel y Luis Alcoriza. Produção: Óscar Dancigers y Jaime Menasce. País: México

Pequeñas voces. Diretores: Jairo Eduardo Carrillo e Oscar Andrade. Ano: 2010. Roteiro: Jairo Eduardo Carrillo e Oscar Andrade. Direcção de arte: Alejandra Manotas. Desenho conteitual e de personagens: Karolina Villarraga. Produção: e-nnovva, RCN Cine, Cachupedillo Cine, Jaguar taller digital S.A.. Desenhos: feitos pelas crianças desplazadas pela violência na Colômbia.

Perro come perro. Diretor: Carlos Moreno. Ano: 2008. Roteiro: Alonso Torres e Carlos Moreno. Produção: Patofeo films, Antorcha films e Dynamo capital. País: Colômbia.

Primera noche, la. Diretor: Luis Alberto Restrepo. Ano: 2003. Roteiro: Luis Alberto Restrepo e Alberto Quiroga. Produção: Congo Films e Proimágenes. País: Colômbia

Rear window. Diretor: Alfred Hitchcock. Ano: 1954. Roteiro: John Michael Hayes. Produção: Paramount Studios. País: USA>

Rodrigo D no futuro. Diretor: Victor Gaviria. Ano: 1990 Roteiro: Victor Gaviria, Angela Perez e Luis Fernando Calderón. Produção: FOCINE, Producciones Tiempos Modernos e Fotoclub 76. País: Colômbia.

Rosario Tijeras. Diretor: Emilio Mallé. Ano: 2005. Roteiro: Marcelo Figueras, baseado na novela homônima de Jorge Franco. Produção: Mathias Ehrenberg, Antonio Pérez Pérez, Gustavo Ángel. País: México, Colômbia.

Russian Ark. Diretor: Alexander Sokurov. Ano: 2002. Roteiro: Alexander Sokurov e Anatoly Nikiforov. Fotografia: Tillman Büttner. Produção: Andrei Deriaban e Andrey Deryabin. País: Russia, Finlândia, Alemanha, Dinamarca e Canada.

Sacrifício. Diretor: Andrei Tarkovsky. Ano: 1986. Roteiro: Andrei Tarkovsky. Fotografia: Arne Carlsson e Steven Nykvist. Produção: Anna-Lena Wibom. País: Suécia, Francia.

Setième continent. Diretor: Michael Haneke. Ano: 1989. Roteiro: Michael Haneke. Direção de arte: Toni Peschke. Produção: Wega film. País: Austria. 
Singing in the rain. Diretores: Stanley Donen e Gene Kelly. Ano: 1952. Produtora: MGM. País: USA.

The robe. Diretor Henry Koster Ano: 1953. Roteiro: Albert Maltz e Philip Dunne. Produção: Frank Ross. País: USA.

The rope. Diretor: Alfred Hitchcock. Ano: 1948. Roteiro: Arthur Laurents e Ben Hecht, baseado na novela de Patrick Hamilton. Fotografia: Joseph A. Valentine e William Skall. Produção: Sidney Bernstein. País: USA.

Touch of evil. Diretor: Orson Welles. Ano: 1958. Roteiro: Orson Welles, baseado na novela homonima de Whit Masterson. Fotografia: Russel Metty. Produção: Albert Zugsmith. País: USA.

Virgen de los sicarios, la. Diretor: Barbet Schroeder. Ano: 2000. Roteiro: Fernando Vallejo, baseado na novela homônima do roteirista. Produção: Tucán Producciones (Colombia), Le Studio Canal Plus, Les Films du Losange (Francia), Vértigo Films S.L., Tornasol Films (España). País: Colômbia

\section{Televisão}

¿Dónde están los muchachos de CTI?. Tiempo de la verdad. Directora: Alexandra Cardona. Ano: 2008. Produção: Karamelo producciones, Procuraduria General de la Nación (Colômbia). Série de oito capítulos, transmitida pela televisão pública. 